\title{
VOLEIBOL FEMININO: UMA ANÁLISE DA ANSIEDADE TRAÇO INFLUENCIADA PELAS FORÇAS DO PROCESSO DE EXCITAÇÃO DO SISTEMA NERVOSO
}

ALAN ALESSANDRO RODRIGUES

Dissertação apresentada à Escola de Educação Física e Esporte da Universidade de São Paulo, como requisito parcial para obtenção do grau de Mestre em Educação Fisica

ORIENTADOR: Prof. Dr. ANTONIO CARLOS SIMÕES 
Rodrigues, Alan Alessandro

Voleibol feminino: uma análise da ansiedade traço influenciada pelas forças do processo de excitação do sistema nervoso / Alan Alessandro Rodrigues. - São Paulo : [s.n.], 2001.

xi, 105p.

Dissertação (Mestrado) - Escola de Educação Física e Esporte da Universidade de São Paulo.

Orientador: Prof. Dr. Antonio Carlos Simões.

1. Voleibol 2. Psicologia do esporte I. Título. 


\section{AGRADECIMENTOS}

Estou agora, de certa forma, afortunado em ter sido privilegiado numa relação com grande variedade de pessoas que representam uma combinação de diferentes áreas de formações e diferentes culturas. $A$ todas estas pessoas que de forma impar tiveram parte neste estudo e que são literalmente inúmeras para cıtar eu agradeço.

Aos meus pais Raimundo e Carmem, pelo incentivo à bons estudos:

Ao Prof. Dr. Ld. Antonio Carlos Simões, meu orientador, por ter acreditado em meu estudo, pela dedicação e paciência com a qual conduziu não só este estudo como outros, mas também durante esses dois anos que trabalhamos juntos, sendo mais que meu orientador, tornando-se meu amigo;

Uma menção especial, entretanto, eu dedico ao Prof. Ms. Sidymar Lucato amigo pessoal, que tanto incentivou a conclusão deste trabalho, auxiliando na abertura de clareiras, quando elas não existiam;

Aos amigos que aqui fiz...

Eu não poderia deixar de expressar meus profundos agradecimentos aos membros examinadores desta dissertação;

À minha esposa Vanessa Vicente Leonardi Rodrigues pelas horas dedicadas a soluções de problemas no transcurso deste caminho;

Aos meus amigos - de coração - que sempre estão ao meu lado, de uma forma ou de outra.

Aos funcionários, que sempre auxiliaram da forma mais simpática e produtiva possivel.

À minha filha Bárbara! 


\section{SUMÁRIO}

Página

LISTA DE TABELAS

LISTA DE FIGURAS

LISTA DE ANEXOS

RESUMO

viii

ABSTRACT

INTRODUÇĀO

01

2 OBJETIVOS DO ESTUDO

03

2.1 Geral

03

2.2 Especificos

04

3 CARACTERISTICAS FUNDAMENTAIS DO PROBLEMA

04

$3.1 \quad \mathrm{O}$ jogo de voleibol

3.2 A mulher atleta

3.3 A ansiedade e sua evolução

3.4 Revisão terminológica

3.5 Ansiedade e medo

$\begin{array}{lll}\text { 3.5.1 Ansiedade e estresse } & 13\end{array}$

3.6 Influências da ansiedade no desempenho esportivo 14

3.6.1 Relação entre ansiedade e desempenho 16

3.6.1.1 Teoria do impulso 16

$\begin{array}{ll}\text { 3.6.1.2 Teoria do U-invertido } & 18\end{array}$

3.6.1.3 Teoria da função de zona ótima de estimulação 19

$\begin{array}{lll}3.7 .1 & \text { A teoria de Hipócrates } & 20\end{array}$

$\begin{array}{lll}3.7 .2 & \text { A teoria de Scheldon } & 21\end{array}$

3.7.3 A teoria das dimensões primárias de Eysenck 23 
$\begin{array}{lll}\text { 3.7.4 A tipologia de Jung } & 24\end{array}$

$\begin{array}{lll}3.7 .5 & \text { Teorias de Pavlov } & 25\end{array}$

3.8 Peculiaridades tipológicas do sistema nervoso do ser humano 29

4 JUSTIFICATIVA 33

5 HIPÓTESES ESTATISTICAS 33

6 DELIMITAÇÃO DO ESTUDO 35

$7 \quad$ METODOLOGIA $\quad 35$

$\begin{array}{lll}7.1 & \text { Sujeitos da pesquisa e amostragem } & 36\end{array}$

$\begin{array}{lll}7.2 & \text { Instrumentos de medida } & 36\end{array}$

$\begin{array}{lll}7.3 & \text { Procedimentos } & 37\end{array}$

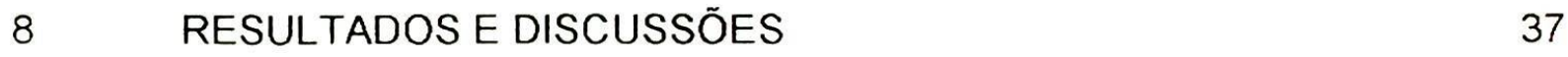

8.1 Niveis de a-traço dos sujeitos da amostra 38

8.2 Peculiaridades tipológicas do sistema nervoso dos sujeitos da $\begin{array}{ll}\text { amostra } & 40\end{array}$

8.3 Resultados da diferença entre niveis de a-traço e as peculiaridades tipológicas do sistema nervoso dos individuos $\quad 44$

9 CONCLUSÃO $\quad 54$

REFERÊNCIAS BIBLIOGRÁFICAS $\quad 56$

ANEXOS 61 


\section{LISTA DE TABELAS}

TABELA 1- Comparativo estatistico dos niveis de "a-traço" dos sujeitos da amostra

TABELA 2- Comparativo estatistico das peculiaridades tipológicas do sistema nervoso dos sujeitos da amostra

TABELA 3- Comparativo estatístico entre "a-traço" e as peculiarıdades tipológicas das atletas centrais com nivel alto, médio e baixo da força dos processos da excitação

TABELA 4- Comparativo estatístico entre "a-traço" e as peculiaridades tipológicas do das atletas de ponta, com nivel alto. médio e baixo da força dos processos da excitação

TABELA 5- Comparativo estatístico entre "a-traço" e as peculiaridades tipológicas do sistema nervoso dos sujeitos com nivel alto. médio e baixo da "FPI"

TABELA 6- Comparativo estatístico entre "a-traço" e as peculiaridades tipológicas do sistema nervoso, dos sujeitos com diferentes tipos de equilibrio (E): entre os processos da excitação e os processos da Inibição do sistema nervoso

TABELA 7- Comparativo estatístico entre "a-traço" e as peculiaridades tipológicas do sistema nervoso, com o nivel alto, médio e baixo de mobilidade (M) 


\section{LISTA DE FIGURAS}

FIGURA 1- Conceito relacional de ansiedade 11

FIGURA 2- Representação da conexão entre estresse e ansiedade 14

FIGURA 3- As inter-relações das variáveis do individuo e da situação relativas à ansiedade e ao desempenho 15

$\begin{array}{lll}\text { FIGURA 4- Diagrama da teoria do impulso } & 17\end{array}$

FIGURA 5- Teoria do U-Invertido 18

FIGURA 6- Teoria da função de zona ótima de estimulação 19

FIGURA 7- Esquematização da teoria de Hipócrates 21

FIGURA 8- As dimensões da personalidade, comparadas com as quatro categorias gregas 23

FIGURA 9- Características fundamentais do temperamento segundo Pavlov 27 


\section{LISTA DE ANEXOS}

ANEXO I - Questionário de ansiedade-traço - IDATE $\quad 61$

ANEXO II- Questionário de Strelau 63

ANEXO III- Amostra dos resultados do estudo das peculiaridades tipológicas e de a-traço

ANEXO IV- Amostra da formação dos grupos, segundo o nivel da força dos processos da excitação do sistema nervoso

ANEXO V- $\quad$ Amostra da formação dos grupos segundo o nivel da força dos processos da inibição do sistema nervoso

ANEXO VI- Amostra da formação dos grupos, segundo o nivel da mobilidade do sistema nervoso

ANEXO VII- Amostra da formação dos grupos, segundo o equilibrio entre os processos de excitação e os processos da Inibição do sistema nervoso

ANEXO VIII- Definição de termos 


\title{
RESUMO
}

\section{VOLEIBOL FEMININO: UMA ANÁLISE DA ANSIEDADE TRAÇO INFLUENCIADA PELAS FORÇAS DO PROCESSO DE EXCITAÇÃO DO SISTEMA NERVOSO}

\author{
Autor: ALAN ALESSANDRO RODRIGUES \\ Orientador: Prof. Dr. ANTONIO CARLOS SIMÕES
}

O voleibol é considerado um dos esportes que mais evoluiu nos últimos tempos, não apenas em sua forma técnica, tática e física, mas também em relação aos fatores externos que moldam suas estruturas operacionais, como por exemplo, a psicologia do esporte. O presente estudo apresentou uma pesquisa aplicada descritiva, utilizando-se de opiniões de 80 atletas de voleibol, categoria adulto, do sexo feminino. Essas atletas foram divididas em dois grupos, nos quais 40 jogadoras pertencem à posição de meio de rede, e outras 40 à posição de ponta de rede. $O$ estudo teve como objetivo verificar e comparar os niveis de ansiedade competitiva "A-Traço", quanto às suas posições especificas de ataque (ponteiras e centrais), diferenciadas pela força do processo de excitação de seu sistema nervoso, durante o torneio denominado "SuperLiga", na temporada 2001, entre as atletas da divisão especial, na faixa etária de 18 a 30 anos. Foram utilizados os instrumento de pesquisa "IDATE ", adaptado por SPIELBERGER et al. (1979) e o "STRELAU", criado por STRELAU (1984). Através de uma análise estatística do tipo paramétrica (média, desvio padrão e t-student), os resultados indicaram que quanto mais alto 0 nivel de Ansiedade Traço, menor é o nivel da Força dos Processos de Excitação do sistema nervoso das atletas de ambas as posições. Isto porque a Força dos Processos de Excitação do sistema nervoso,tem influência direta nas Peculiaridades 
Tipológicas deste sistema. Contudo, os resultados mostram que "A-Traço" pode ser considerada como uma peculiaridade principal do sistema nervosos do ser humano.

Palavras-chaves: Voleibol; Ansiedade Traço; Sistema nervoso. 


\title{
ABSTRACT
}

\section{FEMININE VOLLEYBALL: AN ANALYSIS FROM THE INFLUENCED TRAIT ANXIETY FOR THE FORCES ON THE PROCESS IN EXCITEMENT OF ITS NERVOUS SYSTEM}

\author{
Author: ALAN ALESSANDRO RODRIGUES \\ Adviser: Prof. Dr. ANTONIO CARLOS SIMÕES
}

Volleyball can be considered in the last years one of the top sports to present evolutions in terms of technique, tactics and physique as well as external factors, which design the environmental operational network like, in example, its psycho-sociology. The current study has presented a descriptive applied research based on a survey with eighty $(80)$ volleyball athletes of the feminine adult category who stated theirs opinions and support this analysis. The study was carried out by segregating the involved personnel in two (2) groups of forty (40) athletes, one group placed at left / right court forward, also called by net wing attacking, and other group placed at center court forward, also called by net middle attacking. The objective of such study is to verify and compare the level of competitive anxiety "A-Trace" (Anxiety-Trace), in terms of their court attacking position (left / right and center forward), differentiated by the excitation process force of their nervous system during the Brazilian championship denominated "SuperLiga" (used to be called by "Campeonato Brasileiro"), in 2001's season, among athletes between 18 and 30 years-old of the special division. It was used the followings resources support equipment's: "IDATE", adapted by SPILBERGER et. Al. (1979) and the questionnaire 
of "STRELAU", created by STRELAU (1984). Based on the parametric statistic analysis (average, standard deviation, and t-student), the results have indicated that how higher the "A-Trace" levels gets, lower levels of excitation process forces of the athletes' nervous system are reached, for both court positions evaluated in this analysis. This trend is explained because the excitation process forces for the human nervous system have direct influence in such system peculiar typologies. However the results indicate that "A-Trace" can be considered as a main peculiarity of the human nervous system.

Keys-word: Volleyball: Trait anxiety; Nervous System. 
O voleibol é um dos esportes coletivos que mais evoluıu no Brasil ao longo dos últimos anos. Desde a sua criação por Willian C. Morgan. essa modalidade alcançou seu ápice popular por volta dos anos oitenta, especialmente com o vice campeonato olimpico masculino de 1982, em Los Angeles/E.U.A e vice campeonato mundial masculino na Argentina, entre outros torneios femininos de expressão. como o vice- mundial em 1994. tri campeão do grand prix: 1994-1996-1998. A modalidade avançou consıderavelmente no contexto social e esportivo como um esporte coletıvo que requer todo um processo de desenvolvimento das capacidades fisicas, técnicas e táticas. além dos fatores sociais e psicológicos que norteiam o comportamento das atletas; já que as equipes, enquanto "micro-sistemas sociais de rendimento" conforme SIMÕES (1990): sofrem influência do poder maior em relação ao menor mostrando que a própria eficácia grupal depende da participação individual e coletiva.

Muito se tem feito para que os atletas obtenham um melhor desempenho. colocando-os, muitas vezes, numa situação de comprometimento para uma boa atuação: mas o que muitas vezes se ignora è o fato de que a participação em um evento atlético pode ter vários efeitos psicológicos sobre o atleta. Exemplo disso è a ansiedade competitiva, tida como um dos principais fatores influenciadores nas emoções do individuo durante a competição (DAVIDOFF, 1983), destacando-se principalmente a mulher, pois conforme MACEDO (2000, p.69), "...manifestações e caracteristicas particulares do ser feminino estão presentes nas suas ações e reações sócio-emocionais."

Essas qualidades psicológicas devem ser consideradas como parte integrante dos programas de treinamento de rendimento, especialmente aquelas que GILL \& DEETER (1988) denominam de ansiedade competitiva, considerando que o ápice da performance estaria vinculado à necessidade de rendimento cada vez maior, até mesmo em situações intensas de pressões internas e externas.

Isto representa que o voleibol feminino exige constante nivel de concentração das atletas, com diferentes niveis de "tensão/emoção", que tendem, 
conforme EAGLY \& CHAIKEN (1993), a ter um limiar de concentração inferior ao dos atletas do sexo masculino - especialmente em torno das manifestações de ansiedade competitiva, pois em todas as fases do jogo. tanto as atletas mais experientes quanto as mais jovens, atuam sob constante pressão do público. técnicos, companheiras de equipe e, principalmente, sua função na quadra: atacante de segurança, atacante de velocidade, levantadora e libero.

CRATTY (1984), destaca dois tipos de ansiedade: "A-Traço", como uma predisposição geral do comportamento da pessoa para perceber um amplo espectro de situações como perigosas ou ameaçadoras, ou seja é o nivel de ansiedade que o individuo possui naturalmente em sua conduta geral; e "A-Estado", sendo essa descrita como reações do individuo em relação às situações temporárias ou tensões circustanciais especificas na duração de um jogo ou de uma competição.

Os estudos realizados em ansiedade competitiva no voleibol, relacionada ao desempenho feminino, deixam explicito a variação da intensidade do nivel de ansiedade, de acordo com a situação, função e tipo de tarefa a ser desempenhada, podendo sofrer alta influência dos chamados "perfis de personalidade" (RODRIGUES, SIMÕES \& LUCATO, 1999, p.65). Para EVANS (1979) a ansiedade relaciona-se com o tipo de temperamento da atleta, que é definido por PETROVISKY (1985) como a combinação determinada e estável das peculiaridades psicodinâmicas, as quais se revelam em suas atividades e comportamentos, compondo sua fase orgânica; e assim também definido por NOVAIS (1977); pois o temperamento é a base da personalidade, estando intimamente ligado com os processos químicos que se operam no sistema nervoso e circulatório.

LUDIN (1977), utilizando-se das quatro categorias gregas de Hipócrates referentes ao temperamento (sangüineas, coléricas, fleumáticas e melancólicas), apresenta duas dimensões primárias de personalidade intemacionalmente reconhecidas: "introversão-extroversão", "instabilidade-estabilidade" emocional (ou neurotismo e psicotismo). Segundo SAMULSKY (1996), sujeitos instáveis e extrovertidos seriam os coléricos; sujeitos instáveis e introvertidos seriam os melancólicos, sendo que neste grupo a ansiedade é uma das caracteristicas presentes; sujeitos estáveis e introvertidos seriam os fleumáticos; e finalmente os sujeitos estáveis e extrovertidos seriam os sangüineos. 
Os estudos realızados por PAVLOV (1979) deram nova definição às quatro categorıas gregas de Hipócrates, tendo, então. consistência cıentifica conhecida e utilizável nos dias atuais; atribuindo uma proporção biológica ao temperamento do homem, visto que. os tipos de temperamentos do ser humano se desenvolvem tendo como base as peculiaridades do sistema nervoso como: a força. mobilidade e equilibrio. Portanto. CRATTY (1984) afirma que a "Força do sistema nervoso" se caracteriza pela "Força dos processo de excitação" do sistema nervoso.

Para KALININE (1994, p.67) a "Força dos Processos de Excitação" è a principal peculiaridade do sistema nervoso do homem. e tem influência nas outras peculiaridades, as quais são consideradas secundárias. KALININE (1994, p.68) descreve que individuos com baixo nivel da Força dos Processos de Excitação "FPE" - de seu sistema nervoso são mais timidos. desconfiados, muito sensiveis, e com dificuldade de adaptação. Individuos com alto nivel da "FPE" de seu sistema nervoso são mais alegres, falam alto e claro. facilmente se relacionam, são extrovertidos, e facilmente se adaptam

Através dessas citações, pode-se deduzir que "A-Traço" tem relação com as peculiaridades tipológicas do sistema nervoso, diferenciando-se quanto ao comportamento.

\section{$2.1 \quad$ Geral}

Verificar e comparar os niveis de ansiedade competitiva "A-Traço" em atletas de voleibol do sexo feminino, quanto às suas posições especificas de ataque (ponteiras e centrais), diferenciadas pela força do processo de excitação de seu sistema nervoso, durante a SuperLiga na temporada 2001, entre as atletas da divisão especial, na faixa etária de 18 a 30 anos; através dos instrumento de pesquisa "IDATE ", adaptado por SPIELBERGER, GORSUCH \& LUSHENE (1979) e "STRELAU", criado por STRELAU (1984). 


\section{$2.2 \quad$ Especificos}

1) Identificar o nivel de A-Traço dos sujeitos da amostra.

2) Identificar as peculiaridades tipológicas do sistema nervoso dos sujeitos da amostra.

3) Comparar, por posição de ataque (ponta e meio) os niveis de Ansiedade-Traço dos sujeitos da amostra.

4) Verificar a existência (ou não) de diferença entre os niveıs de A-Traço nos sujeitos de ambas as posições de ataque, diferenciados pelas peculıarıdades tipológicas de seu sistema nervoso

5) Verificar a relação da Força dos Processos de Excitação sobre outras peculiaridades tipológicas do sistema nervoso das atletas pesquisadas

\section{CARACTERISTICAS FUNDAMENTAIS DO PROBLEMA}

Inúmeros aspectos psicossociais e funcionais norteiam a capacidade de rendimento individual e coletivo de equipes, uma vez que a performance requer o uso eficaz e controlado de inteligência esportiva, às vezes, comprometido pela ansiedade competitiva "traço" ou "estado", como um inter-relacionador que interfere de forma positiva ou negativa, podendo influir decisivamente no estado emocional das atletas. Isso reforça o delineamento quanto ao processo de caracterizar o perfil competitivo das atletas de voleibol, no que diz respeito à performance de conduta, quanto às dimensões físicas e psicossociais.

Alguns autores como CRATTY (1984): SAMULSKY (1996), SIMÕES (1990) mostram que o rendimento é resultado de distintos comportamentos, os quais devem ser sistematicamente desenvolvidos, estruturados e especificamente ocultados, durante as inúmeras sessões de treinamento. A análise desses componentes facilita o reconhecimento, significado e a importancia do comprometimento de que todas as ações individuais e coletivas recaem sobre o 
comportamento grupal. Isto mostra que a ansiedade competitiva quer seja "traço" ou "estado", pode ser interpretada por distintos pontos de vista.

Conhecendo suas qualidades e suas limitações, o atleta poderá mostrar-se motivado ou ameaçado por uma situação esportiva, relacionando os recursos que ele possui com a demanda exigida, o que influenciará no seu desempenho, portanto, pretende-se com este estudo verificar as diferença entre os niveis de "A-Traço" de atletas de voleibol do sexo feminino, quanto às suas posições específicas de jogo (atacantes de ponta atacantes de meıo). diferenciadas pelas peculiaridades tipológicas de seu sistema nervoso

\section{$3.1 \quad 0$ jogo de voleibol}

O voleibol é um esporte de complexo aprendizado, e sua maior dificuldade reside no fato de envolver habilidades não naturais ou construidas. Como todo esporte, ele é baseado em gestos específicos, também chamados de fundamentos cuja diferenciação está diretamente ligada à posição ou função estabelecida dentro da quadra, pelo técnico de uma equipe.

Segundo BIZZOCCHI (2000), o voleibol pode ser classificado como um esporte de rebater ou de volear, porém, as formas comuns e naturais de rebater não podem ser transferidas para a real dinâmica de uma partida. Além dessa distinção. os fundamentos do voleibol envolvem regiões do corpo usadas eventualmente em aulas de educação física, ou na prática de outros jogos ou brincadeiras.

O jogo é constituido de seis jogadores de cada lado da quadra, separadas por uma rede que varia sua altura em função da categoria e sexo. Cada equipe normalmente, é composta por duas jogadoras que atuam no meio da rede denominadas "centrais" ou "meio de rede", responsáveis pelas bolas atacadas em velocidade e por bloquear as bolas rápidas, ou de primeiro tempo, da equipe adversária. Composta também, por jogadoras ponteiras, ponta de rede responsáveis pelo ataque e bloqueio de bolas de segurança, que normalmente decidem o jogo.

Outra posição seria a da levantadora, que coloca a bola em condições ideais para que as atacantes tenham mais facilidade de conquistar o ponto. $E$ não 
pouco importante. surgido na década de noventa, o libero, responsável pela defesa do ataque e recepção do saque. Esta posição é fixa e não se enquadra nas regras tradicionais do voleibol.

Autores como BRANDÃO (1996), RODRIGUES et al. (1999) realizaram dentro da psicologia do esporte alguns estudos a respeito do voleibol, porém. são raros, em função da grande complexidade técnica, tátıca e física que o esporte requer. Além do mais, segundo MEDVEDEV (1988), o voleibol se caracteriza por exigir determinadas características psicológicas como: auto-confiança, valentia determinação, disposição e vontade de vencer.

Outra caracteristica importante do voleibol segundo BRANDĀO (1996) è o fato de ser coletivo, e isto quer dizer que o rendimento esportivo depende dos esforços de todos os membros da equipe e, fundamentalmente. da interrelação entre os diferentes individuos que compõem a equipe esportiva.

Diz ainda que a aplicação da psicologia no voleibol pode se dar em dois momentos: o primeiro é na busca de processos psiquicos, estados psicológıcos e características de personalidade que são necessários para que ela domıne as técnicas e táticas no voleibol; e o segundo momento é na aplicação de técnıcas e estratégias para desenvolver comportamentos regulativos e autoregulativos nos treinamentos e competições, com o intúito de formar um estado de predisposıção interna, que lhe permita produzir a melhor performance possivel.

\subsection{A mulher atleta}

O esporte representa uma arena muito bem definida e visivel, onde as mulheres competem e lutam, é assim que, segundo CRATTY (1984), muitas controvérsias que cercam os êxitos das mulheres, em geral, são brilhantemente iluminadas nas arenas atléticas da América. Os esforços atléticos de uma mulher. contudo, não a marca necessariamente, como forte advogada dos direitos femininos. Ela quase sempre compete pelas mesmas razões que um homem, isto é, pela satisfação pessoal advinda do esporte.

Para MACEDO (2000), o esporte em cada sociedade é visto de diferentes maneiras, no que diz respeito ao entendimento do corpo e do comportamento social 
das mulheres. Ainda diz que, em Atenas, o processo educacional feminino estava voltado à formação moral, mental, corporal e estética. As mulheres tinham um papel social estritamente ligado à familia e sua participação no esporte as reduzia a meras espectadoras - quando isso era permitido por maridos e pais.

(...) "Verifica-se nos tempos atuais, que as mulheres têm sentimentos negativos com relação às mulheres vitoriosas, bem como, em relação ao seu próprıo sucesso, por causa dos estigmas e aprovações sociais que passaram ao longo da história" (CAMERON, 1980). Esse fator pode ser atribuido, segundo CRATTY (1984) à forma pela qual a menina foi criada, com referência às tradicionais maneiras de educar uma criança.

KANE (1970), afirma que existem várias teorias que explicam como podem as mulheres reagir em situações competitivas, entre as quais, aquelas que declaram haver diferenças de comportamento dos dois sexos desde o nascimento. e aquelas que advogam o modelo de aprendizagem social para explicar possiveis conflitos, que surgem à medida em que as mulheres começam a competir de modo mais agressivo. Em sua maioria, os estudos sobre personalidade apóiam a crença comum de que as mulheres de êxito no esporte mostram tendências dominadoras Um exame mais esclarecido das condutas femininas aventa a hipótese de que as mulheres agirão de maneiras diferenciadas, de acordo com as situações. Sua conduta poderá ser passiva e não-competitiva, ou agressiva e competitiva, conforme o que Ihes é exigido.

Para CRATTY (1984), os ritmos biológicos podem influenciar o humor: modificando a maneira pela qual a mulher encara o desempenho esportivo tensionante ou mesmo um treino, em determinada ocasião. Existem inúmeros problemas relativos à psicologia feminina nos esportes que necessitam de maiores luzes. Entre eles, citam-se os efeitos benéficos ou perniciosos da entrada precoce da menina num esporte competitivo, esporte esse que requer um treinamento vigoroso e, também, análises das forças psicológicas que recaem sobre as mulheres durante os estágios médios e finais de sua carreira. 


\section{A ansiedade e sua evolução}

Os estudos sobre a ansiedade tiveram seu inicio aproximadamente na década de sessenta, de maneira confusa. Segundo CATTELL (1975). não era conhecida a verdadeira origem e o seu significado. Os psiquiatras da época falavam de ansiedade "livre" e "encoberta" como traços que podiam apresentar-se em niveis diferentes na mesma pessoa, e ter diferentes conjuntos de manifestações. Alguns a percebiam como uma forma de medo. diluido pela incerteza ou distância do perigo. CATTELL (1975) já afirmava que ela consistia em impulsos sexuais transformados em neurose de transferência.

A literatura atual mostra a ansiedade como um sentimento de insegurança, causado por uma expectativa de perigo: ameaça ou desafio existente (CRATTY, 1984; DAVIDOFF, 1983; HACKFORT \& SCHENKMEZGER. 1993; MARTENS, VEALLEY \& BURTON, 1990). São considerados dois tipos distintos de ansiedade: ansiedade-traço (A-Traço), como uma predisposição geral de uma pessoa para perceber uma situação como ameaçadora ; e ansiedade-estado (AEstado), descrita por ser como o individuo reage a uma determinada situação. num determinado momento, interpretado por HACKFORT \& SCHENKMEZGER (1993), como sentimentos subjetivos conscientemente percebidos como inadequados, e tensão acompanhada por um aumento da estimulação do sistema nervoso autônomo. A-Estado varia em intensidade e duração, dependendo de alguns fatores como: número de estimulos de estresse que operam no individuo e a duração da ameaça subjetiva causada por estes estímulos

Na conceitualização de SPIELBERGER (1980), "A-Traço" se refere à diferenças individuais relativamente estáveis, onde a ansiedade está relacionada com uma disposição da personalidade do individuo, e "A-Estado", neste caso, se manifesta num aumento do nivel de ativação.

IZARD (1982) sustenta que a ansiedade inclui como elementos: a emoção do medo e duas ou mais dentre as emoções fundamentais, como: a vergonha, estando embutidas a culpa e timidez, a aflição, a raiva e a positiva emoção de interesse; ou seja, o excitamento em diferentes sequências e interações. Para ele, a ansiedade é uma variável e instável combinação de 
emoções fundamentais interagindo. Complementa ainda que, a ansiedade pode ser uma inteiração de forte medo,moderada aflição e leve vergonha ou culpa

Para LAZARUS (1985), a ansiedade é resultante de atos cognitivos sendo que, qualquer que seja seu conteúdo, é sempre um estado de desprazer. insegurança ou impotência, da predominância do irracional ou da perda de significações. Já para TURNER (1996), é um estado do organismo tipico de certas situações, que envolvem atividades perceptivas, fisiológicas e emocionaıs. que se traduzem em alterações características do desempenho observável.

A ansiedade é como uma apreensão deflagrada por uma ameaça a algum valor que 0 indivíduo considera essencial para a sua existência como personalidade, conforme MAY (1990, p.178). No entanto, COUOLAN (1992) a destaca como uma sensação que alguém experimenta quando imagina que algo desagradável vai acontecer, e também, que ela se comporta como uma maneira de se responder, com medo, a qualquer situação presente ou prevista, que seja percebida como ameaça potencial a auto-estima do individuo.

Todavia, para SPIELBERGER (1966), era frequentemente dificil interpretar se os investigadores estavam medindo a tendência geral de um indivíduo em ficar ansioso ou a ansiedade deste, num momento especifico e particular.

MARTENS, VEALLEY \& BURTON, (1987), cuja estrutura de definições combina com o trabalho de McGRATH (1980) e SPIELBERGER (1966), refere-se à ameaça como a percepção de desiquilibrio entre a exigência do meio ambiente $e$ a capacidade de resposta do individuo. Pode ser a percepção do perigo fisico ou psicológico.

A ameaça age como um mediador entre a exigência objetiva (estimulo) e reação de A-Estado (resposta). No entanto, MARTENS et al. (1987) relata que A-Traço é uma disposição da personalidade, afetando o desiquilíbrio percebido.

De acordo com a teoria de ansiedade Traço/Estado, os individuos de ATraço alta, percebem mais situações como ameaçadoras do que A-Traço baixa elou respodem com niveis maiores de A-Estado.

A ansiedade competitiva é uma disposição relativamente estável que reflete uma tendência individual de perceber as situações competitivas como 
ameaçadoras, MARTENS et al (1987). Até agora, as pesquisas sobre ansiedade competitiva têm se concentrado primeiramente em estabelecer sua utilidade como previsão das reações de ansiedade na competição de desportos. As pesquisas de laboratório com crianças e adultos e pesquisas de campo com participantes de esportes e atletas. consistentemente, indicam que a ansiedade competitiva alta em Individuos evidenciam maior ansiedade antes e durante a competição.

Além disso. o instrumento de medida de ansiedade traço competitiva criada por MARTENS (1977), o "SCAT" (Sport Competition Anxiety Test). foi considerado como superior à escalas gerais e avaliações dos técnıcos em prever as reações de ansiedade em competição.

Conforme SIMON (1977): os niveis de ansiedade traço competitiva em vários tipos de esportes foram examinados e categorizados ao longo de duas dimensões: individuais e coletivos. Portanto, os participantes dos esportes individuais foram mais ansiosos que os participantes de esportes coletivos, talvez como resultado do alto potencial de avaliações destes tipos de esportes. Além disso, uma interação significativa resultou com a luta greco-romana, onde o esporte de contato teve os maiores niveis de ansiedade de todos os esportes Nenhuma diferença nos niveis de ansiedade foram encontrados entre os participantes de esporte de contato. A ansiedade competitiva foi analisada por meio do "SCAT".

Também foi analisada a relação entre "A-Estado" e "A-Traço" como sugerida pela teoria da ansiedade de SPIELBERGER (1980). A previsão de AEstado pré-competitiva em várias situações esportivas foi examinada numa série de análises de regressão, em que "A-Traço" competitiva e a idade foram utilizadas como variáveis de previsão. O "SCAT" contribuiu com o maior percentual de variância para a idade, acrescentando muito pouco às previsōes. As melhores previsões foram obtidas nas situações de esportes individuais que se apresentavam mais ameaçadoras, e naquelas onde o questionário foi apresentado imediatamente antes da competição.

A literatura a respeito dos aspectos mais desenvolvidos da ansiedade tem mostrado, geralmente, que a ansiedade aumenta com a idade, encontrando seu ápice em torno dos 24 anos, se comportando a partir dessa idade de forma 
decrescente. A partir disso, optou-se, neste estudo, por trabalhar com a faıxa etária de 18 a 30 anos

HACKFORT \& SCHENKMEZGER (1993), afirmam que A-Traço pode ser visto como um conceito pessoal, ou seja, da avaliação do meı ambıente ou da tarefa como ameaçadora, sendo considerado como sensititividade; e esse à uma prontidão para reagir frente à ansiedade enfocada, podendo se caracterizar com reatividade. Para esses autores, estes conceitos variam inter individualmente e diferem intra individualmente, tendo como base os potenciais de ansiedade Para tais autores, a ansiedade tem um conceito relacional ou transacional. no qual os componentes do fator pessoal "A-Traço": se relacionam com os componentes do fator pessoal "A-Estado": interagindo com os componentes da constelação do meio ambiente e tarefa, num processo em que a Ansiedade de Estado aparece somente da inter-relação entre eles (FIGURA 1).

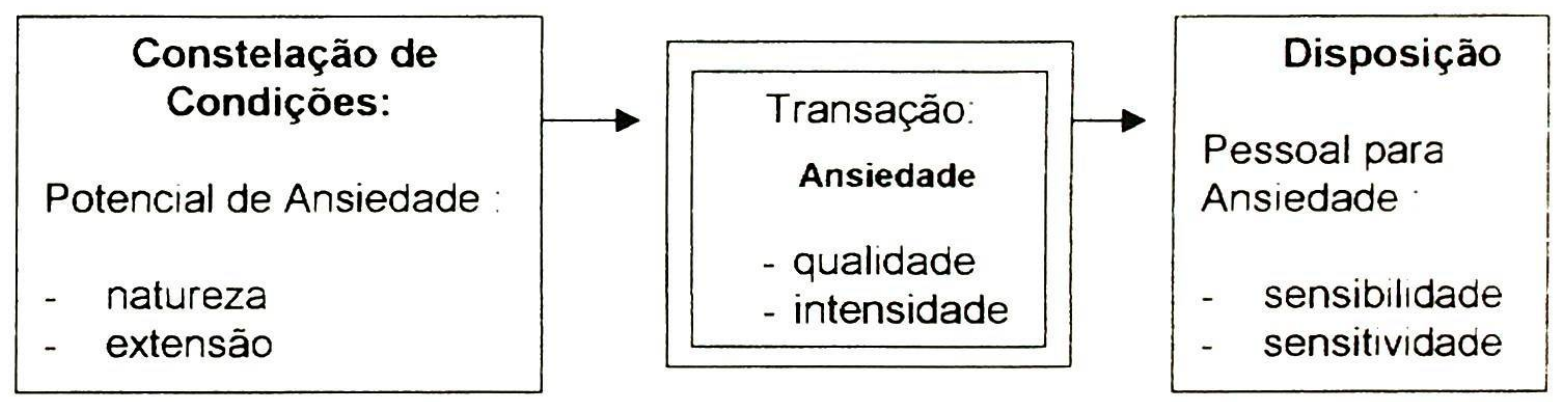

FIGURA 1-Conceito relacional de Ansiedade (HACKFORT \& SCHWENKMEZGER, 1993. p. 332).

HACKFORT \& SCHENKMEZGER (1993) enfatizam ainda que. a ansiedade resultante desta relação se difere em tipos, os quais foram chamados de "dimensões da ansiedade", sendo distinguidas as seguintes dimensōes: "ansiedade de lesão física, ansiedade de fracasso, ansiedade de competição, e ansiedade do desconhecido". 


\subsection{Revisão terminológica}

Muitos termos vêm sendo usados como sinônimos de ansiedade entre eles, tensão estresse. medo. estimulação, etc Não é raro encontrar em alguns estudos mais antigos sobre personalidades, por exemplo. o emprego de ansiedade como significado de estimulação ou estresse. tendo a denomınação empregada variando de acordo com cada pesquisador. Assim. considera-se importante neste estudo, explıcar esta questão através da literatura encontrada.

\subsection{Ansiedade e medo}

Para CATTELL (1975), estimulos concretos que sinalizam uma ameaça são frequentemente associados com o medo, enquanto que a ansiedade $\dot{e}$ atribuida à percepções que provêm somente de informações parciais baseadas em sugestões ou simbolos. Medo é uma reação incondicionada com uma função egoprotetora, um estímulo específico. A ansiedade é vista como um produto de educação e de uma experiência de aprendizagem; é causada por antecipação de processos imaginativos

No intuito de esclarecer melhor esta questão. CATTELL (1975). STEFANELLO (1990) e MACHADO (1997) salientam algumas diferenças claras de uma emoção para outra no esquema abaixo:

Medo

- Objeto claro:

- Intensidade proporcional a

Magnitude do perigo

- Ameaça a auto-estima
Ansiedade

- Objeto não claro, não real

- Intensidade menor que o medo objetivo

- Ligados diretamente aos sentimentos de bem estar físico em condições especiais 
especificas

- Temor diante de perigo real

- Dificulta o discernimento da gravidade real

- Ligada a situações dolorosas

- Exageros em situações corriqueiras que o explica

(CATTELL, 1975; MACHADO. 1997: STEFANELLO. 1990)

\subsubsection{Ansiedade e estresse}

Nenhuma distinção clara è utilizada entre os termos "Estresse" e Ansiedade". Em muitas pesquisas de campo realizadas, estes dois conceitos são tratados como sinônimos, utilizando-se, inclusive, das mesmas teorias como se fossem emoções absolutamente iguais. Dessa forma, faz-se absolutamente necessário, tentar elucidar esta questão.

JONES (1989) informou os seguintes significados para o termo

\section{"Estresse":}

- uma combinação de incentivos ou uma situação que incluı circunstâncias em que a pessoa se sente subjetivamente ameaçada e que pode causar ansiedade;

- processo que é ativado quando uma pessoa não é mais capaz de enfrentar as demandas de uma situação, e conseqüências negativas são esperadas no caso de fracasso;

- respostas para incentivos ameaçadores (HACKFORT \& SCHENKMEZGER, 1993, p.328).

Para MARTENS et al. (1990), as várias definições sobre o estresse estão geralmente ligadas com o aumento de respostas existentes a estímulos de características objetivas. Tais estimulos são chamados de estressores, podendo ser tanto de natureza física, psicológica ou de complexo social. 
HACKFORT \& SCHENKMEZGER (1993) enfatizam também alguns exemplos de estressores especificos do esporte como a reação dos espectadores; esportes de alto-risco (escalada, mergulho. corrida de automóvel): risco de dano (fracasso de uma tentativa, extremo de um esforço fisico, artes marciais): final de tempo de um jogo, mudança climática. comidas diferentes. no caso de competições em outros paises/continentes: situações conflitantes como: com o treinador os colegas, em familia/escola. ou até em decisões no curso de ações complexas no esporte.

SPIELBERGER (1979) definiu estresse como intimamente relacionado com ansiedade de estado e de traço. Ele limita o termo exclusividade para condições objetivas (estimulos) no ambiente pessoal. A avaliação individual, subjetiva destes estimulos (ou incentivos) como ameaça física ou psicológica. é caracterizada pelo termo "ameaça". Uma pessoa com alta ansiedade-traço tem tendência a perceber muitas condições (mais condições que uma pessoa com baixa ansiedade-traço), como ameaçadoras e responder com asiendade-estado. conforme FIGURA 2.

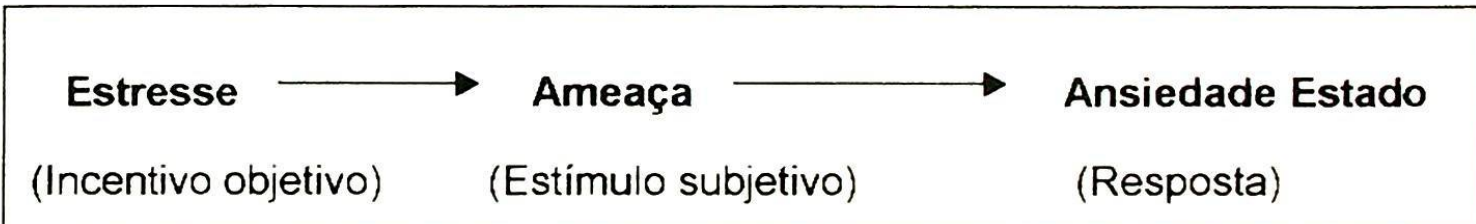

FIGURA 2 - Representação da conexão entre estresse e ansiedade de acordo com SPIELBERGER (1979, p.331).

Entretanto, deve ficar claro que, até os dias atuais, ainda não existe uma aceitação generalizada pela comunidade cientifica sobre um ou outro conceito de distinção entre estresse e ansiedade.

\subsection{Influências da ansiedade no desempenho esportivo}

MAGILL (1984) diz que a relação entre ansiedade e desempenho indicam que os niveis de ansiedade-estado que uma pessoa exibirá não estão 
exclusivamente ligados ao nivel da ansiedade-traço deste mesmo individuo Este autor salienta que a "situação" e a "tarefa" são doıs fatores importantes. e devem ser considerados

Em relação à situação, há duas variáveis que interagem com o nivel de ansiedade-traço do indivíduo, estas são: a importância da situação para o ındividuo e a incerteza do resultado da situação. No primeiro caso quanto maior a importância que a pessoa confere à determinada situação (um campeonato um jogo cobrança de uma penalidade etc.). maiores serão os niveıs de ansıedadeestado que esta pessoa apresentará. Claro que, se um ındıviduo possui niveıs maıs altos de ansiedade-estado, maior será a probabilidade de que ele apresente niveıs mais altos de ansiedade-estado. No segundo caso, para melhor compreensão. pode-se utilizar o seguinte exemplo: num jogo em que os adversárıos se equivalem e a pontuação é "parelha", provavelmente, elevar-se-á o nivel de ansiedade-estado dos jogadores. MAGILL (1984) salienta ainda que, essas duas variáveıs da situação devem ser consideradas como dependentes, já que. interagem juntamente na "A-Traço" produzindo um determinado nivel de "A-Estado"

Em relação à tarefa, deve ser considerada sua complexıdade e dificuldade Neste caso, segundo MAGILL (1984). uma tarefa mais complexa será desempenhada com mais dificuldade pelo atleta do que a menos complexa. por mais habilidoso que tal atleta seja, conforme a FIGURA 3.

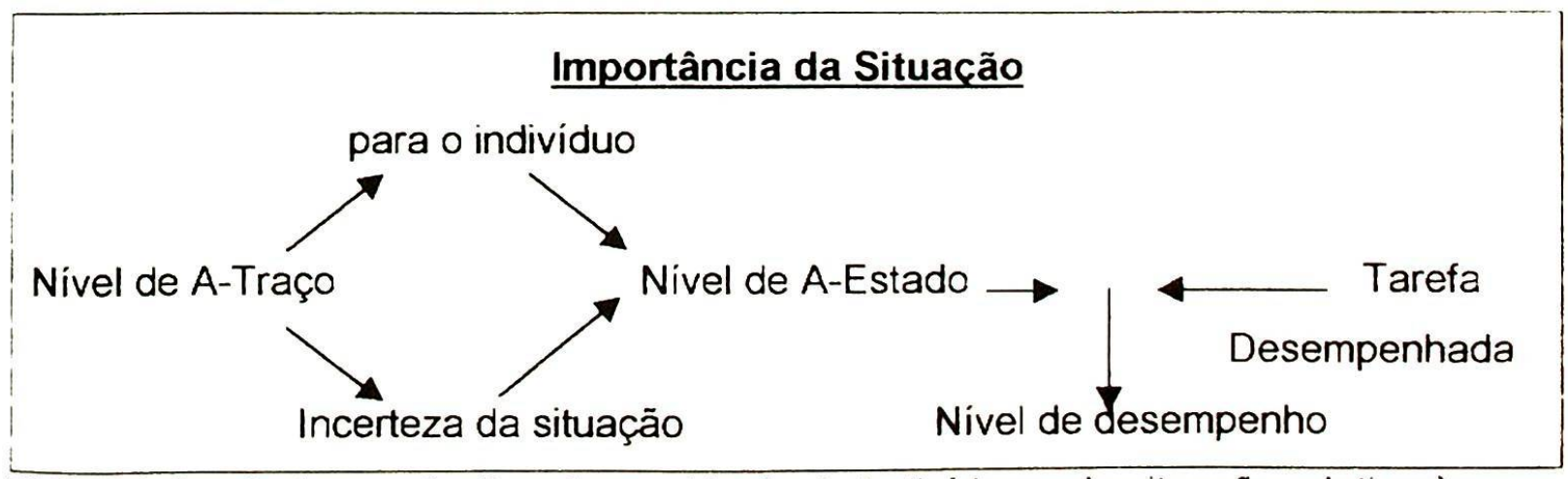

FIGURA 3 - As inter-relações das variáveis do individuo e da situação relativa à Ansiedade e ao desempenho. Fonte: MAGILL (1984, p.246). 
Para CRATTY (1984). o surgımento da ansiedade no periodo competitıvo e sua influência no desempenho também acontecem pela relação com outros fatores, que devem ser considerados. Estes fatores são: os aspectos temporais: a influência na capacidade de atenção; o surgimento de tensão psiquica e cansaço/tensão muscular; e temores do atleta antes da competição (temor de fracasso. exigência indiscutivel da vitória, rejeição do técnico, medo de agressões temor à dor). Estudo realizado (SIMON, 1977) mostra que a natureza do esporte também pode influenciar a resposta de A-Estado. Neste estudo observou-se que a ansiedade prè-competitiva é mais alta em atletas de esporte individual do que em atletas de esporte coletivo. RODRIGUES at al. (1999) discutem que esta ansiedade é maior nas mulheres do que nos homens, quando fez a comparação entre atletas de sexos diferentes no voleibol de alto rendimento

\subsubsection{Relação entre ansiedade e desempenho}

A influência da ansiedade no desempenho é o principal foco das pesquisas atuais da área, dessa forma, surgiram várias teorias que tentam explıcar este processo. Neste trabalho estão relatadas as teorias consideradas, na literatura existente, como as mais influentes e conhecidas.

Porém, faz-se necessário, neste tópico, ressaltar o fato de que tais teorias foram criadas com base em pesquisas que objetivaram o fator "ativação", sendo ainda que muito destes estudos foram realizados em animais, e tiveram o resultado transferido para seres humanos. Com o passar do tempo, utilizou-se indivíduos como amostras de tais, pois, acredita-se que o processo de ansiedade ocorre da mesma forma que o da ativação.

\subsubsection{Teoria do impulso}

Segundo CRATTY (1984), a Teoria do Impulso se destacou na tentativa de explicar o processo da ansiedade e performance; Esta teoria sugere que existe 
uma relação linear entre ansiedade estado e desempenho. ou seja. quanto maior a ansiedade de estado, maior será o nivel de desempenho do individuo sendo que o mesmo acontece no processo contrário. como visto na FIGURA 4

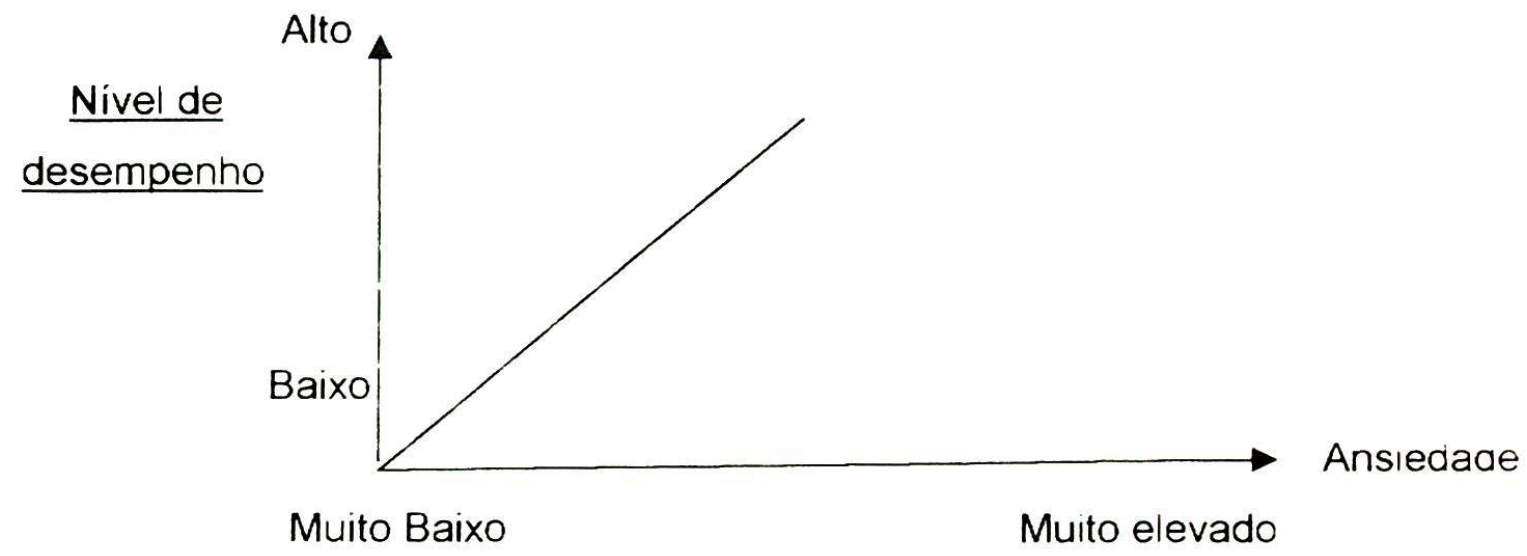

FIGURA 4 - Diagrama da teoria do impulso (MAGILL. 1984 p.245).

Em resumo esta teoria se baseia na seguinte fórmula: $B=f(D \times H)$ onde (B) significa a "força de um comportamento especifico". Este comportamento è uma função da situação de efetivo impulso (D) e a força do hábito $(H)$ O estado do impulso é considerado um construção hipotética e definida como a soma de todos os componentes energéticos que afetam o comportamento individual. D é conectado multiplicativamente com a força de hábito. Um hábito é uma seqüência relativamente automática de reações, principalmente motoras. O constructo hipotético "força do hábito" representa a intensidade da tendência à uma reação especifica para seguir um certo estímulo

A "Teoria do Impulso é dependente de uma reação emocional, a qual é causada por um estimulo aversivo, havendo, entretanto, diferenças individuais na força de tal reação emocional, neste caso: a ansiedade." (HACKFORT \& SCHENKMEZGER, 1993, p.67).

Em estudos realizados por HACKFORT \& SCHENKMEZGER (1993) com o objetivo de rever esta teoria, incluem somente trabalhos que se utilizaram da "Manifest Anxiety Scale" (MAS), (TAYLOR, 1953, p.88). Para operacionalizar os niveis de ansiedade, foi possivel observar que individuos com alto nivel de ansiedade têm efetivamente melhor desempenho em tarefas motoras. 
Contudo. ao considerar-se a freqüência de erros poucos dos estudos revisados mostraram resultados que se adaptavam com a teoria

MAGILL (1984) salienta que uma das desvantagens desta teoria é não se adequar na previsão precisa de seus efeitos em tarefas motoras. Dessa forma HACKFORT \& SCHENKMEZGER (1993) resumiram vários estudos e observaram que estes não satisfazem aos padrões metodológicos. Essa questão também é enfatizada por CRATTY (1984, p.53). que atribui a este "modelo" uma "visão simplista desde o inicio deste século, pois, suas raizes se encontram nos primeiros estudos (que geralmente empregavam animais) da psicologia experimental".

\subsubsection{Teoria do U-invertido}

Segundo CRATTY (1984), as discussões estabelecidas em torno da questão ansiedade e desempenho, postularam na chamada "hipótese do UInvertido", a qual segue a lei de ativação. Esta teoria pode ser uma alternativa para a Teoria do Impulso de Hull, pois o melhor desempenho é produzido por um "nivel ótimo" de ansiedade. Dessa forma, traçou-se um gráfico, no qual a curva é postulada em forma de um $U$ invertido, sugerindo que o nivel ótimo é uma medida mediana, ou seja, niveis muito altos ou muito baixos são prejudiciais ao desempenho.

Para explicar melhor esta questão, MAGILL (1984) cita o seguinte exemplo: "a posição de um homem de defesa (defensive tackle) no futebol americano é tão difícil quanto a do homem de meio de campo (quarterback). Mas, em vista de niveis de ansiedade, pode-se prever que um "defensive tackle" terá desempenho melhor com niveis muito mais altos de ansiedade que um "quarterback".

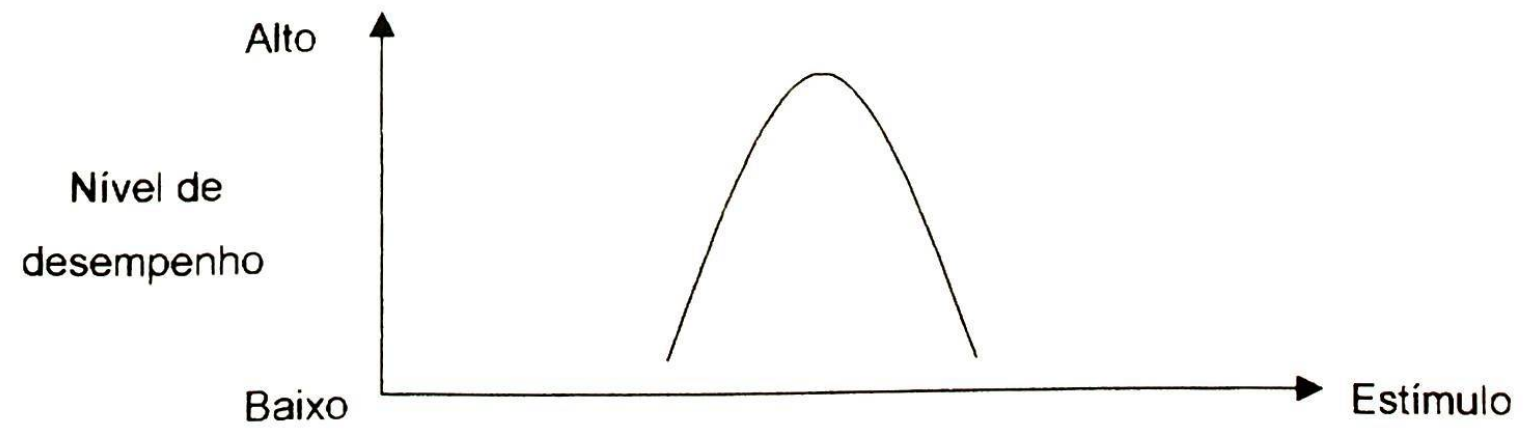

FIGURA 5 - Teoria do U-Invertido (Cratty, 1984 p.131). 


\subsubsection{Teoria da função de zona ótima de estimulação}

A teoria da Função da Zona Ótima de Estimulação (ZOF), defendida por Hanin está baseada no pressuposto de que existe um nivel ótimo de ansiedade. (também aplicada a ativação), para cada individuo, podendo ser este nivel baixo, alto ou ainda moderado: ou seja. alguns individuos melhoram seu desempenho quando o nivel de ativação está alto, outros com nivel baixo e outros ainda, com nivel moderado. HACKFORT \& SCHENKMEZGER (1993) realizaram estudos com nadadores de longa distância, podendo observar que um mesmo nivel de ansiedade foi associado com alto desempenho em alguns atletas e com baixo desempenho em outros.

Para CRATTY (1984). esta teoria, confirma a hipótese de que há um nivel ótimo de ativação que se diferencia de acordo com a modalidade esportıva e de acordo com a situação, requerendo diversos niveis de estimulação. Além disso, o nivel ótimo de ansiedade está diretamente relacionado com as diferenças individuais pois HACKFORT \& SCHENKMEZGER (1993) enfatizam que os niveis de ansiedade variam entre individuos, dependendo da interpretação subjetiva de cada um, em relação a realidade da situação. Para SAMULSKI, (1996) o conceito de ansiedadetraço refere-se à diferenças individuais relativamente estáveis relacionadas com ansiedade, como uma disposição ou traço (trait) da personalidade; e a ansiedade de estado manifesta-se num aumento do nivel de ativação. Tal situação. conseqüentemente, relaciona o nivel de ansiedade para cada sujeito de acordo com suas peculiaridades tipológicas, conforme a FIGURA 6.

Nivel de desempenho

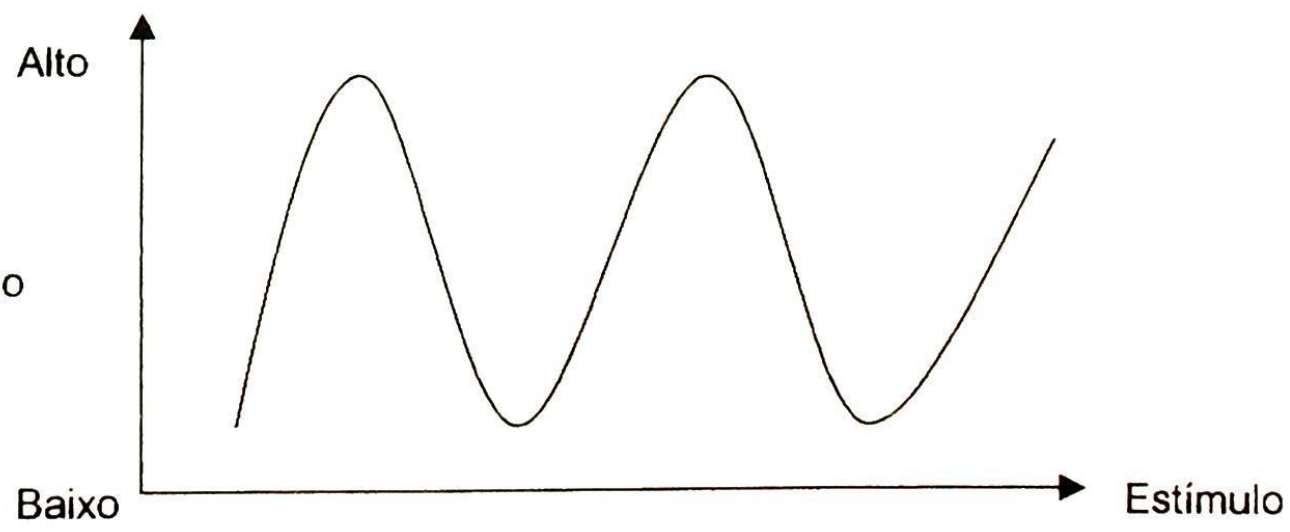

FIGURA 6 - Teoria da função de zona ótima de estimulação (MAGILL, 1984 p. 143). 


\subsection{Conseqüências da ansiedade}

Com a persistência da ansiedade e com vários estimulos que provocam processo. as conseqüências são variadas e graves. "Nas manifestações comportamentais de ansiedade há interferência no sono. as relações interpessoais tornam-se delicadas, e ainda, podem provocar doenças chamadas "psicossomáticas", como por exemplo úlceras gástricas dıstúrbıos cardiacos. hipertensão arterial doenças da pele e distúrbios respiratórios como. febre do feno e asma. Estas doenças são frequentemente interpretadas como conseqüêncıas das respostas de ansiedade, porém, na medida, em que a ansiedade se generalıza elas também se tornam crônicas." (LUDIN, 1977, p.121).

\subsubsection{A teoria de Hipócrates}

A teoria do temperamento de Hipócrates é a mais antiga de que se tem conhecimento. $\dot{E}$ também a que mais influenciou os estudos que se desenvolveram neste campo. Segundo ALLPORT (1969), a antiga crença grega atribuida por Empédocles do século $\mathrm{V}$ a. $\mathrm{C}$., de que toda a natureza é composta de quatro elementos, os quais são: ar: terra, fogo e água (o macrocosmo). serviu como pressuposto para Hipócrates: o "pai da medicina", na formulação de sua teoria. Ele acreditava que essa fórmula da natureza, (os elementos ar, terra, fogo e água ). refletiam na constituição do homem, (o microcosmo), sendo representados no corpo humano, sob a forma de quatro "humores". No caso de um humor predominar no corpo, deveria-se esperar a predominância de um tipo de temperamento.

LUDIN (1977) cita que Hipócrates dividiu os "humores" em quatro classificações, sendo: bilis preta, sangue; bilis amarela; e fleugma. Os individuos que tivessem a predominância da bilis preta, teriam um temperamento "melancólico"; os que tivessem o predominio do sangue, teriam temperamento "sangüineo" predominância da bilis amarela, teriam temperamento colérico e no predominio do fleugma, teriam o temperamento "fleumático". No século II da era cristã, essa teoria recebeu contribuiçōes do médico romano Galeno. Segundo ALLPORT (1969), Galeno observou que os "humores" poderiam ser não só a base do temperamento, 
mas também das doenças. Por exemplo, um excesso de bilıs amarela poderıa causa: febre e excesso de bilis negra depressão. A FIGURA 07 mostra claramente o relacionamento entre os elementos. suas caracteristicas, os "humores" e os temperamentos

\section{Humores Correspondentes Temperamentos Correspondentes}

\author{
Sangue \\ bilis negra \\ bilis amarela \\ fleugma
}

sangüineo

melancólico

colérico

fleumático

FIGURA 7- Esquematização da Teoria de Hipócrates, ALLPORT (1969. p 60)

\subsubsection{A Teoria de Scheldon}

Esta teoria é mais recente. LORENZINI (1958), supõe que existe relação entre as estruturas corporais e o temperamento do individuo. sendo tals fatores considerados matérias primas com "força" emparelhadas. a partir das quals, em parte, forma-se a personalidade através da aprendizagem Segundo ALLPORT (1969). Scheldon ultilizou-se de fotografias de milhares de estudantes universitárıs identificando-os com base em três tipos de constituiçōes morfológicas Posteriormente. estes tipos foram escalonados em um continuo de 1 a 7 . em vez de serem classificados em uma ou outra categoria. Segundo LORENZINI (1958), tais tipos foram chamados de "endomorfia, mesomorfia e ectomorfia". (os quais correspondem perfeitamente aos tipos pícnico, atlético e astênico), onde o primeiro tinha maior desenvolvimento visceral e do trato digestivo, tendendo assim a ser pequeno e gordo na sua forma externa. O segundo, caracterizava-se por predominıo dos ossos e músculos, sendo, por isso, forte e vigoroso. Finalmente, o terceiro, que se caracterizava por serem altos, de traços frágeis e estrutura esguia, tendo músculos poucos desenvolvidos 
LORENZINI (1958) afirma que foi tomado como base para conceitualização dos tıpos (endomorfo. mesoformo e ectomorfo) com as três folhas do blastoderma (camadas germinativas) do embrião, as quais são: ectoderma endoderma e mesoderma acrescida pelo mesênquima Dessa forma, os tipos somáticos resultarıam do desenvolvimento maior de uma ou de outra folha do blastoderma. Por exemplo o tipo "mesoformo", que se caracteriza pelo alto desenvolvimento da musculatura e ossos fortalecidos, teriam sua origem na folna do mesoderma, a qual é ıntermediárıa ao embrião e responsável pelo desenvolvımento dos ossos músculos, tecido conjuntivo, coração, etc.

Nesta teoria, o pesquisador classificava cada indıviduo em um desses tipos, usando a escala de 1 a 7 . Por exemplo, o endomorfo mais extremo poderia ser representado por 7-1-1. o mesomorfo mais extremo por 1-7-1 e o ectomorfo mais extremo por 1-1-7, sendo que a maioria dos individuos se encontrariam flutuantes entre um ou outro tipo e seriam poucos os encontrados em suas formas puras. Por exemplo, o individuo predominantemente mesoformo que mostra alguma caracteristica endomórfica e nenhuma ectomorfia seria classificado como 2-6-1

De acordo com esses três tipos fisicos, o pesquisador atribui três dimensões do temperamento "viscerotonia, somatotonia e cerebrotonia". A primeira se caracteriza por descontração e disposição extrovertida, estando altamente relacionada com a endomorfia. A segunda, caracterizada por grande potencial energético ativo e agressivo. correlacionando-se com a mesomorfia. A terceira, teria como base traços de inibição, repressão e retraimento, se relacionando com a ectomorfia. ALLPORT (1969) enfatiza ainda que, os estudos de SHELDON (1940) mostram alta correlação entre os tipos de corpo (somatótipos) e as características do temperamento

SHELDON (1940) foi fortemente influenciado pela teoria citada por ALLPORT (1969), porém, com uma concepção mais científica, utilizando-se primeiramente, das fotografias em lugar da observação e identificando três tipos de constituições formulados através da reunião de traços encontrados na literatura. Posteriormente, escalonou-os em um continuo de 1 a 7 , ao invés de serem, simplesmente, classificados em uma ou outra categoria. 


\subsubsection{A Teoria das dimensões primárias de Eysenck}

O pesquisador britânico EYSENCK (1969) utilizando-se da análise fatorial, baseava-se em "traços e tipos de personalidade" para melhor estudar o individuo. Dessa forma, identificou o que segundo ele seria as duas dimensōes primárias da personalidade introversão - extroversão: instabilıdade (neurotısmo) estabilidade emocional (psicotismo). Tal conceito de personalidade internacionalmente reconhecido, relaciona-se também com as quatro categorias gregas, já citadas anterıormente. conforme ilustrado na FIGURA 8

\begin{tabular}{|c|c|c|c|}
\hline \multicolumn{4}{|c|}{ Instável } \\
\hline \multicolumn{2}{|c|}{ Rigido } & \multicolumn{2}{|r|}{ Agressivo } \\
\hline \multicolumn{2}{|l|}{ Sério } & \multicolumn{2}{|r|}{ Excitado } \\
\hline \multicolumn{2}{|c|}{ Pessimista } & \multicolumn{2}{|r|}{ Alterável } \\
\hline \multicolumn{2}{|c|}{ Reservado } & \multicolumn{2}{|r|}{ Impulsivo } \\
\hline Insociável & Melancólıco & Colérico & Otımista \\
\hline Quieto & & & Ativo \\
\hline \multicolumn{4}{|l|}{ Introvertido } \\
\hline Passivo & & & Sociável \\
\hline Cuidadoso & Fleumático & Sanguineo & Expressivo \\
\hline \multicolumn{2}{|l|}{ Pensativo } & \multicolumn{2}{|r|}{ Falante } \\
\hline \multicolumn{2}{|c|}{ Pacifico } & \multicolumn{2}{|r|}{ Responsável } \\
\hline \multicolumn{2}{|c|}{ Controlado } & \multicolumn{2}{|r|}{ Expansivel } \\
\hline \multicolumn{2}{|c|}{ Realista } & \multicolumn{2}{|r|}{ Lider } \\
\hline \multicolumn{2}{|c|}{ Calmo } & \multicolumn{2}{|c|}{ "Dá respostas" } \\
\hline & & & \\
\hline
\end{tabular}

FIGURA 8- As dimensões da personalidade comparadas com as quatro categorias gregas (adaptado de EYSENCK. 1969, p. 78).

EYSENCK (1969) descreve que, no primeiro passo para construção de sua teoria, foram estabelecidas as dimensões principais (emotividade e extroversão). 
"... o passo seguinte foı, é claro mostrar descritıvamente e por meio estudos experimentais. exatamente como estas duas dimensões foram constituidas que traços pertecem a cada uma Então, fizemos um grande número de estudos a maioria de tipos descritivo, pegando introvertidos e extrovertidos, para ver como eles diferiam numa grande variedade de testes experimentaıs. e chegamos a entender melhor a natureza da dimensão extroversão-introversão. Inıcialmente, pensei estar em posição de levantar uma hipótese quanto a natureza subjacente. psicológıcafisiológica, desta dimensão. sendo a melhor hipótese a seguınte: que os extrovertidos são caracterizados por uma excitação cortical. Agora acho que a teorıa tem sıdo provada" (EVANS. 1979.p.305).

Em sua teoria. EYSENCK (1969), evidencia bases biológicas para as tipologias "extroversão e introversão" da seguinte forma: os introvertidos se caracterizam por alta estimulação cortical, o que faz com que estes formem melhores respostas condicionadas e, segundo o autor, as respostas condicionadas são em parte responsáveis pela produção de desordens neuróticas pois estas são respostas emocionais condicionadas Consequentemente os introvertidos podem provavelmente, ser mais encontrados entre os neuróticos. Já com os extrovertidos. o processo é inverso ou seja, estes condicionam muito pouco, porém, o comportamento socializado. segundo o autor, se deve largamente à respostas condicionadas que adquirimos, sob o pretexto de consciência, quando crianças; por conseguinte, os extrovertidos, podem ser encontrados com padrões de comportamento, talvez não muito aceitos pela sociedade.(EVANS, 1979, p.201).

\subsubsection{A Tipologia de Jung}

LAZARUS (1979) nos traz grande contribuição ao citar os estudos de Carlos Gustavo Jung, médico psiquiatra que trabalhava com enfermidades nervosas e considerava a extroversão e introversão como amplas categorias, definindo, para melhor entendimento, o extrovertido como: primordialmente orientado para os outros e para o mundo exterior. E o introvertido, mais preocupado consigo próprio e com o mundo subjetivo. 
Para esse médıco, "introvertidos são indıviduos altamente reflexıvos escassamente habilidosos nas atividades externas, ou melhor, pouco preparados para enfrentar as dificuldades da vida: são tímidos, encerrados em si mesmos e poucos expansivos. Os extrovertidos representam a tendência contrárı́ são sujeitos mais inclinados para o exterior, para o dinamismo prático e pouco para a vida intıma são tipos expansivos, utilitários e hábeis". ( LORENZINI, 1958 p.99).

Considera-se ainda que, a extroversão e a introversão exprimem-se numa série de funções. Incluindo o pensar, o sentir. o perceber e o intuir. LAZARUS (1979) enfatiza ainda que, esta tipologia è mais complexa do que é usualmente entendido por exemplo. "um individuo pode ser extrovertido na atıvidade pensante mas um introvertido na função intuitiva". Dessa forma. Jung apresenta oito tıpos sendo quatro tipos extrovertidos e quatro tipos introvertidos ( LORENZINI. 1958, p. 100):

1. Extrovertido intelectual

2. Extrovertido sentimental

3. Extrovertido sensorial

4. Extrovertido intuitivo
Introvertido intelectual Introvertido sentımental Introvertido sensorial Introvertido intuitıvo

No esporte. as diferenças entre extrovertidos e introvertidos também foram estudadas. como a de KANE (1970), onde afirma que os sprinters e os lançadores são mais extrovertidos do que os atletas de meio fundo. Parece que introversão aumenta à medida em que a distância aumenta, pois, os corredores de maratona são, na sua maioria, introvertidos. Para SAMULSKI (1996), os esportistas de modalidades individuais tendem mais a introversão: são menos motivados para contatos sociais, têm um nivel maior de agressividade, parecem mais criativos do que os esportivas de modalidades coletivas, os quais tendem mais para a extroversão.

\subsubsection{Teorias de Pavlov}

As quatro categorias temperamentais de Hipócrates tornaram-se conhecidas em todo o mundo científico, porém, com o passar dos anos, alguns 
estudiosos reconstruiram as definições de cada tipo, aprofundando-se em bases cientificas. O precursor destes estudos, foi PAVLOV (1979, p.99), que ainda diz

\begin{abstract}
"O estudo dos reflexos condicionados num grande número de cães fez surgir, pouco a pouco, a questão da diversıdade dos sistemas nervosos em animais diferentes, e, finalmente. obtivemos desses estudos. dados suficientes para classificar os sistemas nervosos, segundo as suas caracteristicas fundamentais .
\end{abstract}

Tais características podem ser classificadas como

1- Força dos processos nervosos fundamentais (Excitação e Inibição)

2- Equilibrio destes processos;

3- Mobilidade destes processos.

Segundo PAVLOV (1979): estas caracteristicas são semelhantes tanto nos animais como nos seres humanos, sendo que, a combinação real destas três peculiaridades constituem quatro tipos, mais ou menos nitidos, de sistemas nervosos, de acordo com a intensidade destes processos: o sistema nervoso pode ser forte ou fraco. Os fortes, por sua vez, se dividem, conforme o equilibrio dos seus processos, em Sistema Nervoso equilibrado e Sistema Nervoso desequilibrado : os que são equilibrados e fortes se dividem conforme a mobilidade ou a inércia dos seus processos. Dessa forma, é possivel dizer que há, seres humanos com sistema nervoso forte, mas não equilibrados, nos quais dois processos são poderosos, e a excitação predomina sobre a inibição - são os coléricos, segundo LAZARUS (1979). tipo excitável e impulsivo. Os individuos com o tipo de sistema nervoso forte. equilibrados, mas inertes, calmos e lentos são os fleumáticos. Em seguida o tıpo forte, bem equilibrado, hábil muito vivo e móvel são os sangüineos. $E$ finalmente os individuos que apresentam um tipo fraco, de sistema nervoso, que correspondem muito bem aos melancólicos. Ver FIGURA 9. 


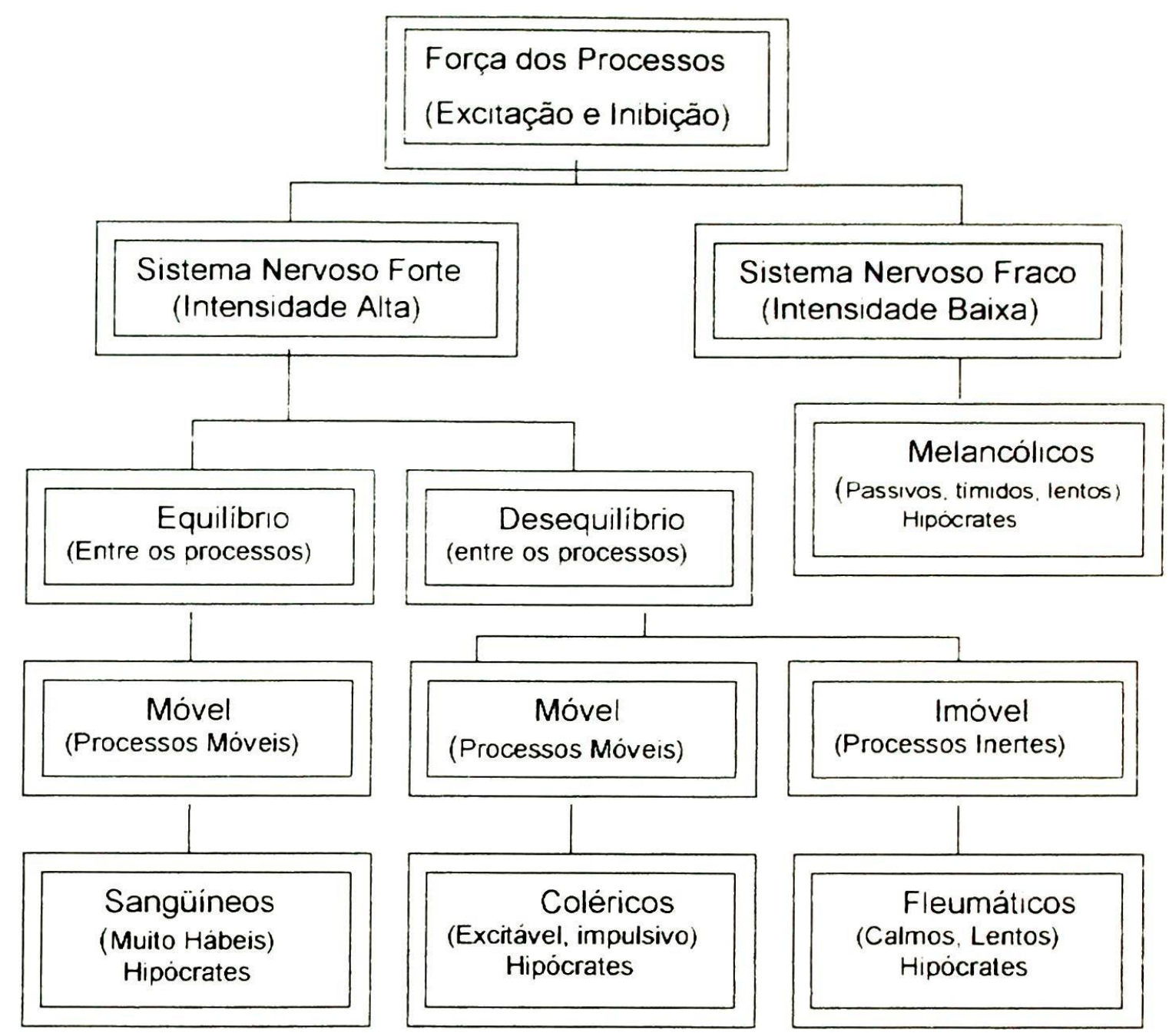

FIGURA 9 - Caracteristicas fundamentais do temperamento segundo PAVLOV (1979, p. 103).

Para KALININE (1994), as categorias gregas de Hipócrates podem ser diferenciadas da seguinte forma:

- sangüineo: os processos de excitação e inibição ocorrem no sistema nervoso de maneira forte. móvel e equilibrada, a sensibilidade tem nivel baixo;

- Colérico: os processo de excitação e inibição que ocorrem no sistema nervoso deste tipo são fortes. móveis e desequilibrados. Os processos da excitação prevalecem aos da inibição, a sensibilidade tem nivel baixo; 
- fleumático: os processos da excitação e inibição que ocorrem no sistema nervoso são fortes, porém inertes, tendo o nivel de sensibilidade baixo:

- melancólico: os processos de excitação e da inibição que ocorrem no sistema nervoso deste tipo são muito fracos e a sensibilidade tem nivel mais alto.

NEBYLITSIN (1996) descreve também as seguintes caracteristicas dos indivíduos que atendem às particularidades, anteriormente citadas

a) sangüineo:

- alegre e vivido

- energético e empreendedor;

- capaz de rapidamente assimilar o novo;

- facilmente suporta as derrotas e os desgostos

- facilmente se adapta às novas situações:

- assume novas tarefas apaixonadamente:

- fala alto, rápido e claro;

- conserva o autocontrole em situações inesperadas e complexas:

- tem boas a resistência e capacidade de trabalho. se este the interessa.

b) Colérico:

- impaciente;

- tem iniciativa:

- teimoso;

- inclinado ao perigo;

- tem fala rápida, apaixonada, mímica acentuada:

- desequilibrado, inclinado à irritação;

- às vezes é agressivo;

- capaz de agir rapidamente, e rapidamente tomar decisões.

c) fleumático:

- calmo e sangue frio; 
- consequiente nos empreendimentos:

- calado

- fala calmo. sem gestos:

- é constante em suas relações e interesses

- equilibrado nas relações com as pessoas

- se adapta às novas situações com dificuldades

\section{d) melancólico:}

- timıdo e retraido:

- perde-se facilmente em novas situações

- não acredita em suas forças:

- é inclinado a se fechar em si mesmo

- impressiona-se facilmente:

- è inclinado a suspeitas e dúvidas:

- sensivel e se fere facilmente

- zanga-se com facilidade e é pouco atıvo:

\subsection{Peculiaridades tipológicas do sistema nervoso do ser humano}

Considerando historicamente os estudos psicológicos que tentam entender o comportamento humano, torna-se evidente o indispensável conhecimento sobre as peculiaridades tipológicas dos individuos, seja na vida cotidiana. na vida profissional, ou ainda no esporte.

Atualmente, SAMULSKY, (1996, p.88) considera a Força dos Processos de Inibição dos Sistema Nervoso - "FPI", o Equilibrio da "FPE"/"FPI" dos Sistema Nervoso - "E" e a Mobilidade do Sistema Nervoso - "M", como as peculiaridades tipológicas determinantes do temperamento dos individuos. numa visão biológica do temperamento 
a) Força dos Processos de Excitação do sistema nervoso:

O fisiologista russo PAVLOV (1979) descobriu e estudou a Força do sistema nervoso e considerou uma das peculıaridades básıcas desse sistema. caracterizando o limite da capacidade de trabalho das células nervosas do córtex encefálico bem como a classificação dos tipos da atividade nervosa superior. ou seja, a capacidade de suportar um estimulos muito forte. ou com ação prolongada. sem entrar num estado de ınibição. Para TEMPLOV (1961) a força do sıstema nervoso se caracteriza também pela sensibilidade dos analisadores onde 0 sistema nervoso mais fraco é mais sensivel. por isso, ela possul a capacidade de reagir sobre os estimulos de intensidade mais baixo do que o sistema nervoso forte. Dessa forma, cada tipo de sistema nervoso tem seu lado positivo e negativo (do ponto de vista biológico ). não existindo os tipos bons e ruins, como se pensava antigamente. considerando-se que a força do sistema nervoso se caracteriza pela Força dos Processos de Excitação.

"A Força dos Processos de Excitação do sistema nervoso do ser humano è uma peculiaridade que influı em todas as outras, e é fator determınante no processo de desenvolvimento do comportamento" (KALININE, 1994, p.42)

As células que formam o sistema nervoso têm capacidade de conduzır a excitação da região onde ela surgiu para as outras regiões, e para as células nervosas próximas; por isso, a excitação torna-se o portador da informação sobre as propriedades das irritações externas e internas, sendo assim, juntamente com a inibição, os reguladores da atividade de todos os organismos e os sistemas do organismo. O processo de excitação surge somente com nivel determinado de estimulo externo, no qual prevalece o limiar absoluto de excitação sendo a peculiaridade de cada órgão do organismo.

As modalidades de difusão da excitação dependem da forma do sistema nervoso. Em sistemas nervosos mais primitivos, a atividade se conduz uniformemente em direções diversas, e se amortece gradualmente. Com a evolução dos seres vivos e conseqüente complexidade do sistema nervoso, aperfeiçoaram-se 
também as modalidades de transmissão da excıtação Taıs modalidades de transmissão permitem a difusão da excitação atè o final da via. sem qualquer debilitação

"O processo de excitação juntamente com o processo de inibição formam a base da atividade nervosa superior dos seres vivos visto que a força dos processos de excitação caracterıza a força do sistema nervoso " (PETROVISKY 1985 p 89)

\section{b) Força dos Processos de Inibição}

A Inibição è um processo ativo. Indissolúvel, lıgado com a excıtação. provocando retenção da atividade dos centros nervosos ou dos órgãos de trabalho No primeiro caso, è chamado de Inibição Central, no segundo caso. de Inibıção Periférica: foi descoberta em 1840. seus estudiosos desenvolveram a retenção das contrações do coração, através da imitação ritmica do nervo errático. "A origem da inibição por um bom tempo não era clara Inıcıalmente, os fisıológicos identificaram-na como um estado passivo das células nervosas, correspondentes ou não à sua exaustão" (PETROVISKY 1985, p 145)

Atualmente, revelam-se duas modalidades diferentes de inibições das atividades celulares: resultado da ativação das estruturas inibitórias peculiares: conseqüências da excitação prévia das células nervosas

A inibição é um componente necessário na atıvidade integral e de coordenação do sistema nervoso. RAMOS (1991) considera que os processos da inibição, juntamente com os processos da excitação, asseguram a adaptação do organismo ao meio ambiente, o qual muda constantemente.

\section{c) Mobilidade do sistema nervoso.}

PETROVISKY (1985), diz que a Mobilidade é uma das primárias propriedades do sistema nervoso, que consiste na capacidade de reagir rapidamente à mudanças do ambiente. Estudada por Pavlov, com a elaboração de metodologias básicas para seu diagnóstico, que baseavam-se na revelação da 
velocidade e facilidade de troca de uns processos nervosos para outros. da mesma ação, porém inversa. e na revelação da velocidade do surgimento e da extinção destes processos

\section{d) Equilibrio do sistema nervoso.}

São o equilibrio dos processos e excitação e inibição que ocorrem no sistema nervoso do ser humano. É uma peculiaridade que se revela pela proporção entre tais processos. A noção de Equilibrio dos processos nervosos foı ıntroduzıda também por Pavlov, que considerou como uma das peculiaridades do sistema nervoso independente. que formam juntamente com outras peculiaridades (força e mobilidade do sistema nervoso), o tipo de atividade nervosa superior (PETROVISKY. 1985, p.218)

No esporte é possivel observar tais diferenças direcionadas pelo desempenho dos atletas, ou seja, sangüineos desempenham melhor as tarefas quando ligadas às modalidades esportivas que exijam coragem, e ligados com um alto nivel de atividade e mobilidade; Coléricos, preferem modalidades esportivas com alto nivel de emoção; Fleumáticos preferem modalidades esportivas constituidas de movimentos calmos, uniformes e com tendência para 0 desenvolvimento metódico das capacidades físicas e treinamento de movimentos esportivos de modo prolongado; Melancólicos preferem modalidades esportivas individuais, que não são ligadas ao combate imediato, como em equipes (VIATIKIN, 1978, p.120).

Estudos realizados por SAMULSKI (1996), utilizando-se do "EPI" Eysenk Personality Inventory, comprovaram diferenças de personalidade em determinadas modalidades, ou seja, corredores de maratona, atiradores e ciclistas no grupo dos melancólicos; nadadores e lutadores de alto nivel, no grupo dos coléricos; atletas de olimpiadas, no grupo dos sangüineos.

Considerando o revisão literária acima descrita, pode-se atribuir à teoria de temperamento de PAVLOV (1979) a mais aplicável no esporte, pois conhecendo a Força dos Processos de Excitação do ser humano ainda na infância, pode-se prever com alto nivel de probabilidade o comportamento na idade adulta. 
A realização de um estudo desta natureza justifica-se na possibilidade de contribuirmos para que a atleta seja analisada e interpretada, e cada vez mais, pela ótica da psicologia desportiva. Pois, se for possivel identificar e controlar variáveis que atuam de forma prejudicial nas respostas psıcológıcas da atleta de voleibol: pode-se maximizar seu desempenho em situações de treinamento e em competições desportivas, onde se caracterıza os seguıntes aspectos

- A grande preocupação que envolve profissionais atuantes no meio voleibolístico, quanto em nivel de ansiedade que os atletas apresentam durante o treinamento e o jogo:

- O comparativo entre atacantes de força (ponteiras) e de velocidade (centraıs). tanto para A-Estado quanto para A-Traço, com o objetivo de aumentar a preocupação quanto à análise psicológica:

- O cruzamento de dados voltados à ansiedade no voleibol com as peculiaridades tipológicas do sistema nervoso central;

- Poucos estudos sobre o rendimento das atletas durante os treinamentos, e os jogos, com a influência da ansiedade em posições epecificas no voleibol feminino de alto rendimento;

- Proporcionar aos técnicos um estudo com aspectos da psicologia desportiva. visando um maior desenvolvimento tático.

\section{HIPÓTESES ESTATISTICAS}

- Hipótese 1 (H1)

Ho: Não há diferenças significativas $(p<0,05)$ entre o nivel de Ansiedade - Traço e - nivel da Força dos Processos de Excitação do sistema nervoso de atletas de voleibol do sexo feminino. 
Ha Há diferenças significativas $(p<0.05)$ entre o nivel de Ansiedade - Traço e o nivel da Força dos Processos de Excitação do sistema nervoso de atletas de voleibol do sexo feminino.

\section{- Hipótese $2(\mathrm{H} 2)$}

Ho: Não há diferenças significativas $(p<0.05)$ entre as peculiaridades tıpológicas do sistema nervoso central das atletas de voleibol do sexo femınıno

Ha $\mathrm{Há}$ diferenças significativas $(p<0,05)$ entre as peculiarıdades tipológıcas do sistema nervoso central das atletas de voleibol do sexo femınıno

\section{- Hipótese $3(\mathrm{H} 3)$}

Ho: Não há diferenças sıgnificatıvas $(p<0,05)$ de A-Traço entre as duas posıções de ataque (ponta e meio) em atletas de voleibol do sexo feminino.

Ha: Há diferenças significativas $(p<0.05)$ de A-Traço entre as duas posiçōes de ataque (ponta e meio) em atletas de voleibol do sexo feminino.

\section{- Hipótese $4(\mathrm{H} 4)$}

Ho: Não há diferenças sıgnificativas $(p<0,05)$ de A-Traço entre as duas posições de ataque (ponta e meio) e as peculiaridades tipológicas do sistema nervoso em atletas de voleibol do sexo feminino 
Ha : Há diferenças significativas $(p<0.05)$ de A-Traço entre as duas posıções de ataque (ponta e meio) e as peculiaridades tıpológicas do sıstema nervoso em atletas de voleibol do sexo femınıno

\section{- Hipótese 5 (H5)}

Ho: Não há diferenças sıgnificatıvas $(p<0.05)$ entre a força dos processos de excitação e as peculiaridades tıpológicas do sıstema nervoso em atletas de voleıbo do sexo feminino.

Ha: Há diferenças significativas $(p<0.05)$ entre a força dos processos de excitação e as peculiaridades tipológicas do sistema nervoso em atletas de voleibol do sexo feminino

\section{DELIMITAÇÃO DO ESTUDO}

O estudo restringiu-se a pesquisar opiniões de 80 atletas de voleıbol do sexo feminino. com idade cronológica entre 18 e 30 anos, de alto nivel técnico integrantes de equipes representativas de clubes/empresas do Brasil durante a SuperLiga 2001, através dos questionários denomınados 'IDATE' e "STRELAU".

Não serão considerados no estudo, os aspectos relacionados com a estrutura organizacional e funcional dos clubes empresas e associaçōes que não são sujeitos desta pesquisa.

\section{METODOLOGIA}

O presente estudo apresentou uma pesquisa aplicada descritiva, com o objetivo de verificar e comparar os niveis de ansiedade competitiva "A-Traço" em 
atletas de voleıbol do sexo femınıno quanto às suas posıções especificas de ataque (ponterras e centrais). diferenciadas pela força do processo de excitação de seu sistema nervoso durante as finais da SuperLıga na temporada 2001. divisão especial

\subsection{Sujeitos da pesquisa e amostragem}

A população constitui-se de 80 atletas de voleibol categorıa adulto. do sexo feminino, onde 40 jogadoras pertecem à posição de meı de rede e outras 40 à posição de ponta de rede com idade cronológica entre 18 e 30 anos. provenientes das dez equipes melhores colocadas na Superliga. temporada 2001

\subsection{Instrumentos de medida}

Para o diagnóstico do nivel de A-Traço dos individuos da amostra. utilizou-se o "Inventário de Ansiedade-Traço - IDATE". cujo indice de validação é de $r=0,62$ - (ANEXO I). Este é composto de uma escala de auto - relato com 20 afirmações, as quais requerem a descrição de como os sujeitos se sentem $O$ questionário possui uma escala de 4 pontos, sendo: 1 Quase nunca; 2 Às vezes: 3. Freqüente; 4 Quase sempre (SPIELBERGER et al., 1979).

Para diagnosticar as Peculiaridades Tipológicas do sistema nervoso (Força dos Processos de Excitação, Inibição e Mobilidade do sistema nervoso). utilizou-se a seguinte metodologia:

- "Questionário de Strelau", (ANEXO II), o qual apresentou um grau de fidedignidade $r=0,84$, objetividade $r=0,65$ e validade $r=0,54$. Este instrumento permite ao pesquisador conhecer os seres humanos com temperamentos sangüineos, coléricos, fleumáticos e melancólicos com $p<0.05$ (VIATIKIN, 1989, $p$ 116). Sendo de natureza russa, foi realizado uma validação de conteúdo pelo Prof. Silveira, mostrando nesta validação, um coeficiente de correlação entre os 
resultados obtidos de $r=0.94$ com $p<0.001$ (KALININE. 1994) o que o torna fidedigno

\subsection{Procedimentos}

Na primeira fase da pesquisa foı realizada a investigação do nivel de ATraço das atletas de ambas as posições (meı e ponta) das 10 equipes melhores classificadas nas finaıs da Superliga - 2001, em seus respectivos clubes $\mathrm{Na}$ segunda fase foi realizada investıgação das Peculıaridades Tipológicas do sıstema nervoso da mesma população, porém, em dias diferentes da primeira fase. respeitando local e horários determinados

A coleta de dados realizou-se durante os meses de Março e Abril de 2001. Durante este periodo, as atletas sofreram questionamentos do pesauisador por duas vezes. Tais intervenções realizaram-se no periodo matutino, antecedendo o treinamento com a permissão do supervisor responsável

$\mathrm{Na}$ terceira fase, através dos métodos da estatistica paramétrica (média. desvio padrão e teste t-Student, para amostra independente). realizou-se a análıse dos resultados adquiridos nas fases anteriores, para verificar a diferença entre os niveis de A-Traço dos sujeitos da amostra com nivel alto médio e baixo da força dos Processos de Excitação de seu sistema nervoso bem como as demaıs Peculiaridades Tipológicas do sistema nervoso de tais individuos.

$\mathrm{Na}$ quarta fase, através da análise e discussão dos resultados adquiridos, as conclusões foram elaboradas para este estudo.

\section{RESULTADOS E DISCUSSÕES}

Utilizamos, para a análise dos dados, o programa estatístico "SPSS 8.0 for Windows", que é um software para computadores do tipo IBM PC ou compativeis. Este programa é um pacote estatistico, integrado com inúmeras 
opções de funções, acompanhadas de gráficos É proposto para uso em pesquisas ligadas a todas as áreas cientificas.

\subsection{Niveis de A-Traço dos sujeitos da amostra}

Nesta primeira fase da pesquisa, realızou-se a identificação dos niveıs de A-Traço dos sujeitos que compõem a amostra Os resultados, apresentam-se no ANEXO III E TABELA 1

TABELA 1 - Comparativo estatístico dos niveis de a-traço dos sujeitos da $\underline{\text { amostra }}$

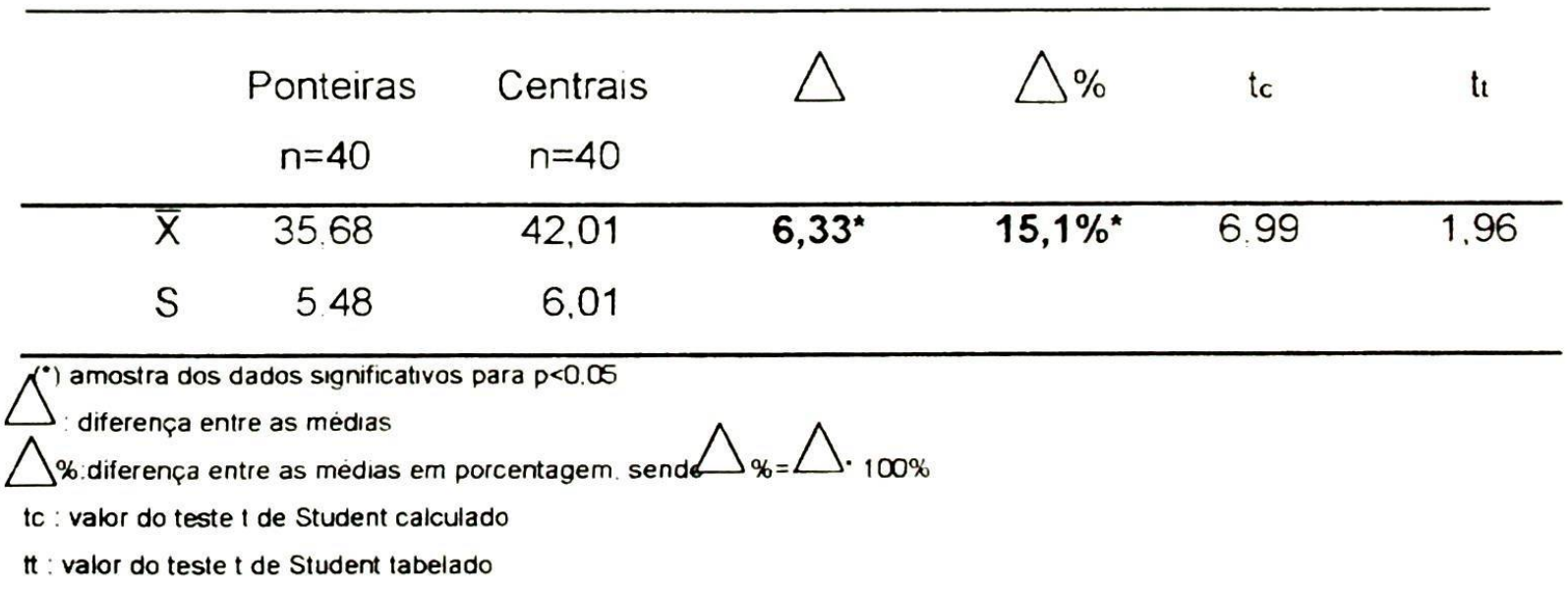

Os resultados apresentados na TABELA 1, mostram que as atletas que jogam no meio da rede (centrais), possuem nivel de A-Traço mais elevado $(p<0,05)$ que as atletas que jogam na ponta da rede (ponteiras), com diferença de $15,1 \%$.

Os resultados dos niveis de A-Traço analisados nesta parte da pesquisa vão ao encontro de alguns estudos já realizados, os quais investigaram as diferenças comportamentais entre atletas de velocidade e de força no esporte. LAWTHER (1973) afirma que alguns fatores como sexo, idade, antecedentes de experiências, nivel de habilidade, nivel de qualidade física e tipo de personalidade. afetam a qualidade ou grau de emoção, que terá um estimulo sobre o 
desempenho ou aprendizagem do individuo Para HACKFORT \& SCHENKMEZGER (1993) a ansıedade è um dos prıncıpaıs componentes emocionais

CRATTY (1984) cita alguns estudos realizados em relação a ansıedade manifestada por mulheres, que estavam diretamente ligados à questão cultural da mulher no esporte. ou seja. à visão que as próprias mulheres tinham de si mesmas. e o medo do julgamento (preconceito) da comunidade e colegas atletas sobre seu desempenho e postura de mulher atleta. Deve-se considerar que tal estudo for realizado em 1977 quando a presença femınina no esporte era novidade nos Estados Unidos da América

Outro estudo citado por CRATTY (1987), fol realızado o qual concluiu que mulheres, atletas, velozes. podem abrigar diversos medos ao competırem no esporte. Essas mulheres tiveram escores mais altos quando se tratava do "medo do sucesso", enquanto que nas atletas de força, prevaleceu o "medo do fracasso". sendo tais "medos", causadores de ansiedade.

CATTELL (1975) cita que a ansiedade está correlacionada ao traço básico de personalidade designado " $A$ ", que signifıca "afectotimia - vs - sızotımıa" (emoção). Este traço tem uma determinação hereditárı muito aprecıável sendo ele significativamente mais alto nas mulheres atletas de velocidade com relação às atletas de força, o que explicaria - segundo o autor - " a maior expressıvidade emotiva e maior meiguice dessas mulheres“, relacionando-se com o fato de ser maior, nas centrais, a taxa de ocorrência de insanidades maniaco-depressivas e. nas ponteiras, de esquizofrenia.

Para o diagnóstico dos niveis de A-Traço dos individuos das amostras (nivel alto; nivel médio e nivel baixo), foram calculadas as seguintes medidas. somente das atletas de mesma posição:

$$
\begin{aligned}
& \mathrm{X} \text { - média } \\
& \mathrm{S}-\text { desvio padrão } \\
& \overline{\mathrm{X}}_{1}=\overline{\mathrm{X}}=\left(0,675^{\star} \mathrm{S}\right) \\
& \overline{\mathrm{X}}_{2}=\overline{\mathrm{X}}-\left(0,675^{\star} \mathrm{S}\right) \\
& \overline{\mathrm{X}}_{3}=\overline{\mathrm{X}}+\left(0,675^{\star} \mathrm{S}\right)
\end{aligned}
$$


De acordo com as recomendações de CRATTY (1984), as atletas que apresentam o nivel de A-Traço (NA)

$$
\begin{array}{ll}
\mathrm{NAa}>x+\left(0.675^{\star} \mathrm{S}\right) & \rightarrow \text { nivel alto de A-Traço } \\
\mathrm{Nam}=-\left(0.675^{\star} \mathrm{S}\right) & \rightarrow>\text { nivel médio de A-Traço } \\
\mathrm{NAb}<*-\left(0.675^{\star} \mathrm{S}\right) & \rightarrow>\text { nivel baixo de A-Traço }
\end{array}
$$

Considerando-se os resultados da determınação do nivel de A-Traço dos sujeitos da amostra. estabeleceu-se o diagnóstıco final Os valores para os niveis de A-Traço das atletas centrais e ponteiras do voleibol feminino adulto. integrantes das dez melhores colocadas na SuperLıga 2001 são:

- Para as atletas de força (ponteiras ou entrada de rede)

$$
\begin{aligned}
& \text { NAa }>35.68+(0,675 * 5.48)=39.4 \\
& N A m=35.68 \pm\left(0.675^{*} 5.48\right)=39.4 \text { a } 32 \\
& N A b<35.68-(0,675 * 5.48)=32
\end{aligned}
$$

- Para as atletas de velocidade (centrais ou meio de rede)

$$
\begin{aligned}
& \text { NAa }>42,01+\left(0,675^{\star} 6,01\right)=46,1 \\
& N A m=42,01 \pm\left(0,675^{\star} 6,01\right)=37,9 a 46.1 \\
& N A b<42,01-\left(0,675^{\star} 6,01\right)=37,9
\end{aligned}
$$

\subsection{Peculiaridades tipológicas do sistema nervoso dos sujeitos da amostra}

Nesta fase da pesquisa, foram analisadas as Peculiaridades Tipológicas do sistema nervoso dos individuos da amostra, sendo elas: 
- Força dos Processos de Excitação do sistema nervoso - FPE.

- Força dos Processos de Inibição do sıstema nervoso - FPI:

- Mobilidade do sistema nervoso - M:

- Equilibrıo entre os Processos de Excitação e Inıbição -E

Os resultados adquiridos nesta fase da pesquisa. estão apresentados no ANEXO III E TABELA 2.

TABELA 2 - Comparativo estatistico das peculıarıdades tipológıcas do sistema nervoso dos sujeltos da amostra

\begin{tabular}{|c|c|c|c|c|}
\hline & FPE & FPI & $M$ & $E$ \\
\hline & \multicolumn{3}{|c|}{$\begin{array}{l}\text { CENTRAIS } \\
\qquad N=40\end{array}$} & \\
\hline $\bar{x}$ & 6301 & 62.55 & 61.19 & 103 \\
\hline \multirow[t]{2}{*}{$S$} & 8.16 & 9.63 & 7.29 & 0.16 \\
\hline & \multicolumn{3}{|c|}{$\begin{array}{c}\text { PONTEIRAS } \\
\mathrm{N}=40\end{array}$} & \\
\hline $\bar{x}$ & 55.9 & 57,22 & 60.62 & 1.01 \\
\hline$S$ & 9.85 & 947 & 8.14 & 0,21 \\
\hline$\Delta$ & $7,11^{\star \star}$ & $5,33^{\star}$ & 0.57 & 0.02 \\
\hline$\Delta \%$ & $11,3 \%$ ** & $8,5 \% *$ & 0.93 & 1.94 \\
\hline$t_{c}$ & 4.93 & 2.23 & & \\
\hline
\end{tabular}

os resultados com (") são verdadeıros com $p<0.05$ os resultados com ("*) são verdadeiros com $p<0.001$

1 : diferença entre as médias

$\wedge \%$ : diferença entre as médias em porcentagem, onde $\wedge \%=\wedge-100 \% / x$

tc : valor do teste $t$ de Student calculado

Atravès dos resultados apresentados na TABELA 2, nota-se que. em média, as atletas de velocidade desta amostra, possuem a Força dos Processos de Excitação "FPE" de seu sistema nervoso mais alto, com $p<0,001$, comparando-se à 
Força dos Processos de Excitação dos sistema nervoso dos sujeitos de ponta de rede, com diferença de $7.11 \%$

A Força dos Processos de Inibição "FPl", também se apresentou em média maıs elevada com $p<0.05$. nas centraıs, apresentado diferença de 5.33\% em relação às ponteiras

Quanto à Mobilidade entre os processos do sistema nervoso " $M$ ". os sujeitos de velocidade apresentaram nivel $0.93 \%$ mais elevado com relação aos sujeitos de força. Porém essa diferença não è verdadeıra com $p<0.05$

$O$ equilíbrio entre os processos da Excıtação e Inıbição do sistema nervoso " $E$ ", apresentou-se com nivel mais elevado de $1.94 \%$ nas atletas centrais com relação às atletas de ponta Porém esta diferença não è verdadeıra com 0 $<0,05$.

Estes resultados assemelham-se a estudos realizados por KALININE (1994), os quais investigaram as Peculiaridades Tipológicas do sistema nervoso de atletas com as mesmas qualidades fisicas, porém de outro esporte Verificou-se que há diferença da Força dos Processos de Excitação do sıstema nervoso de atletas de velocidade e atletas de força, sendo a de velocidade, $12.7 \%$ maır em relação a de força.

Para que seja possivel diagnosticar os niveis de cada Peculiarıdade Tipológicas dos sujeitos da amostra, ou seja, nivel alto, nivel médio e nivel baixo. realizou-se o mesmo procedimento, utilizando-se para os niveis de A-Traço, já apresentados na primeira fase desta pesquisa. Dessa forma. têm-se:

\section{- Para a Foça dos Processos de Excitação do sistema nervoso (FPE)}

- atletas atacantes de velocidade (centrais)

$$
\begin{aligned}
& \text { FPEa }>63,01+(0,675 * 8,16)=68,5 \\
& \text { FPEm }=63,01=(0,675 * 8,16)=68,5 \text { a } 57,5 \\
& \text { FPEb }<63,01-(0,675 * 8,16)=57,5
\end{aligned}
$$


- atletas atacantes de força (ponteiras)

$$
\begin{aligned}
& \text { FPEa }>55.9+(0.675 * 9.85)=62.5 \\
& \text { FPEm }=55.9 \pm(0.675 * 9.85)=49.2 \text { a } 62.5 \\
& \text { FPEb }<55.9-(0.675 * 9.85)=49.2
\end{aligned}
$$

- Para a Força dos Processos de Inibição do sistema nervoso (FPI)

- atletas atacantes de velocidade (centrais)

$$
\begin{aligned}
& \mathrm{FPla}>62.55+(0.675 * 9.63)=69.0 \\
& \mathrm{FPIm}=62.55 \pm(0.675 * 9.63)=56.0 \text { a } 69.0 \\
& \mathrm{FPIb}<62.55-(0.675 * 9.63)=56.0
\end{aligned}
$$

- atletas atacantes de força (ponteiras)

$$
\begin{aligned}
& \text { FPla }>57.22+(0.675 * 9.47)=63.6 \\
& \text { FPIm }=57.22 \pm(0.675 * 9.47)=50.8 \text { a } 63.6 \\
& \text { FPIb }<57.22-(0.675 * 9.47)=50.8
\end{aligned}
$$

- Para a Mobilidade do sistema nervoso (M)

- atletas atacantes de velocidade (centrais)

$$
\begin{aligned}
& M a>61.19+(0,675 * 7,29)=66.1 \\
& M m=61.19 \pm(0.675 * 7.29)=56.3 \text { a } 66.1 \\
& M b<61.19-(0,675 * 7.29)=56.3
\end{aligned}
$$

- atletas atacantes de força (ponteiras)

$$
\begin{aligned}
& M a>60,62+(0,675 * 8,14)=66,1 \\
& M m=60,62 \pm(0,675 * 8,14)=57 \text { a } 66.1 \\
& M b<60,62-(0,675 * 8,14)=57
\end{aligned}
$$


- Para o Equilibrio entre os processos da Excitação e da Inibição do sistema nervoso (E)

Segundo KALININE (1994), independentemente do sexo. os sujeitos que possuem:

$E=1.0 \pm 0.1 \rightarrow$ apresentam equilibrio entre os processos de Excitação e o processo de Inibição do sistema nervoso.

E > 1,1 -> possuem prevalência do processo da Excitação sobre o processo da Inibição;

$E<0.9$-> possuem prevalência do processo da Inibição sobre o processo da Excitação.

8.3 Resultados de diferenças entre niveis de a-traço e peculiariadades tipológicas do sistema nervoso dos individuos

A partir da consideração feita por VIATIKIN (1978). PETROVISKY (1985). e KALININE (1994), na qual salienta que a Força dos Processos de Excitação (FPE) é considerada uma peculiaridade básica do sistema nervoso e. Influente nas demais forças descritas neste estudo, decidiu-se investigar a existência de relação entre a FPE e A-Traço. Para isto, foram formados seis grupos com as atletas que possuem tipo de sistemas nervosos semelhantes, ou seja, através da Força dos Processos de Excitação do sistema nervoso, formaram-se três grupos de atletas atacantes de meio (centrais), com niveis da Força dos Processos de Excitação alto. médio e baixo. Com mesmo procedimento, formaram-se também, três grupos de atletas atacantes de ponta (ponteiras)

Para a formação dos seis grupos, de acordo com o nivel de Força dos Processos de Excitação do sistema nervoso, as atletas foram separadas por posição e agrupadas pelo nivel de "FPE", em ordem decrescente. Posteriormente. formaram-se os grupos, sendo que o primeiro grupo compôs-se por sujeitos, com o nivel mais alto da média, e o terceiro grupo por sujeitos, com nivel de "FPE" mais baixo (veja ANEXO IV). 
Os resultados finais da análise dos dados adquiridos nesta pesquisa. estão apresentados nas TABELAS 3.4.5. 6 e 7

Os resultados apresentados na TABELA 3 mostram que todas as peculiaridades tipológıcas do sistema nervoso investigadas são dependentes da Força dos Processos de Excitação das atletas atacantes de meio. A Força dos Processos de Inibição (FPI). o Equilibrio entre os processos da Excitação e da Inibição (E) e a Mobilidade dos processos nervosos (M). aumentam seus indices. na medida em que aumenta o nivel da Força dos Processos de Excitação (FPE) O nivel de A-Traço diminui a medıda em que cresce o nivel da FPE

TABELA 3 - Comparativo estatístico entre "a-traço" e as peculiaridades tıpológicas do sistema nervoso das atletas centrais com nivel alto, médıo e baixo da força dos processos da excitação.

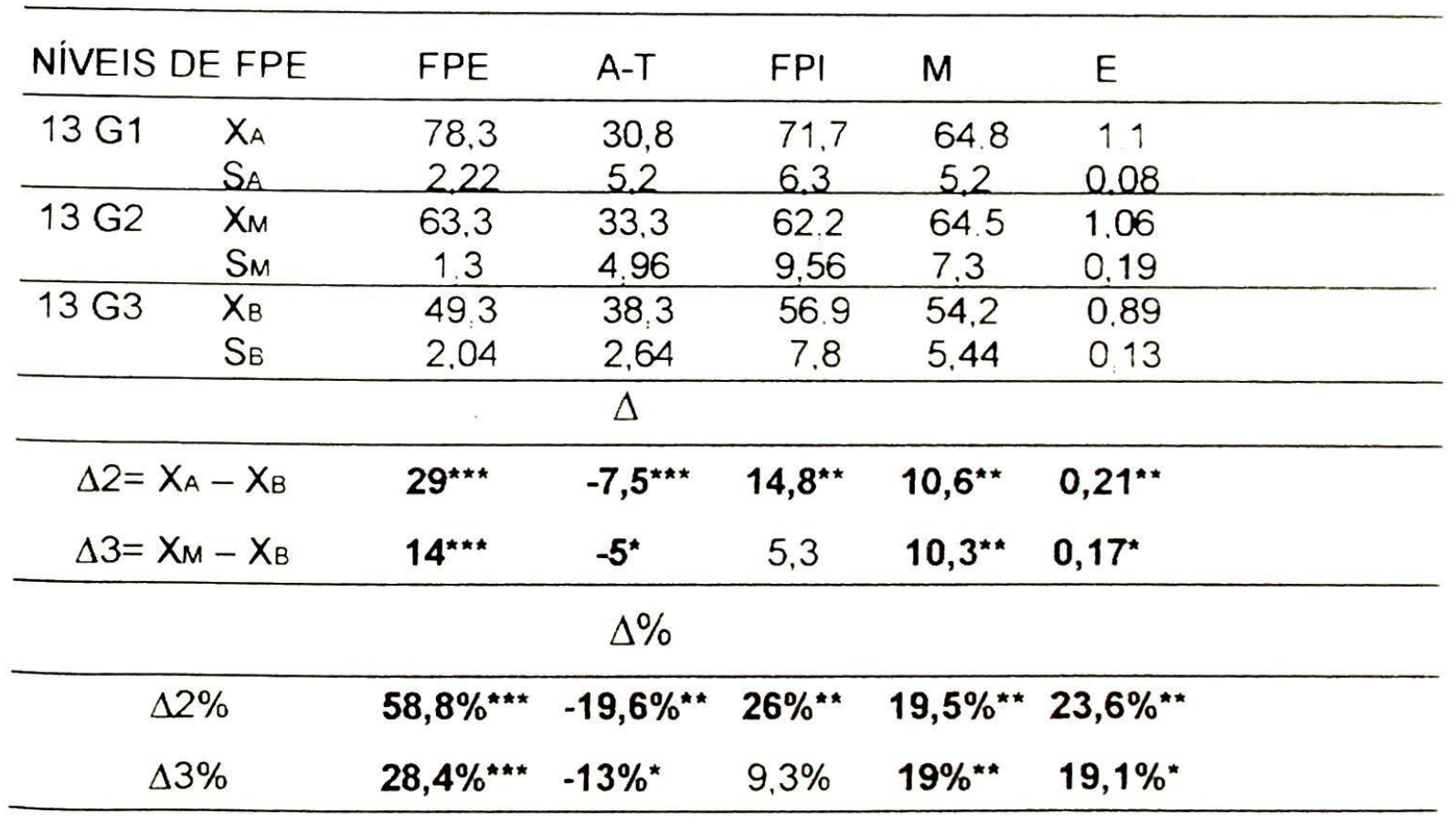

os resultados marcados com ( $\left(^{\circ}\right)$ são verdadeiros com $p<0.05$

os resultados marcados com ( $" *$ ) são verdadeiros com $p<0,001$

os resultados marcados com ( $\cdots$ ) são verdadeiros com $p<0,0001$

G1 - grupo com nivel alto da FPE

G2 - grupo com nivel médio da FPE

G3 - grupo com nivel baixo da FPE

$\Lambda$ : diferenças entre as médias

$\Lambda \%$ diferenças entre as médias em porcentagem, onde $\Lambda \%=\Lambda-100 \% / \mathrm{Xb}$

FPE: Força dos Processos de Excitaçáo do sistema nervoso do ser humano 
FPI: Força dos Processos de Inibição do sıstema nervoso do ser humano

M: Mobilidade do sistema nervoso

E: Equilibrio entre os processos de Excitação e da Inibição

A-T: Ansiedade-Traço

$X:$ média

S: desvio padrão

tc: valor do teste t de Student calculado

Os resultados apresentados na TABELA 4. mostram que a Força dos Processos de Inibição (FPI) das atletas com nivel da Força dos Processos de Excitação (FPE) alto é maior, com $p<0,001$, do que as atletas com nivel de "FPE" baixo. Essa diferença consiste em 26\%. A força dos Processos de Inibição. das atletas com nivel médio da Força dos Processos de Excıtação, é maior 9.3\% do que nas atletas com baixo nivel da "FPE": Porém, tal diferença não tem confiança para $p<0,05$.

A Mobilidade dos processos nervosos $(M)$ das atacantes com nivel da Força dos Processos de Excitação alto é maior, $\operatorname{com} p<0.001$. do que as atacantes com nivel da Força dos Processos de Excitação baixo. Essa diferença consıste em $19,5 \%$ entre atacantes com nivel baixo e atletas com nivel alto da "FPE" As atletas com nivel médio da "FPE" de seu sistema nervoso possuem maior nivel de Mobilidade com $p<0,001$, que as atletas com nivel baixo da "FPE" apresentando diferença de $19 \%$.

As atletas com nivel alto da Força dos Processos de Excitação possuem indice de Equilibrio entre os processos da Excitação e da Inibição $(E)$. com $p$ < 0,001 , com prevalência dos Processos de Excitação sobre os Processos da Inibição $(E=1,1)$. As mesmas com nivel baixo da "FPE", possuem, com $p<0.05$. indice de Equilibrio com prevalência dos Processos da Inibição sobre os da Excitação $(E<0,9)$.

O nível de A-Traço das atletas com nivel da Força dos Processos de Excitação alta, é menor, com $p<0,05$, do que nas atletas com Força dos Processos de Excitação de nivel baixo. Essa diferença consiste em 19,6\%. Essas. com nivel médio da "FPE" possuem nivel de A-Traço menor, com $p<0,05 \%$, que as com nivel baixo da "FPE". Essa diferença consiste em 13\%. 
Os resultados apresentados na TABELA 4, mostram que também nas atacantes de ponta. todas as Peculıaridades Tıpológicas ınvestıgadas são dependentes do nivel da Força dos Processos de Excitação do sistema nervoso. pois a Força dos Processos da Inibição, o Equilibrio e a Mobilidade aumentam seus indices na medida em que aumenta o nivel da Força dos Processos de Excıtação (FPE). O nivel de A-Traço dimınui à medida em que aumenta o nivel de "FPE"

O nivel de "A-Traço" das atletas com nivel da Força dos Processos de Excitação alta é menor, com $p<0,001$. do que nas atletas com força dos Processos de Excıtação de nivel baixo. Essa diferença consiste em $22.6 \%$ entre as atletas com nivel médıo e as com nivel alto da "FPE". Essas atacantes. com nivel médio da "FPE" possuem nivel de A-Traço $7.1 \%$ menor que as atacantes com nivel baixo. porém essa diferença não tem confiança com $p<0.05$

TABELA 4 - Comparativo estatístico entre "a-traço" e as peculiaridades tipológıcas do sistema nervoso das atletas de meı. com nivel alto médıo e baixo da força dos processos da excitação

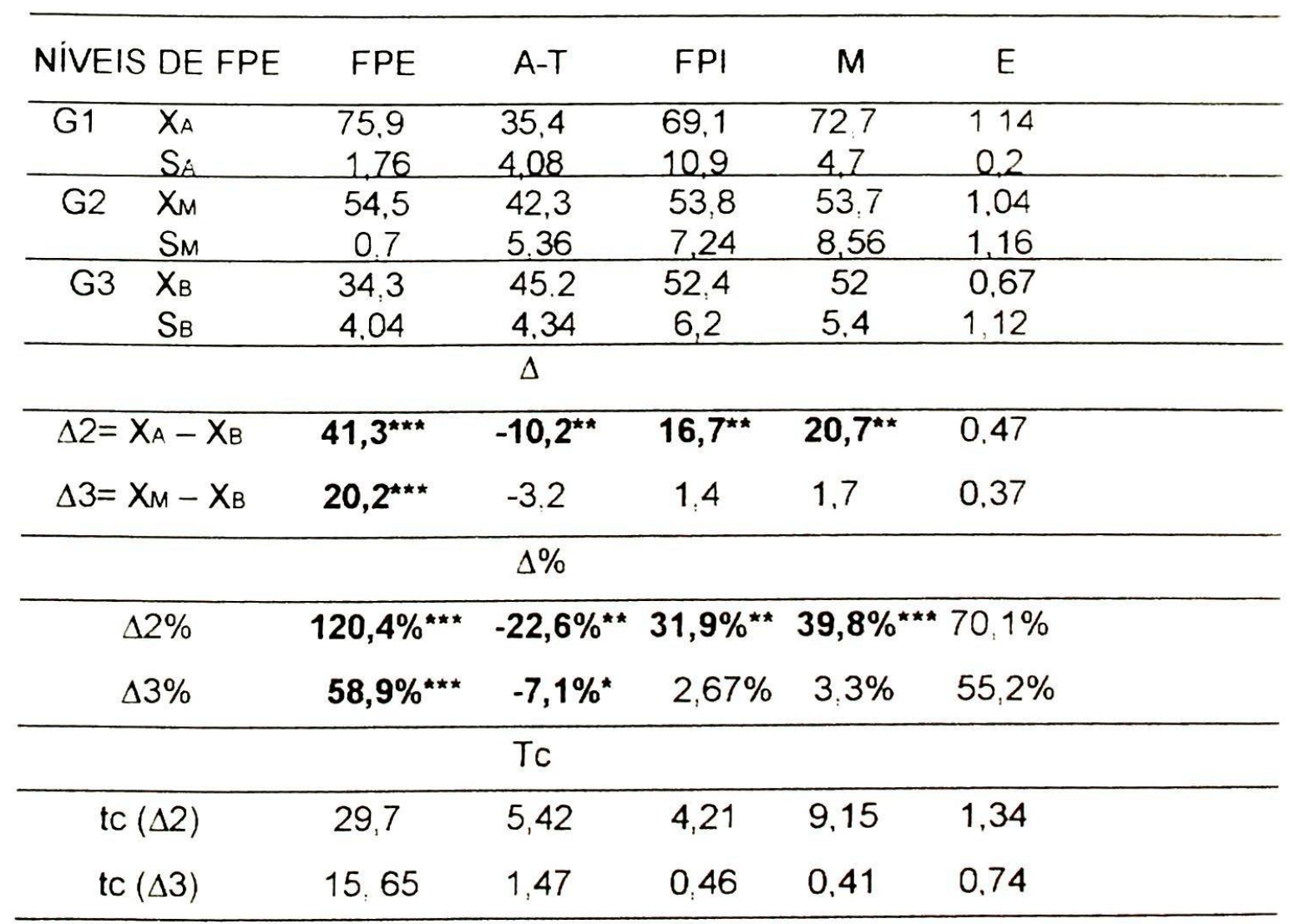




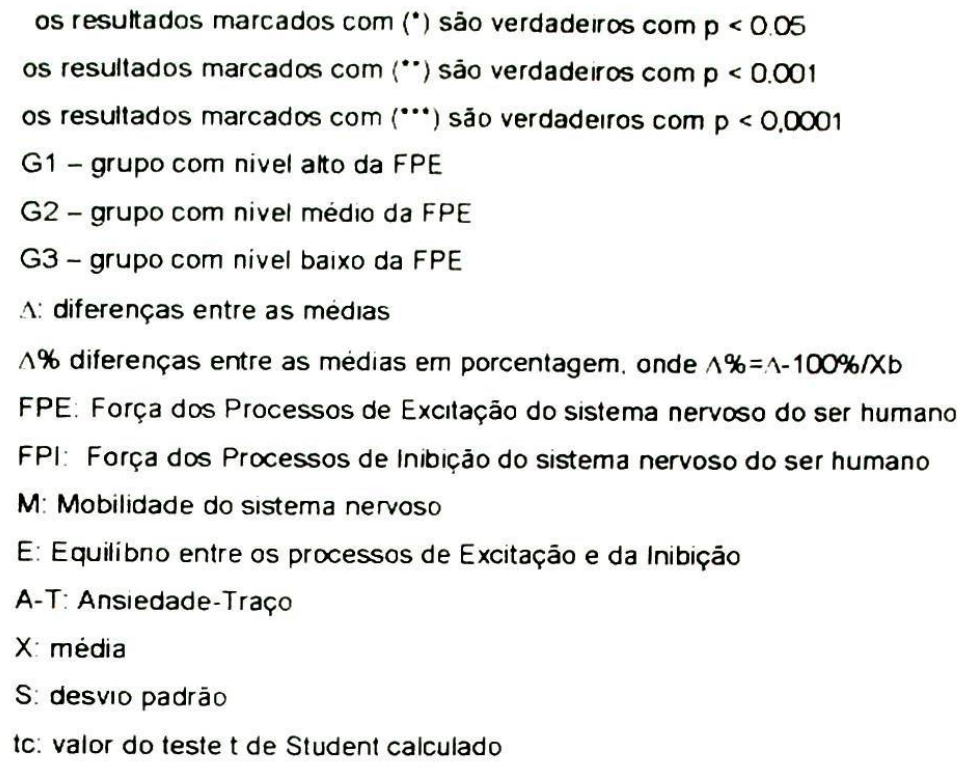

A Força dos Processos de Inibição (FPI) das atacantes com Força dos Processos de Excitação (FPE) alto é maior, com $p<0.001$, que as com nivel baıxo da "FPE", tendo uma diferença de $31,9 \%$ entre as com nivel alto e as com nivel baixo de "FPE". As atletas com nivel médio da "FPE", possuem nivel da Força dos Processos da Inibição $2,67 \%$ maior que as atletas com nivel baıxo da "FPE", porem esse resultado não tem confiança com $p<0,05$

A Mobilidade dos processos nervosos (M) das atletas com nivel da Força dos Processos de Excitação alto é maior, com $p<0,0001$. que nas atletas com nivel da Força dos Processos de Excitação baixo. Essa diferença consiste em $39,8 \%$ entre atletas com nivel baixo e atletas com nivel alto da "FPE". Essas com nivel médio da "FPE" de seu sistema nervoso possuem nivel de Mobilidade 3.3\% maior que as com nivel baixo da "FPE", porém, esta diferença não tem confiança com $p<0,05$

As atacantes com nivel alto da Força dos Processos de Excitação possuem indice de Equilibrio entre os processos da Excitação e da Inibição $(E)$ como predomínio, e 70,1\% dos Processos de Excitação sobre os Processos da Inibição $(E>1,1)$, porém, esta diferença não tem confiança com $p<0,005$. As atletas com nivel baixo da "FPE", possuem indice de Equilibrio com 55,2\% de 
predominio dos Processos da Inibição sobre os da Excitação $(E<0.9)$. esta diferença. tambèm não tem confiança para $p<0.05$.

De um modo geral, os resultados apresentados nas TABELAs 5 e 6 mostram que Peculiaridades Tipológicas básıcas do sistema nervoso. taıs como "FPI". "M" e "E" são diretamente proporcıonaıs à Força dos Processos de Excitação do sistema nervoso, e a "A-Traço" é inversamente proporcıonal à Força dos processo de Excitação do sistema nervoso

Tais resultados comprovam que a Força dos Processos da Excıtação é uma peculiarıdade principal do sistema nervoso. pois realmente ınfluı na A-Traço e nas demaıs Peculiaridades Tipológıcas investigadas nesta pesquisa. comprovandose dessa forma. a hipótese elaborada neste estudo

\subsubsection{Resultados sobre "a-traço" e outras peculiaridades tipológicas}

Com a intenção de investigar a relação entre as demais peculiaridades básicas do sıstema nervoso "FPl", "M" e "E" e a A-Traço, utilizaram-se os procedimentos da análise anterior ou seja. com os individuos da amostra formularam-se seis grupos (três de centrais e três de ponteıras). dıvididos pelo nivel da Força dos Processos da Inibição (ANEXO V). Mobilidade (ANEXO VI) e Equilibrio (ANEXO VII) entre os processos da Excitação e da Inibição (E). Os resultados adquiridos nesta fase da pesquisa, estão apresentados nas TABELAS 5. 6 e 7 .

Os resultados da TABELA 5, mostram que os niveis de A-Traço dos individuos da amostra, diminuem na medida em que aumenta seus niveis da Força dos processos de Inibição. 
TABELA 5 - Comparativo estatistıco entre "a-traço" e as peculiaridades tipológicas dos sujeitos com nivel alto médio e baixo de (FPI).

\begin{tabular}{|c|c|c|c|c|c|}
\hline & & \multicolumn{2}{|c|}{ CENTRAIS } & \multicolumn{2}{|c|}{ PONTEIRAS } \\
\hline \multicolumn{2}{|c|}{ NIVEIS DE FPI } & FPI & $A-T$ & FPI & $A-T$ \\
\hline \multirow[t]{2}{*}{ G1 } & $X_{A}$ & 79.9 & 30,9 & 78 & 37 \\
\hline & $S_{A}$ & 2.72 & 5.68 & 4.56 & 6,2 \\
\hline \multirow{2}{*}{ G2 } & $X_{M}$ & 62.4 & 36,6 & 57 & 39.4 \\
\hline & $S_{M}$ & 076 & 5.2 & 0.92 & 5.32 \\
\hline \multirow[t]{3}{*}{ G3 } & $X_{6}$ & 444 & 408 & 37 & $41,7^{\star}$ \\
\hline & $\mathrm{Se}$ & 2.2 & 5,8 & 4,32 & 6,9 \\
\hline & & & $\Delta$ & & \\
\hline \multicolumn{2}{|c|}{$\Delta 2=X_{A}-X_{B}$} & $35,5^{\star \star \star}$ & $-9,9^{\star \star}$ & $41^{\star \star \star}$ & $-10,1^{\star \star}$ \\
\hline \multirow{2}{*}{\multicolumn{2}{|c|}{$\Delta 3=X_{M}-X_{B}$}} & $18^{\star \star \star}$ & $-4,2^{*}$ & $20^{\star \star \star}$ & $-7,7^{\star}$ \\
\hline & & & $\Delta \%$ & & \\
\hline \multicolumn{2}{|c|}{$\Delta 2 \%$} & 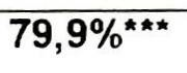 & $-24,3 \%{ }^{\star \star}$ & $110,8 \%^{\star \star \star}$ & $-21,4 \%{ }^{\star \star}$ \\
\hline \multicolumn{2}{|c|}{$\Delta 3 \%$} & $40,5 \%{ }^{\star \star \star}$ & $-10,3 \%$ & 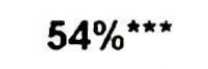 & $-16,3 \% \%^{\star \star}$ \\
\hline & & & TC & & \\
\hline tc $(\Delta$ & & 15,04 & 3,86 & 20,6 & 3,45 \\
\hline tc $(\Delta$ & & 8.14 & 1.70 & 144 & 2.08 \\
\hline
\end{tabular}

os resultados marcados com ( $\left(^{*}\right)$ são verdadeiros com $p<0,05$

os resultados marcados com ( $(*)$ ) são verdadeiros com $p<0,001$

os resultados marcados com ( $\cdots$ ) são verdadeiros com $p<0.0001$

G1 - grupo com nivel alto da FPI

G2 - grupo com nivel médio da FPI

$\mathrm{G} 3$ - grupo com nivel balxo da FPi

$\Delta$ : diferenças entre as médias

$\Delta \%$ diferenças entre as médias em porcentagem, onde $\Lambda \%=\Lambda-100 \% / \mathrm{Xb}$

FPE: Força dos Processos de Excitação do sistema nervoso do ser humano

FPI: Força dos Processos de Inibição do sistema nervoso do ser humano

M: Mobilidade do sistema nervoso

E: Equilibrio entre os processos de Excitação e da Inibição

A-T: Ansiedade-Traço

$X$ : média

S: desvio padrão

tc: valor do teste t de Student calculado 
O nivel de "A-Traço" das atacantes de meı com nivel alto da Força dos Processos da Inibição (FPI), é menor, com $p<0.05$. do que as ponteiras com baixo nivel da FPI Esta diferença é de $24.3 \%$ As atacantes com nivel alto da Força dos Processos da Inibição. possuem nivel de A-Traço 10.3\% mais baixo que as atacantes com nivel baixo de FPI Porém. este resultado não tem confiança com $p<0.05$.

O nivel de "A-Traço" das ponteıras com nivel alto da Força dos Processos da Inibição (FPI). é menor com $p<0.01$, do que as atacantes com baıxo nivel da FPI apresentando diferença de $21.4 \%$ entre atacantes com nivel alto e atacantes com nivel baıxo de FPI. As atletas com nivel médıo da Força dos Processos da Inibição possuem nivel de A-Traço mais alto, com $p<0.05$ do que as atacantes com nivel baixo da FPI. Essa diferença consıste em 16.3\%

Os resultados apresentados na TABELA 6, mostram que tanto para as ponteiras como para as centrais, com $p<0,05$, não há relação entre os niveıs de $A$ Traço e Equilibrio entre os processos da Excitação e da Inibıção do sıstema nervoso.

Porém, de um modo geral, pode-se notar que. atletas que possuem Equilibrıo entre os Processos da Excitação e da Inibıção ( $E=1.0$ - 0.1 ) apresentam tendências para algum tipo de desequilibrio (prevalência dos Processos da Excitação sobre os da Inibição ou prevalência dos Processos da Inibição sobre os da Excitação dos sistema nervoso).

Os resultados apresentado na TABELA 7, mostram que há diferença. porém não é significante com $p<0,05$, entre os niveis de A-Traço das atacantes de ponta e das atacantes de meio, diferenciados pelo nivel de Mobilidade de seu sistema nervoso. 
TABELA 6 - Comparativo estatistico entre "a-traço" e as peculiaridades tipológicas do sistema nervoso dos sujeitos com diferentes tipos de equilibrio ( $E$ ) entre os processos da excitação e os prcessos da inbição do sistema nervoso.

\begin{tabular}{|c|c|c|c|c|c|}
\hline & & \multicolumn{2}{|c|}{ PONTEIRAS } & \multicolumn{2}{|c|}{ CENTRAIS } \\
\hline \multicolumn{2}{|c|}{ NIVEIS DE "E" } & $E$ & $A-T$ & $E$ & $A-T$ \\
\hline G1 & $\begin{array}{l}X_{A} \\
S_{A}\end{array}$ & $\begin{array}{l}1.41 \\
0.11\end{array}$ & $\begin{array}{l}38,1 \\
5.7\end{array}$ & $\begin{array}{l}1,54 \\
0.14\end{array}$ & $\begin{array}{c}42.8 \\
6.36\end{array}$ \\
\hline $\mathrm{G} 2$ & $\begin{array}{l}X_{M} \\
S_{M}\end{array}$ & $\begin{array}{l}1.00 \\
0.04\end{array}$ & $\begin{array}{l}36,2 \\
4.64 \\
\end{array}$ & $\begin{array}{c}0,90 \\
0,0012\end{array}$ & $\begin{array}{r}40,1 \\
8,12 \\
\end{array}$ \\
\hline G3 & $\begin{array}{l}X_{B} \\
S_{B}\end{array}$ & $\begin{array}{l}0,78 \\
0,03 \\
\end{array}$ & $\begin{array}{l}37.9 \\
4,28 \\
\end{array}$ & $\begin{array}{l}0,59 \\
0,05 \\
\end{array}$ & $\begin{array}{l}41.4 \\
3.48 \\
\end{array}$ \\
\hline \multicolumn{6}{|c|}{$\Delta$} \\
\hline \multicolumn{2}{|c|}{$\Delta 2=X_{A}-X_{B}$} & $0,63^{\star \star \star \star}$ & 0,2 & $0,95^{\star \star \star}$ & 1,4 \\
\hline \multicolumn{2}{|c|}{$\Delta 3=X_{M}-X_{B}$} & $0,22^{\star \star \star}$ & $-1,7$ & $0,31^{\star \star \star}$ & $-1,3$ \\
\hline \multicolumn{6}{|c|}{$\Delta \%$} \\
\hline \multicolumn{2}{|c|}{$\Delta 2 \%$} & $28,2 \%^{\star \star \star}$ & $0,53 \%$ & 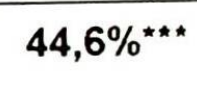 & $3,4 \%$ \\
\hline \multicolumn{2}{|c|}{$\Delta 3 \%$} & 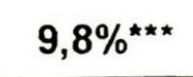 & $-4,5 \%$ & $20,8 \% \%^{\star \star \star}$ & $-3.1 \%$ \\
\hline & & & TC & & \\
\hline tc ( & & 17,5 & 0,09 & 19 & 0,61 \\
\hline tc ( & & 13,7 & 0,85 & 19.6 & 0,46 \\
\hline
\end{tabular}

os resultados marcados com ( $\cdots)$ são verdadeiros com $p<0,0001$

G1 - grupo com prevalência dos Processos da Excitaçāo sobre os Processos da Inibição dos sistema nervoso

G2 - grupo com tipo de sistema nervoso equilibrado

G3 - grupo com prevalência dos Processos da Inibiçāo sobre os Processos da Excitação do sistema nervoso

$\Lambda$ : diferenças entre as médias

$\Lambda \%$ diferenças entre as médias em porcentagem, onde $\Lambda \%=\Delta-100 \% / \mathrm{Xb}$

FPE: Força dos Processos de Excitaçăo do sistema nervoso do ser humano

FPI: Força dos Processos de Inibição do sistema nervoso do ser humano

M: Mobilidade do sistema nervoso

E: Equilibrio entre os processos de Excitação e da Inibiçâo

A-T: Ansiedade-Traço

$X$ : média

S: desvio padrão

tc: valor do teste t de Student calculado 
TABELA 7 - Comparativo estatistico entre "a-traço" e as peculıaridades tipologicas do sistema nervoso dos sujeıtos com nivel alto médıo e baixo de mobilidade ( $M$ ).

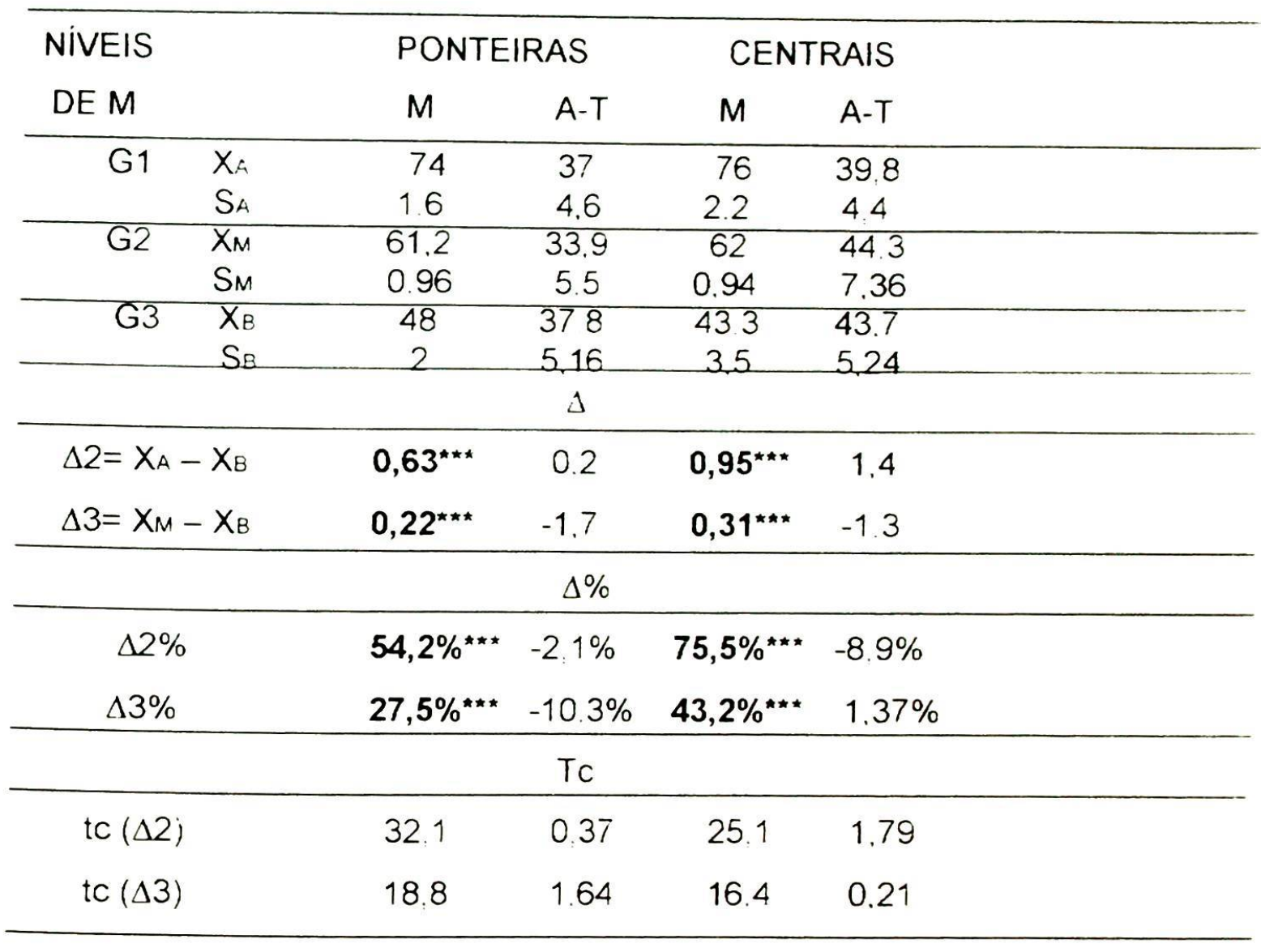

os resultados marcados com ( $\cdots)$ são verdadeıros com $p<0.0001$

G1 - grupo com prevalència dos Processos da Excitaçāo sobre os Processos da Inibiçāo dos sistema nervoso

G2 - grupo com tıpo de sistema nervoso equilibrado

G3 - grupo com prevalēncia dos Processos da Inibição sobre os Processos da Excitação do sistema nervoso $\wedge$ : diferenças entre as mèdias

$\wedge \%$ diferenças entre as medias em porcentagem, onde $\wedge \%=\Lambda-100 \% \wedge b$

FPE: Força dos Processos de Excitação do sistema nervoso do ser humano

FPI: Força dos Processos de Inibição do sistema nervoso do ser humano

M: Mobilidade do sistema nervoso

E: Equilibrio entre os processos de Excitação e da Inibição

A-T: Ansiedade-Traço

$\mathrm{X}$ : média

S: desvio padrāo

tc: valor do teste t de Student calculado 
Entretanto, observa-se que nas centrais o nivel de "A-Traço" é menor do que nas que possuem nivel médio de Mobilidade, aumentando de forma igual nas atacantes com nivel baixo e nivel alto da Mobilidade dos processos nervosos Nas ponteiras, observa-se que as atletas que possuem nivel médio de Mobilidade. apresentaram nivel alto e nivel baixo da Mobilidade.

EVANS (1979), supõe que a ansiedade esteja relacionada como tıpo de temperamento da atleta. Outros pesquisadores (PAVLOV. 1979. RODIONOV. 1973; TEMPLOV, 1961: VIATIKIN, 1978) enfatizaram que a "FPE" do sistema nervoso da atleta é a base biológica do temperamento e a Peculiaridade Tipológıca principal, e influi nas demais. Tal consideração é fortalecida com os resultados encontrados nesta pesquisa, os quais apresentam diferenças significativas entre os niveis de A-Traço de atletas com diferentes niveis de "FPE" do sistema nervoso. Tais resultados mostram ainda, que a Força dos Processos da Excitação influı nas outras peculiaridades básicas do sistema nervoso. investigadas neste estudo (Força dos Processos de Inibição, Equilibrio e Mobilidade).

\section{CONCLUSÃO}

Com base nos resultados adquiridos nesta pesquisa, pode-se concluir que:

- Quanto mais alto o nivel de Ansiedade Traço, menor é o nivel da força dos Processos de Excitação do sistema nervoso, de atletas atacantes de meio de rede e de atletas atacantes de ponta de rede.

- O nivel de ansiedade Traço das atletas centrais e atletas ponteıras. desta amostra, diminui na medida em que aumenta o nivel da Força dos Processos de Excitação de seus sistemas nervosos.

- As atacantes de ponta, desta amostra, possuem em média niveis mais elevados de Ansiedade de Traço, sendo significativamente diferentes com relação às atacantes de meio. 
- As atletas centrais possuem, em média, niveis da "FPE" de seus sistemas nervosos, mais elevado com relação às atletas ponteiras, sendo significativamente diferenciados.

- A Força dos Processos de Excitação do sistema nervoso. tem influência nas Peculiaridades Tipológicas do sistema nervoso, tais como Força dos Processos de Inibição, Equilibrio entre os processos da Excitação e da Inibıção Mobilidade destes processos e "A-Traço" ; por isso, pode ser considerada como uma peculiaridade principal do sistema nervoso do ser humano

Ainda como resultado dessas conclusões, algumas sugestōes são oferecidas como pressupostos básicos para o desenvolvımento de novos trabalhos de pesquisa

a) que estudos semelhantes sejam realizados comparando com o voleibol masculino:

b) que estudos semelhantes sejam realizados para verificar outras posıções especificas do voleibol, tais como: o levantador, o libero e os atacantes de saida de rede;

c) que estudos comparativos sejam realizados com os esportes individuais e coletivos;

d) que técnicos e atletas de voleibol façam uma reflexão critica sob a influèncıa da ansiedade traço competitivo no voleibol, estando abertos à mudanças comportamentais para essa evolução. 


\section{REFERÊNCIAS BIBLIOGRÁFICAS}

ALLPORT. G.W. Personalidade padrões e desenvolvimento São Paulo Herder 1969.

BIZZOCCHI C.E. O voleibol de alto nivel: da iniciação à competição. São Paulo Fazendo Arte Editorial, 2000

BRANDÃO M R Equipe nacional de voleibol masculino: um perfil sóciopsicológico à luz da ecologia do desenvolvimento humano. Santa Maria. 1996 Dissertação (Mestrado) - Universidade Santa Maria

CAMERON, R. The nature of effective coping and stress related problems. New York. Topline of Sports, 1980.

CATTELL. R.B. Análise cientifica da personalidade. São Paulo.IBRASA. 1975

COUOLAN, M.P. Como lidar com a ansiedade. São Paulo, Boa Forma.1992

CRATTY, B.J. Psicologia do esporte. Rio de Janeiro, Prentice Hall, 1984

DAVIDOFF, L.L. Introdução à psicologia. São Paulo,McGraw-Hill. 1983.

EAGLY, A.H.; CHAIKEN, S. The psychology of atitudes. New York. Harcourt Brace Javanovich, 1993.p.101-24.

EVANS, R. I. Construtores da psicologia. São Paulo,Summus, 1979.

EYSENCK, H. The theory os Eysenck. New York, Psychological stress, 1969 
GILL. D.L.: DEETER. T.C The relationship of competitiveness and achievement orientation to participation in sport and nowsport activities Journal of Sports \& Exercise Psychology v.10, p.139-150 1988

HACKFORT. D SCHENKMEZGER. P Anxiety. In. SINGER $R$. Handbook of research on sport psychology. New York.Mcmillan, 1993. p 328-64

IZARD C E Anxiety. New York. Academıc Press, 1982

JONES. J G. Intensity and direction as dimensions of competitive state anxiety and relationships with competitiveness. New York. Willey and Sons 1989 Cap. 2. p. 17-42.

KALININE. I. Educação fisica para a recuperação da capacidade de trabalho intelectual na sala de aula Espaços da Escola. v.3.n.9.p 47-53. 1994.

KANE, J E. Psychological aspects of sports. Penn States. HER 1970

LAWTHER. J Psicologia desportiva Rio de Janeıro.Forum. 1973

LAZARUS. R. S. Emotion and cognition. New York. Academic Press, 1985

Personalidade e adaptação 2.ed. Rio de Janeiro.Zahar.1979.

LORENZINI, G. Caracterologia y tipologia: aplicadas a la educación. 2.ed. Alcoy Marfil 1958.

LUDIN, R.W. Personalidade: uma análise do comportamento. 2.ed. São Paulo. Zahar. 1977 
MACEDO. L Comportamento agressivo em equipes femininas de futebol de salão, voleibol, hadebol e basquetebol: uma análise. São Paulo.2000 Dissertação (Mestrado) - Escola de Educação Fisıca e Esportes da Universidade de São Paulo.

MACHADO, A A. Psicologia do esporte: temas abrangentes. Jundiai Ȧpıce 1997

MAGILL, R. Aprendizagem motora: conceitos e aplicações São Paulo, Edgard Blücher .1984

MARTENS, R. SCAT. Champaign, Human Kinetics. 1977.

MARTENS, R.; VEALLEY, R.S.: BURTON D Competitive anxiety in sport. Human Kinetics, 1990.

Competitive anxiety in sport groups. Champaign. Human Kinetics 1987.

MAY, R. O significado da ansiedade. Rio de Janeiro. Zahar, 1990

McGRATH. J.E. Formulação conceitual do estresse em pesquisas. Rıo de Janeiro, Zahar, 1980.

MEDVEDEV, V.V. La preparacion psicológica de voleibolista. Cuba, Editorial Científico-Técnica, 1988. p.60-78.

NEBYLITSIN, V. D. As propriedades das bases do sistema nervoso do homem Moscou,Instrução, 1996

NOVAIS, G. Psicologia, personalidade e liderança. São Leopoldo, Rotermund. 1977. 
PAVLOV. I.P Pavlov: psicologia São Paulo Ática, 1979

PETROVISKY A V. Dicionário psicológico breve. Moscou Politisdat.1985

RODIONOV A V. A psicologia das capacidades esportivas. Moscou Cultura Fisica e Esportes 1973.

RODRIGUES A A: SIMÕES A.C: LUCATO S. Un estudio de la ansiedad en la competicion dentro de un equipo de voleibol femenino in CONGRESSO SUDAMERICANO FIEP. Córdoba. 1999 - Anais. Córdoba Diego Torres 1999 p. 70 .

SAMULSKY. DM Psicologia do esporte: teoria e aplıcação prátıca Belo Horızonte. Editora Gráfıca Costa \& Cupertıno, 1996

SHELDON, V.B. The psychological study of anxiety. Champaign Human Kinetics, 1940

SIMÕES.A.C. Equipes esportivas vistas como um micro-sistema social de rendimento entre a ideologia de liderança dos técnicos e a percepçāo real dos atletas. São Paulo,1990. Tese (Doutorado) - Escola de Educação Fisica e Esportes da Universidade de São Paulo.

SIMON, J.A Ansiedade de competição em adolescentes. Rıo de Janeiro. Zahar. 1977.

SPEILBERGER. C.D. Ansiedade como um estado emocional. Rio de Janeiro Zahar. 1980 .

Teoria da pesquisa em ansiedade. São Paulo, Zoncs, 1966 
SPEILBERGER. C.: GORSUCH, R.J.; LUSHENE, R.E. Inventário de ansiedade traço-estado - manual de psicologia aplicada. Rio de Janeiro. Cepa. 1979

STEFANELLO. J.M.F. Ansiedade competitiva e os fatores de personalidade de adolescente que praticam voleibol: um estudo causal - comparativo Kinesis, v.6 n 2, p.203-24,1990.

STRELAU, R. The inventory of Strelau. Washington, AAHPER, 1984

TAYLOR. J.A. A personality test for manifest anxiety. Journal of Psychology. $\vee 6$. n.6,p.141-45,1953

TEMPLOV B. M. Os problemas das diferenças individuais Moscou Ed ACP da Rússia. 1961

TURNER, P.E.: RAGILN J.S. Variability in competition axiety and perfomance incolege track and field athletes. Medicine and Science in Sports and Exercise, v.28,n.3.p.378-85, 1996.

VIATIKIN B.A. O papel do temperamento na atividade esportiva Moscou. Cultura Fisica e Esporte, 1978. 


\section{ANEXO I - Questionário de Ansiedade-Traço - IDATE}

\section{$\underline{\text { Instruções }}$}

Na página seguınte há um Questıonário para você responder

Trata-se de algumas afirmações que têm sido usadas para descrever sentimentos pessoais

Não há respostas certas ou erradas.

Leia com toda atenção cada uma das perguntas e assınale com circulo um dos números (1.2.3 ou 4), à direita de cada pergunta de acordo com a Instrução do alto da página

Não gaste muito tempo numa únıca afirmação mas tente dar a resposta que mais se aproxima de como você se sente geralmente

\section{Avaliação}

$\begin{array}{ll}\text { Quase sempre } 4 & \text { Às vezes....... } \\ \text { Frequentemente ......3 } & \text { Quase nunca.....1 }\end{array}$

1. Sinto-me bem 12

34

2. Canso-me facilmente 12

34

3. Tenho vontade de chorar 12

3

4

4. Gostaria de poder ser tão feliz quanto os outros parecem ser 
ANEXO I - Questionário de Ansiedade-Traço - IDATE (cont.)

5. Perco oportunidade porque não consıgo tomar

decisões. 2

3

4

6. Sinto-me descansado 12

3

4

7. Sou calmo (a). ponderado(a) e senhor(a) de mim. 12

8. Sinto que as dificuldades estão se acumulando de tal forma que não consigo resolver 12 3 4

9. Preocupo-me demais com coisas sem importância 12

10. Sou feliz 12

11. Deixo-me afetar muito pelas coisas. 12

3

4

12. Não tenho muita confiança em mim mesmo(a)...... 12

13. Sinto-me seguro(a) 12

14. Evito ter que enfrentar crises ou problemas 12 3 4

15. Sinto-me deprimido(a).

16. Estou satisfeito(a) 12

17. Às vezes, idéia sem importância me entram na cabeça e ficam-me preocupando.

18. Levo os desapontamentos tão a sério que não consigo tirá-los da cabeça. 12

3

4

19. Sou uma pessoa estável 12 3 4

20. Fico tenso(a) e perturbado(a) quando penso

em meus problemas do momento. 12 
ANEXO II - Questionárıo de Strelau

\section{Instruções}

O objetivo do presente teste é esclarecer o seu tipo e sıstema nervoso Não existem respostas certas ou erradas, uma vez que cada pessoa tem diretto a sua própria opinião. No entanto. para que possamos aconselhá-los adequadamente ao responder as questões, lembre-se

as perguntas são breves e estão contidas em todos os detalhes Imagine situaçōes típicas. não pense em detalhes. não perca tempo pensando dê a primeira resposta que Ihe vier na mente;

evite respostas indefinidas. Responda Sım ou Não

responda todas as questões sem pular nenhuma $\dot{E}$ possivel que algumas das questões descrevam situaçōes que sejam dificeıs de vocè se imaginar. Procure dar a resposta que você supõe ser a mais provável

Lembre-se de que não existem respostas boas ou ruins Não procure causar boa impressão com suas respostas. Exponha livremente a sua opnião.

1. Você facilmente estabelece contato com as pessoas?

2 Ė capaz de se abster de uma ou outra ação até o momento em que recebe as ordens correspondentes? 
3 Para recuperar as forças depois de um trabalho cansatıvo é suficıente par vocè um pequeno descanso?

4 Consegue trabalhar num meio que não oferece condições propicıas ao trabalho?

5 Nas discussões você se obtem de argumentos emocionaıs e sem relação como o objeto da dıscussão?

6 Encontra dificuldades para se absorver no trabalno depois de um longo periodo de descanso (por exemplo depois das férias)?

7 Deixa de perceber o cansaço se o trabalho o absorve inteıramente?

8 Depois de encarregar alguém de um trabalho você è capaz de pacientemente aguardar seu término?

9 Adormece com facilıdade se deitar em diferentes horas do dia?

$10 \dot{E}$ capaz de guardar segredo se isto lhe for pedido?

11 Volta facilmente a um trabalho que você já não fazia há semanas ou meses?

12. Consegue pacientemente explicar-se?

13 Gosta de trabalho que exige esforço intelectual?

14. Trabalho monótono desperta em você tédio e sonolência?

15. Adormece depois de forte tensão?

16. É capaz de se abster em caso de revelar sua superioridade?

17. Se comporta naturalmente na presença de desconhecidos?

18. É dificil par a você esconder a raiva e a ırritação?

19. Nos momentos dificeis você consegue se controlar?

20. Consegue se necessário adequar seu comportamento ao comportamento dos que the rodeiam?

21. Assume um trabalho que exige responsabilidade com boa vonatde?

22. Normalmente as pessoas que the rodeiam influenciam no seu humor? 


\section{ANEXO II - Questionárıo de Strelau (cont)}

23 É capaz de suportar uma derrota?

$24 \mathrm{Na}$ presença de pessoa cuja a opinião vocè valoriza muito. você conversa livremente como sempre?

25 Fıca irrıtado com uma mudança inesperada na sua rotına dıárıa?

26 Tem respostas prontas para tudo?

27 Se mantém calmo quando espera um decisão importante par vocè (por exemplo. o resultado do vestibular)?

28 Organıza facilmente os primeiros dıas de suas férıas?

29 Tem reações rápidas?

30. Acerta o seu andar ou suas ações com o andar ou ações de pessoas mais lentas?

31 Adormece rápido?

32 Facilmente participa de competiçōes ou resolve exercicios no quadro negro durante as aulas práticas?

33 Facilmente vocè tem seu humor estragado?

$34 \dot{E}$ dificil para você deixar um trabalho que está fazendo?

35. Consegue deixar de falar se isto atrapalha outras pessoas?

36 É fácil provocar você?

37 Tem facilidade de trabalhar com as pessoas?

38. Diante de uma situação importante você pensa bem , e suas ações?

$39 \dot{E}$ capaz de ao ler um texto seguir o raciocinio do autor do começo ao fim?

40. Conversar facilmente com seu companheiro de viagem?

41. Se abstém de demonstrar o erro do interlocutor se. por um motivo ou por outros isto não for conveniente?

42. Assume prontamente um trabalho que exige grande destreza manual?

43. É capaz de mudar uma decisão sua depois de ouvir a opnião dos outros?

44. Se acostuma rapidamente a um novo sistema de trabalho? 
ANEXO II - Questionário de Strelau (cont.)

45 É capaz de trabalhar a noite tendo já trabalhado de dia?

46. Lê rapidamente literatura (romances de ficção do tipo detetıve. espionagem, aventura, etc.)?

47. Desiste facilmente de seus planos se aparecerem dificuldades?

48. Se a situação exigir você é capaz de se controlar?

49. Acorda comumente rápido e sem dificuldades?

50 . Consegue se abster de uma reação momentânea e ımpulsıva?

51 Consegue trabalhar com barulho?

52. Ė capaz de abster quando for necessário de dizer umas verdades?

53. Consegue se manter calmo antes de exames de encontro com chefe, etc?

54. Se acostuma a um novo ambiente rapidamente?

55 . Gosta de mudanças freqüentes?

56. Recupera suas forças totalmente com o sono noturno depois de um dia de trabalho duro?

57. Evita trabalho que exige por periodos curtos de tempo atuações de diferentes espécies?

58. Resolve as dificuldades de maneira auto-suficiente?

59. Interrompe seu interlocutor?

60. Sabendo nadar, você pularia na água para salvar alguém que está se afogando?

61 É capaz de trabalhar ou estudar intensivamente?

62. É capaz de se abster de observações inconvenientes?

63. É importante para você que o seu lugar no trabalho, na sala de aula. ou a mesa seja sempre o mesmo?

64. Pode passar facilmente de um tipo de ocupação a outro?

65. Pesa todos os prós e contras antes de tomar um decisão importante?

66. Supera as dificuldades facilmente? 


\section{ANEXO II - Questionário de Strelau (cont)}

67 Lê cartas alheias revira coisas alheıas e etc.?

68. Fıca entediado durante o decorrer de ações estereotıpadas ( que decorrem de maneira sempre igual)?

69 Respeita as normas de conduta nos lugares públicos?

70 Durante uma conversa, um discursos ou resposta a uma pergunta. você se abstèm de gestos e movimentos supérfluos?

71 Gosta de ambientes anımados?

72 Gosta de atıvıdades que exigem esforço?

$73 \dot{E}$ capaz de concentrar sua atenção na realização de uma tarefa durante muito tempo?

74 Gosta de trabalho que exige movimentos rápidos?

75 Se controla em condiçōes dificeıs de vida?

76 Se for necessário você levanta assım que acorda?

$77 \dot{E}$ capaz de se necessário terminar o trabalho que Ihe fol confiado e esperar pacientemente que os outro terminem?

$78 \dot{E}$ capaz de agir como sempre depois de ter visto algo desagradável?

79. Lê os jornais diários de forma rápida?

80 Acontece as vezes, de você falar tão rápido que fica dificıl os outros Ihe entender?

$81 \dot{E}$ capaz de trabalhar normalmente não tendo dormido à noite?

82. É capaz de trabalhar um longo tempo sem um intervalo para descanso?

83. É capaz de trabalhar com dor de dente ou de cabeça?

84. $\dot{E}$ capaz de trabalhar e calmamente terminar o seu trabalho sabendo que seus companheiros se divertem ou esperam por você?

85 É comum você responder rapidamente a perguntas inesperadas?

86. Fala normalmente rápido?

87. É capaz de trabalhar calmamente se está esperando visitas?

88. Muda rapidamente de opiniāo sob a influência de argumentos irrefutáveis? 
ANEXO II - Questionário de Strelau (cont.)

89 É paciente?

90. Consegue se adaptar ao trabalho de uma pessoa mais lenta?

91. É capaz de planejar um trabalho de modo que possa realizar ao mesmo tempo várias ações compativeis?

92. Uma companhia alegre pode mudar o seu estado de espirito depressivo?

93 É capaz: sem dificuldade fazer várias coısas ao mesmo tempo?

94 Conserva o equilibrio psicológico quando é testemunna de um acidente na rua?

95. Gosta de trabalho que exige diferentes tipos de manipulação?

96 Mantém a calma quando uma pessoa intima sua sofre?

97. É auto-suficiente em situaçōes dificeis?

98. Sente-se a vontade em companhia de um grande numero de pessoas?

99. É capaz de interromper imediatamente uma conversa se for necessário ( início de uma aula, sessão de cinema. etc.)?

100. Facilmente se adapta ao método de trabalho dos outros?

101. Gosta de mudar freqüentemente o tipo de trabalho que faz?

102. Tende a tomar iniciativa se acontecer alguma coisa fora do comum?

103. Você é capaz de se abster de sorrisos inconvenientes?

104. Quando você começa a trabalhar e já de maneira intensıva?

105. Se decide a ir contra a opinião geral se você acha que está certo?

106 É capaz de superar uma depressão momentânea?

107. Adormece com dificuldade se está muito cansado de trabalho intelectual?

108. É capaz de esperar calmamente, por exemplo, a sua vez numa fila? 


\section{ANEXO II - Questionário de Strelau (cont)}

109 Se abstèm de intervir se já sabe de antemão que a intervenção não leva a nada?

110 É capaz de argumentar calmamente durante uma discussão acırrada?

111 Reage rapidamente em situação inesperada?

112 Se porta silenciosamente se isto Ihe for pedido?

113 Concorda sem grande demora em passar por procedimentos médicos dolorosos?

114 E capaz de trabalhar intensivamente?

115 Muda prontamente o seu lugar de descanso e divertimento?

$116 \dot{E}$ dificıl par você se acostumar com uma nova ordem do dia (rotına diária)?

117 Em caso de acidentes você se apressa a ajudar?

118 Se abstém de gritos e gestos ındesejáveıs emjogos esportivos. no circo, etc.?

119 Gosta de trabalho que exige conversas freqüentes com pessoas?

120 Gosta de trabalho que exige movimentos exatos e enérgicos?

121 Se considera corajoso?

122 Controla suas expressōes faciais (caretas somsos ırônicos. etc.)?

123. Perde a voz ( fala com dificuldade ) em situaçōes fora do comum?

124 É capaz de superar a desolação causada por um ınsucesso?

125 Se lhe pedirem, você é capaz de ficar calmamente muito tempo em pé (ou sentado)?

126 É capaz d reprimir sua alegria se ela magoa alguém?

127. Passa facilmente da tristeza para a alegria?

128 É fácil fazer você perder o controle de si mesmo? 
ANEXO II - Questionário de Strelau (cont.)

129. Segue sem grandes dificuldades as regras de conduta obrigatória em seu meio?

130 Gosta de falar em público?

131. Começa comumente a trabalhar rápido sem preparação muito longa?

132. Corre para ajudar alguém com rısco da próprıa vida?

133 Os seus movimentos são enérgicos?

134 Prontamente realiza um trabalho que exige responsabılidade? 
ANEXO II - Questionárıo de Strelau (cont)

Protocolo de respostas de um sujeito

Nome completo:

Data de Nascimento
Equipe

Sexo ( IM (X) F

\begin{tabular}{|c|c|c|c|c|c|c|c|c|c|c|c|}
\hline$N$ & $+^{0}-$ & $N$ & $+^{0}-$ & $N$ & $+^{0}-$ & $\mathrm{N}$ & $+^{0}$ & $N$ & $+{ }^{0}$ & $N$ & $+^{0}$ \\
\hline 1 & + & 27 & + & 53 & + & 79 & + & 105 & + & 131 & + \\
\hline 2 & - & 28 & + & 54 & + & 80 & - & 106 & + & 132 & + \\
\hline 3 & + & 29 & + & 55 & - & 81 & + & 107 & - & 133 & - \\
\hline 4 & - & 30 & + & 56 & + & 82 & + & 108 & + & 134 & + \\
\hline 5 & - & 31 & - & 57 & + & 83 & + & 109 & - & & \\
\hline 6 & - & 32 & + & 58 & + & 84 & + & 110 & + & & \\
\hline 7 & + & 33 & - & 59 & + & 85 & - & 111 & + & & \\
\hline 8 & + & 34 & + & 60 & + & 86 & - & 112 & + & & \\
\hline 9 & - & 35 & + & 61 & + & 87 & - & 113 & + & & \\
\hline 10 & + & 36 & - & 62 & + & 88 & + & 114 & + & & \\
\hline 11 & + & 37 & + & 63 & - & 89 & + & 115 & - & & \\
\hline 12 & + & 38 & + & 64 & + & 90 & + & 116 & - & & \\
\hline 13 & + & 39 & + & 65 & + & 91 & + & 117 & + & & \\
\hline 14 & + & 40 & + & 66 & + & 92 & + & 118 & + & & \\
\hline 15 & - & 41 & - & 67 & - & 93 & + & 119 & + & & \\
\hline 16 & + & 42 & + & 68 & + & 94 & + & 120 & + & & \\
\hline 17 & + & 43 & + & 69 & + & 95 & + & 121 & + & & \\
\hline 18 & - & 44 & + & 70 & - & 96 & - & 122 & + & & \\
\hline 19 & + & 45 & + & 71 & + & 97 & + & 123 & - & & \\
\hline
\end{tabular}


ANEXO II - Questionário de Strelau (cont.)

\begin{tabular}{|c|c|c|c|c|c|c|c|c|}
\hline 20 & 46 & - & 72 & + & 98 & + & 124 & + \\
\hline 21 & 47 & + & 73 & + & 99 & - & 125 & + \\
\hline 22 & 48 & + & 74 & + & 100 & + & 126 & + \\
\hline 23 & 49 & + & 75 & + & 101 & - & 127 & + \\
\hline 24 & 50 & + & 76 & + & 102 & + & 128 & - \\
\hline 25 & 51 & + & 77 & + & 103 & + & 129 & + \\
\hline 26 & 52 & - & 78 & - & 104 & + & 130 & + \\
\hline$P E=76$ & \multicolumn{4}{|c|}{$\mathrm{FPI}=66$} & $E=1,15$ & & & $1=62$ \\
\hline
\end{tabular}


ANEXO III - Análise dos resultados do estudo das peculiaridades tıpológicas e de "A$\underline{\text { Traço" }}$

TABELA 1-Resultado da investigação das peculiaridades tıpológıcas do sistema nervoso e do nivel de "a-traço" das atletas meio de rede.

\begin{tabular}{|c|c|c|c|c|c|c|c|}
\hline $\mathrm{N}^{\circ}$ & NOME & IDADE & A-Traço & FPE & FPi & $M$ & $E$ \\
\hline 01 & AAS & 20 & 37 & 70 & 54 & 74 & 1.30 \\
\hline 02 & $A C$ & 29 & 50 & 52 & 70 & 54 & 0.74 \\
\hline 03 & $A D$ & 17 & 35 & 54 & 46 & 52 & 1.17 \\
\hline 04 & AJGS & 22 & 38 & 66 & 60 & 72 & 1.10 \\
\hline 05 & AOS & 23 & 28 & 69 & 82 & 70 & 0.84 \\
\hline 06 & ASM & 19 & 36 & 76 & 72 & 62 & 1.06 \\
\hline 07 & ASM & 19 & 36 & 76 & 72 & 62 & 1.06 \\
\hline 08 & $B G$ & 22 & 28 & 80 & 64 & 72 & 1.25 \\
\hline 09 & BK & 21 & 28 & 71 & 86 & 57 & 0.83 \\
\hline 10 & $C K L$ & 18 & 41 & 58 & 62 & 50 & 0.94 \\
\hline 11 & DA & 20 & 35 & 60 & 60 & 72 & 1.00 \\
\hline 12 & $\mathrm{DD}$ & 19 & 39 & 78 & 62 & 62 & 1.26 \\
\hline 13 & DFS & 18 & 38 & 70 & 50 & 70 & 1.40 \\
\hline 14 & DPR & 18 & 30 & 68 & 82 & 60 & 0.83 \\
\hline 15 & DRM & 19 & 30 & 82 & 82 & 64 & 1.00 \\
\hline 16 & DS & 20 & 22 & 66 & 66 & 54 & 1.00 \\
\hline 17 & DT & 19 & 46 & 61 & 76 & 53 & 0.80 \\
\hline 18 & EC & 23 & 34 & 58 & 72 & 63 & 0,81 \\
\hline 19 & ECM & 21 & 33 & 48 & 62 & 46 & 0.77 \\
\hline 20 & EDD & 26 & 20 & 84 & 78 & 68 & 1,08 \\
\hline 21 & EGDJr & 20 & 33 & 76 & 78 & 48 & 0.97 \\
\hline 22 & EREL & 20 & 38 & 54 & 46 & 62 & 1.17 \\
\hline 23 & ES & 23 & 44 & 56 & 57 & 60 & 0.98 \\
\hline 24 & $\mathrm{FA}$ & 20 & 49 & 55 & 47 & 63 & 1,17 \\
\hline & & 21,81 & 35,68 & 63.05 & 62.45 & 60.89 & 1,04 \\
\hline PD. & ÉDIO & 2,42 & 5.48 & 8,11 & 9,56 & 7 & 0,16 \\
\hline
\end{tabular}


ANEXO III - Análise dos resultados do estudo das peculiaridades tipológicas e de "ATraço"

FPE: Força dos Processos de Excitação do sistema nervoso dos individuos

FPI: Força dos Processos de Inibição do sistema nervoso dos individuos

M: Mobilidade do sistema nervoso dos individuos

E: Equilibrio entre os processos de Excitação e Inibıção do sıstema nervoso dos individuos

A-Traço: Nivel de Ansiedade de Traço dos individuos 
ANEXO III - Análise dos resultados do estudo das peculiaridades tipológicas e de "ATraço"

TABELA 2 -Resultado da investigação das peculiarıdades tipológicas do sistema nervoso e do nivel de "a-traço" das atletas atacantes de ponta

\begin{tabular}{|c|c|c|c|c|c|c|c|}
\hline$N^{\circ}$ & NOME & IDADE & A-Traço & FPE & FPI & $M$ & $E$ \\
\hline 01 & $\mathrm{FF}$ & 23 & 36 & 49 & 52 & 62 & 094 \\
\hline 02 & $A R$ & 24 & 46 & 58 & 48 & 66 & 121 \\
\hline 03 & $A A$ & 19 & 44 & 64 & 67 & 65 & 0.96 \\
\hline 04 & $A A C$ & 22 & 41 & 67 & 48 & 66 & 140 \\
\hline 05 & $A B$ & 20 & 27 & 64 & 76 & 52 & 0.84 \\
\hline 06 & $A F$ & 19 & 45 & 42 & 56 & 68 & 0.75 \\
\hline 07 & AFW & 19 & 41 & 54 & 40 & 44 & 135 \\
\hline 08 & $A G$ & 19 & 48 & 45 & 56 & 72 & 1.53 \\
\hline 09 & $A M$ & 21 & 36 & 69 & 56 & 76 & 123 \\
\hline 10 & $A M$ & 19 & 50 & 61 & 63 & 64 & 0.97 \\
\hline 11 & $A P$ & 24 & 34 & 80 & 68 & 81 & 1.18 \\
\hline 12 & APB & 19 & 54 & 48 & 44 & 40 & 1.20 \\
\hline 13 & APR & 21 & 44 & 58 & 76 & 73 & 1.32 \\
\hline 14 & $A R$ & 20 & 40 & 46 & 60 & 46 & 0.61 \\
\hline 15 & ATA & 20 & 45 & 28 & 54 & 40 & 041 \\
\hline 16 & $\mathrm{CC}$ & 21 & 40 & 38 & 60 & 60 & 0.63 \\
\hline 17 & $\mathrm{CHB}$ & 19 & 35 & 54 & 54 & 56 & 100 \\
\hline 18 & CM & 18 & 45 & 42 & 54 & 54 & 0.78 \\
\hline 19 & CR & 21 & 43 & 51 & 58 & 57 & 0.88 \\
\hline & & 20,74 & 42,07 & 55,92 & 57,1 & 60.5 & 1.01 \\
\hline$P D$ & & 1,75 & 6,05 & 9,943 & 9,43 & $8: 12$ & 0.21 \\
\hline
\end{tabular}


ANEXO III - Análise dos resultados do estudo das peculiaridades tipológicas e de "A.

\section{Traço"}

FPE: Força dos Processos de Excitação do sistema nervoso dos ındividuos

FPI: Força dos Processos de Inibição do sistema nervoso dos individuos

M: Mobilidade do sistema nervoso dos individuos

E: Equilibrio entre os processos de Excitação e Inibição do sistema nervoso dos individuos

A-Traço: Nivel de Ansiedade de Traço dos individuos 
ANEXO IV - Formação de grupos, segundo o nivel da força dos processos da excitação do sistema nervoso

TABELA 1 - Atacantes de meıo de rede com nivel alto de FPE de seu sistema nervoso

\begin{tabular}{lcccccc}
\hline$N^{\circ}$ Nome & Idade & FPE & FPI & M & E & A-Traço \\
\hline 01 BDD & 26 & 84 & 78 & 68 & 1.08 & 20 \\
02 DRM & 19 & 82 & 82 & 64 & 1.00 & 30 \\
03 BG & 22 & 80 & 61 & 72 & 1.25 & 28 \\
04 DD & 19 & 78 & 62 & 62 & 1.26 & 39 \\
05 SP & 25 & 78 & 80 & 76 & 0.98 & 36 \\
06 VG & 21 & 77 & 69 & 68 & 1.12 & 36 \\
07 ASM & 19 & 76 & 72 & 62 & 1.06 & 36 \\
08 EGDRJr & 20 & 76 & 78 & 48 & 0.97 & 33 \\
\hline MÉDIA & & & & & & \\
DESV. PD MÉDIO & 21.2 & 78.33 & 71.7 & 64.8 & 1.10 & 30.8 \\
\hline
\end{tabular}


ANEXO IV - Formação de grupos, segundo o nivel da força dos processos da excitação do sistema nervoso (cont.)

TABELA 2 - Atacantes de meio de rede com nivel médio de FPE de seu sistema nervoso.

\begin{tabular}{llccccccc}
$N^{*}$ & Nome & Idade & FPE & FPI & M & E & A-Traço \\
\hline 01 & OJB & 22 & 66 & 48 & 70 & 1.38 & 37 \\
02 & MV & 18 & 65 & 73 & 76 & 0.89 & 37 \\
03 & LF & 21 & 64 & 68 & 54 & 0.94 & 27 \\
04 & RMS & 21 & 61 & 62 & 50 & 1.03 & 31 \\
OS & RP & 23 & 64 & 66 & 71 & 0.97 & 30 \\
06 & GC & 20 & 62 & 98 & 66 & 1.19 & 36 \\
W & MT & 22 & 62 & 68 & 60 & 0.91 & 31 \\
O8 & MVC & 20 & 62 & 72 & 62 & 0.86 & 27 \\
\hline MÉDIA & MESV. PD. MÉDIO & 100 & 1,3 & 9,56 & 7,3 & 0.19 & 4.96 \\
\hline
\end{tabular}


ANEXO IV - Formação de grupos, segundo o nivel da força dos processos da excitação do sistema nervoso (cont.)

TABELA 3 - Atacantes de meio de rede com nivel baixo de FPE de seu sistema nervoso

\begin{tabular}{|c|c|c|c|c|c|c|c|}
\hline $\mathrm{N}^{\circ}$ & Nome & Idade & FPE & FPI & $M$ & $E$ & A-Traço \\
\hline 01 & MLMK & 20 & 32 & 54 & 62 & 0.96 & 40 \\
\hline 02 & NM & 25 & 32 & 73 & 50 & 0.71 & 37 \\
\hline 03 & TC & 21 & 52 & 46 & 95 & 1.73 & 92 \\
\hline 04 & LL & 18 & 50 & 52 & 56 & 0.96 & 39 \\
\hline 05 & RAT & 23 & 50 & 62 & 54 & 0.81 & 44 \\
\hline 06 & $\mathrm{RSH}$ & 34 & 50 & 70 & 54 & 0.71 & 39 \\
\hline 07 & $R \mathrm{~L}$ & 21 & 49 & 92 & 98 & 7.17 & 36 \\
\hline 08 & ECM & 21 & 98 & 62 & 46 & 0.77 & 33 \\
\hline \multicolumn{2}{|c|}{ MÉDIA } & 20,389 & 49,3 & 56,9 & 54.2 & 0,89 & 38.3 \\
\hline \multicolumn{2}{|c|}{ DESV. PD MÉDIO } & 1,9196 & 2,09 & 7,88 & 5,44 & 0,13 & 2.64 \\
\hline
\end{tabular}

FPE: Força dos Processos de Excitação do sistema nervoso dos individuos

FPI: Força dos Processos de Inibição do sistema nervoso dos individuos

M: Mobilidade do sistema nervoso dos individuos 
ANEXO IV - Formação de grupos, segundo o nivel da força dos processos da excitação do sistema nervoso (cont.)

TABELA 4 - Atacantes de meio de rede com nivel alto de FPE de seu sistema nervoso

\begin{tabular}{|c|c|c|c|c|c|c|c|}
\hline $\mathrm{N}^{\circ}$ & Nome & Idade & FPE & FPI & $M$ & $E$ & A-Traço \\
\hline 01 & $A P$ & 24 & 80 & 68 & 81 & 1.18 & 34 \\
\hline 02 & VP & 19 & 79 & 59 & 66 & 1,34 & 34 \\
\hline 03 & $\mathrm{RL}$ & 18 & 77 & 62 & 79 & 1.24 & 43 \\
\hline 04 & DR & 21 & 76 & 86 & 74 & 0.88 & 38 \\
\hline 05 & FP & 19 & 76 & 86 & 70 & 0.90 & 30 \\
\hline 06 & LS & 79 & 76 & 48 & 70 & 1.58 & 35 \\
\hline 07 & LW & 18 & 76 & 72 & 74 & 1.06 & 40 \\
\hline 08 & MF & 25 & 76 & 86 & 79 & 0.88 & 29 \\
\hline \multicolumn{2}{|c|}{ MÉDIA } & 20,3 & 75,9 & 69,1 & 72,7 & 1,14 & 354 \\
\hline \multicolumn{2}{|c|}{ DESV. PD MÉDIO } & 1,96 & 1,76 & 10,9 & 4,7 & 0.2 & 4.08 \\
\hline
\end{tabular}


ANEXO IV - Formação de grupos, segundo o nivel da força dos processos da excitação do sistema nervoso (cont.)

TABELA 5 - Atacantes de meıo de rede com nivel médio de FPE de seu sistema nervoso

No Nome Idade FPE FPI M E A-Traço

$\begin{array}{llllllll}01 & \text { DDC } & 19 & 56 & 60 & 58 & 0.93 & 37 \\ 02 & \text { PGG } & 18 & 56 & 50 & 60 & 1.12 & 40 \\ 03 & \text { NH } & 20 & 55 & 39 & 66 & 1.41 & 34 \\ 04 & \text { AA } & 26 & 54 & 70 & 50 & 0.77 & 45 \\ 05 & \text { AFW } & 19 & 54 & 40 & 44 & 1.35 & 41 \\ 06 & \text { CHB } & 19 & 54 & 54 & 56 & 1.00 & 35 \\ 07 & \text { EO } & 22 & 54 & 56 & 68 & 0.96 & 60 \\ 08 & \text { LB } & 21 & 59 & 61 & 42 & 0.89 & 48\end{array}$

$\begin{array}{lllllll}\text { MÉDIA } & 10,2 & 54,5 & 53,8 & 537 & 7,04 & 42.3\end{array}$

$\begin{array}{lllllll}\text { DESV. PAD MÉDIO } & 1,68 & 0.7 & 7,24 & 8.56 & 0.16 & 5.36\end{array}$


ANEXO IV - Formação de grupos, segundo o nivel da força dos processos da excitação do sistema nervoso (cont.)

TABELA 6 - Atacantes de meio de rede com nivel baixo de FPE de seu sistema nervoso

\begin{tabular}{llcccccc}
$N^{\circ}$ & Nome & Idade & FPE & FPI & M & E & A-Traço \\
\hline 01 & CM & 18 & 42 & 54 & 54 & 0.78 & 45 \\
02 & GC & 21 & 38 & 60 & 60 & 0.63 & 40 \\
03 MAB & 22 & 38 & 42 & 50 & 0.90 & 63 \\
04 & LV & 23 & 37 & 57 & 41 & 0.65 & 41 \\
OS LALS & 20 & 36 & 48 & 50 & 0.75 & 45 \\
06 & FM & 27 & 35 & 42 & 52 & 0.83 & 43 \\
07 & LCH & 20 & 34 & 54 & 58 & 0.63 & 42 \\
08 & ATA & 20 & 18 & 68 & 40 & 0.41 & 45 \\
\hline MÉDIA & 20,2 & 34,3 & 52,4 & 52 & 0,67 & 45.2 \\
DESV.PD.MÉDIO & 1.24 & 4,04 & 6,2 & 5.4 & 0,12 & 4,32 \\
\hline
\end{tabular}

FPE: Força dos Processos de Excitação do sistema nervoso dos individuos FPI: Força dos Processos de Inibição dos sistema nervoso dos individuos M: Mobilidade do sistema nervoso dos individuos

E: Equilibrio entre os processos de Excitação e Inibição do sistema nervoso dos individuos 
ANEXO V - Formação dos Grupos. segundo o nivel da força dos processos de inibição do sistema nervoso.

TABELA 1 - Grupo composto por atletas atacantes de meio, com nivel alto da forca dos processos de inibição do sistema nervoso

No Nome Idade FPI FPE M E A-Traço

$\begin{array}{llllllll}01 & \text { BK } & 21 & 86 & 71 & 57 & 0,83 & 28\end{array}$

$\begin{array}{llllllll}02 & \text { AOS } & 23 & 82 & 69 & 70 & 0.89 & 28\end{array}$

$\begin{array}{llllllll}03 & \text { DPR } & 18 & 82 & 68 & 60 & 0.83 & 30\end{array}$

$\begin{array}{llllllll}04 & \text { DRM } & 19 & 82 & 82 & 64 & 1.00 & 30\end{array}$

$\begin{array}{llllllll}05 & \text { RS } & 38 & 81 & 73 & 67 & 0,90 & 21\end{array}$

$\begin{array}{llllllll}06 & \text { SP } & 25 & 80 & 78 & 76 & 0.98 & 36\end{array}$

$\begin{array}{llllllll}07 & \text { EDD } & 26 & 78 & 84 & 68 & 1.08 & 20\end{array}$

$\begin{array}{llllllll}08 & \text { EGDJr. } & 20 & 78 & 76 & 48 & 0.97 & 33\end{array}$

$\begin{array}{lllllll}\text { MÈDIA } & 23,3 & 79,9 & 72,2 & 62 & 0,90 & 30,9\end{array}$

$\begin{array}{lllllll}\text { DESV.PD. MÉDIO } & 3,96 & 2,72 & 6,4 & 7 & 0,082 & 5,68\end{array}$ 
TABELA 2 - Grupo composto por atletas atacantes de meı. com nivel médıo da Força dos Processos de Inibıção do Sistema Nervoso

No Nome Idade FPI FPE $M$ E A-Traço

$\begin{array}{llllllll}01 & \text { BG } & 22 & 64 & 80 & 72 & 125 & 28 \\ 02 & \text { ZC } & 25 & 64 & 68 & 64 & 106 & 31 \\ 03 & \text { LI } & 21 & 63 & 71 & 69 & 1.13 & 37 \\ 09 & \text { CKL } & 18 & 62 & 58 & 50 & 0.94 & 41 \\ \text { OS } & \text { DD } & 19 & 62 & 78 & 62 & 1.26 & 39 \\ 06 & \text { ECM } & 27 & 62 & 48 & 46 & 0.77 & 33 \\ 07 & \text { NRH } & 19 & 62 & 68 & 79 & 710 & 34 \\ 08 & \text { RAT } & 23 & 62 & 50 & 54 & 1.10 & 44\end{array}$

MÉDIA

23.3

629692

$59.3 \quad 1.06$

36.6

DESV.PD MÉDIO

1.9

0,76

8,8

8.9

011

52 
$\begin{aligned} \text { ANEXO V - Formação dos Grupos, segundo o nivel da força dos processos de } & \text { inibição do sistema nervoso. (cont) } \\ & \text { inger }\end{aligned}$

TABELA 3 - Grupo composto por atletas atacantes de meıo com nivel baixo da força dos processos de inibição do sistema nervoso

\begin{tabular}{llllllll}
$N^{\circ}$ & Nome & Idade & FPI & FPE & M & E & A-Traço \\
\hline 01 & OJB & 22 & 48 & 66 & 70 & 1.38 & 37 \\
02 & FA & 20 & 47 & 55 & 63 & 1,17 & 99 \\
03 & AD & 17 & 46 & 54 & 52 & 1.17 & 35 \\
09 & EREL & 20 & 46 & 54 & 62 & 117 & 38 \\
OS & TC & 21 & 46 & 52 & 46 & 1,13 & 42 \\
06 & JLS & 13 & 43 & 58 & 68 & 1.35 & 46 \\
07 & NF & 21 & 43 & 62 & 76 & 1.49 & 48 \\
08 & RBS & 19 & 42 & 68 & 72 & 1,62 & 29 \\
\hline MÉDIA & 20,06 & 44,4 & 58,9 & 63,3 & 1,33 & 40.8 \\
DESV. PAD.MÉDIO & 7,28 & 2,2 & 6,28 & 9,1 & 0,17 & 5,8 \\
\hline
\end{tabular}

FPE: Força dos Processos de Excitação do sistema nervoso dos individuos

FPI: Força dos Processos de Inibição dos sistema nervoso dos individuos

M: Mobilidade do sistema nervoso dos indivíduos 
ANEXO V - Formação dos Grupos, segundo o nivel da forca dos processos de inibição do sistema nervoso. (cont.)

TABELA 4 - Grupo composto por atletas atacantes de ponta, com nivel alto da força dos processos de inibição do sistema nervoso.

$N^{\circ} \quad$ Nome Idade FPI FPE M E A-Traço

$\begin{array}{lllllllll}01 & \text { DR } & 21 & 86 & 76 & 74 & 0,88 & 38\end{array}$

$\begin{array}{llllllll}02 & \text { MF } & 25 & 86 & 76 & 79 & 0.88 & 29\end{array}$

$\begin{array}{llllllll}03 & \text { FP } & 19 & 84 & 76 & 70 & 0,90 & 30\end{array}$

$\begin{array}{llllllll}04 & \text { SSO } & 19 & 78 & 46 & 48 & 0.59 & 37\end{array}$

$\begin{array}{llllllll}05 & \mathrm{AB} & 20 & 76 & 64 & 52 & 0,84 & 27\end{array}$

$\begin{array}{llllllll}\text { O6 } & \text { AR } & 20 & 76 & 46 & 46 & 0.61 & 40\end{array}$

$\begin{array}{llllllll}07 & \text { LP } & 20 & 76 & 52 & 60 & 0.68 & 40\end{array}$

$\begin{array}{llllllll}\text { OB } & \text { DP } & 19 & 72 & 44 & 70 & 0.94 & 47\end{array}$

$\begin{array}{lllllll}\text { MÉDIA } & 20 & 78 & 62 & 63 & 0,79 & 37\end{array}$

DESV. PAD. MEDIO 1,16 $4,56 \quad 11,92 \quad 9,3 \quad 0,14 \quad 6,2$ 
ANEXO V - Formação dos Grupos segundo o nivel da força dos processos de inıbição do sistema nervoso. (cont.)

TABELA 5 - Grupo composto por atletas atacantes de ponta com nivel médıo da força dos processos de inibıção do sıstema nervoso

No Nome Idade FPI FPE M E A-Traço

$\begin{array}{llllllll}01 & \text { VP } & 19 & 59 & 79 & 66 & 1.34 & 34 \\ 02 & \text { CR } & 21 & 58 & 51 & 57 & 0.88 & 43 \\ 03 & \text { JD } & 20 & 58 & 65 & 71 & 1.72 & 26 \\ 04 & \text { MG } & 20 & 58 & 50 & 62 & 0.86 & 46 \\ 05 & \text { RF } & 20 & 58 & 45 & 54 & 0.78 & 48 \\ \text { O6 } & \text { SL } & 20 & 58 & 54 & 36 & 0.93 & 40 \\ 07 & \text { LV } & 23 & 57 & 37 & 41 & 0.65 & 41 \\ \text { OB } & \text { AF } & 19 & 56 & 42 & 68 & 0.75 & 45\end{array}$

MÉDIA

20

57

$\begin{array}{llll}55 & 60 & 0.96 & 39,4\end{array}$

DESV.PAD.MEDIO 0.82

0,92

10.44

10

$0.18 \quad 5.32$ 
ANEXO V - Formação dos Grupos segundo o nivel da força dos processos de inıbição do sistema nervoso. (cont.)

TABELA 6 - Grupo composto por atletas atacantes de ponta, com nivel baixo da força dos processos de inibıção do sıstema nervoso.

No Nome Idade FPI FPE M E A-Traço

\begin{tabular}{llllllll}
01 & FM & 21 & 42 & 35 & 52 & 0.83 & 43 \\
02 & MAB & 20 & 42 & 38 & 50 & 0.90 & 63 \\
03 & AFW & 19 & 40 & 54 & 94 & 1.35 & 47 \\
04 & APB & 19 & 40 & 48 & 90 & 1.20 & 54 \\
05 & DN & 19 & 40 & 58 & 68 & 1.45 & 57 \\
O6 & MH & 20 & 39 & 55 & 66 & 1.41 & 34 \\
07 & LGC & 18 & 36 & 48 & 62 & 1.33 & 48 \\
08 & SE & 15 & 34 & 70 & 74 & 2.06 & 40 \\
\hline & & 19 & 37 & 50 & 58 & 1.38 & 47.1 \\
MÉDIA & & & & & & & \\
DESV.PAD.MEDIO & 0.62 & 4.32 & 7.72 & 10.8 & 0.25 & 6.9 \\
\end{tabular}

FPE: Força dos Processos de Excitação do sistema nervoso dos individuos FPI: Força dos Processos de Inibição dos sistema nervoso dos individuos M: Mobilidade do sistema nervoso dos individuos 
ANEXO V - Formação dos Grupos segundo o nivel da força dos processos de inibição do sistema nervoso. (cont)

E: Equilibrıo entre os processos de Excıtação e Inibıção do sıstema nervoso dos individuos

A-Traço: Nivel de Ansiedade de Traço dos ındıviduos 
ANEXO VI - Formação dos grupos, segundo o nivel da mobilidade de sıstema nervoso

TABELA 1 - Grupo composto por atletas atacantes de meio com nivel alto da mobilidade do sistema nervoso.

No Nome Idade FPI FPE $M$ E A-Traço

\begin{tabular}{llllllll}
01 & MV & 18 & 76 & 65 & 73 & 0.89 & 37 \\
02 & NF & 21 & 76 & 62 & 43 & 1.44 & 48 \\
03 & RM & 22 & 76 & 71 & 41 & 1.73 & 48 \\
04 & SP & 25 & 76 & 78 & 80 & 0.98 & 36 \\
05 & AAS & 20 & 79 & 70 & 54 & 1.30 & 37 \\
06 & HRH & 19 & 74 & 68 & 62 & 1.10 & 34 \\
07 & AJGS & 22 & 72 & 66 & 60 & 1.10 & 38 \\
08 & BG & 22 & 72 & 80 & 64 & 1.25 & 28 \\
& & & & & & & \\
\hline \\
MEDIA
\end{tabular}


ANEXO VI - Formação dos grupos, segundo o nivel da mobilidade de sıstema nervoso (cont.)

TABELA 2 - Grupo composto por atletas atacantes de meio com nivel médıo da mobilidade do sistema nervoso.

No Nome Idade FPI FPE M E A-Traço

01

$\begin{array}{lllllll}\text { ASM } & 19 & 62 & 76 & 72 & 1.06 & 36\end{array}$

02

DD

19

$62 \quad 78$

$\begin{array}{lll}62 & 1.26 & 39\end{array}$

03

EREL

20

62

54

$\begin{array}{lll}46 & 1.17 \quad 38\end{array}$

04 MLMK

20

62

52

$\begin{array}{lll}54 & 0.96 \quad 40\end{array}$

05 MVC

20

61

62

$\begin{array}{lll}72 & 0.86 & 27\end{array}$

06 RTMA

22

$62 \quad 76$

$\begin{array}{lll}66 & 115 \quad 25\end{array}$

07 DPR

18

$60 \quad 68$

$\begin{array}{lll}82 & 0.83 \quad 30\end{array}$

08

23

23

$60 \quad 56$

$\begin{array}{lll}57 & 0.98 & 44\end{array}$

MÉDIA

20,5

61,2

64,6

$65,3 \quad 1,00 \quad 33,9$

DESV. PD MÉDIO 1,4

0,96

7,92

$8,44 \quad 0,12 \quad 5,5$ 
ANEXO VI - Formação dos grupos, segundo o nivel da mobilidade de sıstema nervoso (cont.)

TABELA 3 - Grupo composto por atletas atacantes de meı. com nivel baıxo da mobilidade do sistema nervoso.

$N^{\circ} \quad$ Nome Idade $M$ FPI FPE $E$ A-Traço

\begin{tabular}{lccccccc}
\hline 01 & $\mathrm{VN}$ & 23 & 52 & 57 & 61 & 0.93 & 48 \\
02 & $\mathrm{CKL}$ & 18 & 50 & 58 & 62 & 0.94 & 41 \\
03 & $\mathrm{NM}$ & 25 & 50 & 52 & 73 & 0.71 & 37 \\
04 & $\mathrm{RMS}$ & 21 & 50 & 64 & 62 & 1.03 & 31 \\
05 & $\mathrm{EGD}$ & 10 & 48 & 76 & 78 & 0.97 & 33 \\
06 & $\mathrm{MSM}$ & 20 & 48 & 54 & 66 & 0.82 & 31 \\
07 & $\mathrm{RL}$ & 21 & 48 & 49 & 42 & 1,17 & 36 \\
08 & ECM & 21 & 46 & 48 & 62 & 0.77 & 33 \\
\hline & & & & & & & \\
MÉDIA & & 20,88 & 48 & 56,6 & 60,2 & 0.96 & 37,8 \\
DESV.PD MÉDIO & 1,48 & 2 & 5,72 & 8,52 & 0,12 & 5,16 \\
\hline
\end{tabular}

FPE: Força dos Processos de Excitação do sistema nervoso dos individuos FPI: Força dos Processos de Inibição do sistema nervoso dos indivíduos

M: Mobilidade do sistema nervoso dos individuos 
ANEXO VI - Formação dos grupos, segundo o nivel da mobilidade de sistema nervoso (cont.)

TABELA 4 - Grupo composto por atletas atacantes de ponta, com nivel alto da mobilidade do sistema nervoso

$N^{\circ} \quad$ Nome Idade $M$ FPI FPE $E$ A-Traço

$\begin{array}{llllllll}01 & \text { AP } & 24 & 81 & 80 & 68 & 1.18 & 34 \\ 02 & \text { MF } & 25 & 79 & 76 & 86 & 0.88 & 29 \\ 03 & \text { RL } & 18 & 79 & 77 & 62 & 1.24 & 43 \\ 04 & \text { AM } & 21 & 76 & 69 & 56 & 1.23 & 36 \\ 05 & \text { FS } & 22 & 75 & 60 & 48 & 1.25 & 48 \\ 06 & \text { DR } & 21 & 74 & 76 & 86 & 0.88 & 38 \\ 07 & \text { LFS } & 22 & 74 & 68 & 67 & 1.01 & 46 \\ 08 & \text { LW } & 18 & 74 & 70 & 34 & 2.06 & 40\end{array}$

$\begin{array}{lllllll}\text { MÉDIA } & 20.8 & 76 & 71,6 & 649 & 117 & 39.8\end{array}$

$\begin{array}{lllllll}\text { DESV.PD MÉDIO } \quad 2,04 & 2: 2 & 5,4 & 11,92 & 0,221 & 4,44\end{array}$ 
ANEXO VI - Formação dos grupos, segundo o nivel da mobilidade de sistema nervoso (cont.)

TABELA 5 - Grupo composto por atletas atacantes de ponta com nivel medio da mobilidade do sistema nervoso.

No Nome Idade M FPI FPE $E$ A-Traço

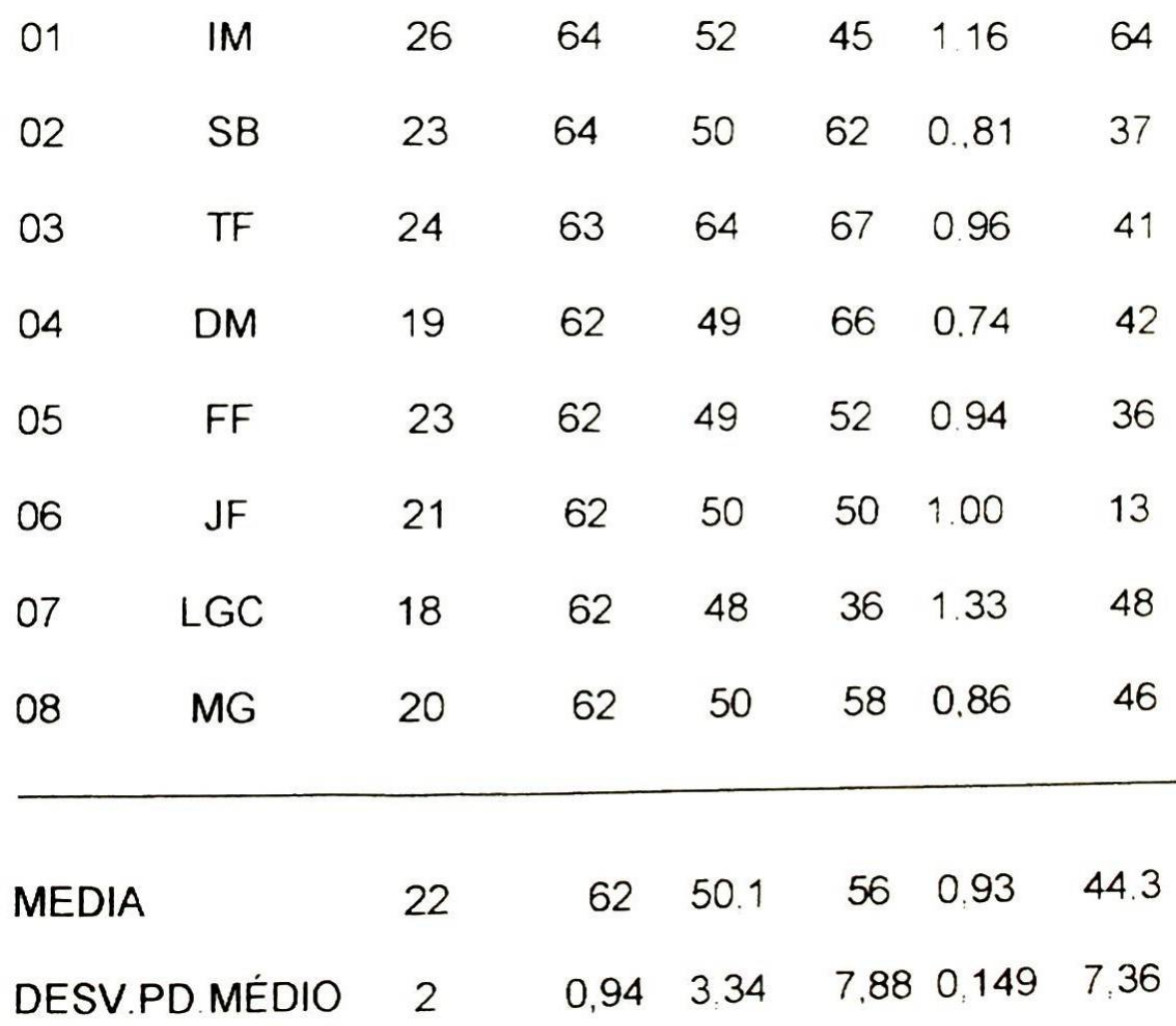


ANEXO VI - Formação dos grupos, segundo o nivel da mobilidade de sıstema nervoso. (cont.)

TABELA 6 - Grupo composto por atletas atacantes de ponta com nivel baıxo da mobilidade do sistema nervoso

No Nome Idade $M$ FPI FPE $E$ A-Traço

\begin{tabular}{llllllll}
01 & DM & 19 & 48 & 44 & 26 & 1.69 & 43 \\
02 & EZ & 21 & 48 & 44 & 50 & 0.88 & 54 \\
03 & SSO & 19 & 48 & 46 & 78 & 0.59 & 37 \\
04 & AR & 20 & 46 & 46 & 76 & 0.61 & 40 \\
05 & AFW & 19 & 49 & 54 & 40 & 1.35 & 41 \\
06 & JB & 12 & 54 & 67 & 61 & 0,89 & 48 \\
07 & LV & 23 & 41 & 37 & 57 & 0.65 & 47 \\
08 & APB & 19 & 40 & 48 & 40 & 1.20 & 54 \\
& & & & & & & \\
\hline MÉDIA & & 20,1 & 43,3 & 45,5 & 55,4 & 0.92 & 43.7 \\
DESV.PD.MÉDIO & 0,94 & 3,5 & 5,8 & 13,12 & 0,299 & 5,24
\end{tabular}

FPE: Força dos Processos de Excitação do sistema nervoso dos individuos FPI: Força dos Processos de Inibição do sistema nervoso dos individuos 
ANEXO VI - Formação dos grupos, segundo o nivel da mobilidade de sıstema nervoso. (cont.)

M: Mobilidade do sistema nervoso dos individuos

E: Equilibrio entre os processos de Excitação e Inibição do sıstema nervoso dos individuos

A-Traço: Nivel de Ansiedade de Traço dos individuos 
ANEXO VII - Formação dos grupos segundo o equilibrıo entre os processos da excitação e os processos de inibıção do sıstema nervoso.

TABELA 1 - Grupo composto por atletas atacantes de meı com prevalência dos processos da excitação sobre os processos da inibição do sistema nervoso.

$N^{\circ} \quad$ Nome Idade $E$ FPE FPI M A-Traço

$\begin{array}{llllllll}01 & \text { RM } & 22 & 1,73 & 71 & 41 & 76 & 48 \\ 02 & \text { RBB } & 19 & 1,62 & 68 & 42 & 72 & 29 \\ 03 & \text { NF } & 21 & 1,44 & 62 & 43 & 76 & 98 \\ 04 & \text { DFS } & 18 & 1.40 & 70 & 50 & 70 & 38 \\ 05 & \text { OJB } & 22 & 1,38 & 66 & 48 & 70 & 37 \\ 06 & \text { JLS } & 23 & 1,35 & 58 & 43 & 68 & 46 \\ 07 & \text { VF } & 13 & 1,33 & 76 & 57 & 65 & 23 \\ 08 & \text { AAS } & 20 & 1,30 & 70 & 54 & 74 & 37\end{array}$

$\begin{array}{lllllll}\text { MÉDIA } & 21 & 1,41 & 68 & 49 & 70 & 38,1\end{array}$

DESV.PD.MÉDIO $\quad 1,5 \quad 0,11 \quad 4,9 \quad 06 \quad 3,72 \quad 5,72$ 
ANEXO VII - Formação dos grupos segundo o equilibrio entre os processos da excitação e os processos de inibição do sistema nervoso. (cont.)

TABELA 2 - Grupo composto por atletas atacantes de meio. com tipo de sistema nervoso equilibrado.

$N^{\circ} \quad$ Nome Idade $E$ FPE FPI M A-Traço

\begin{tabular}{lccccccc}
\hline 01 & RMS & 21 & 31 & 64 & 62 & 50 & 1.03 \\
02 & ES & 23 & 44 & 56 & 57 & 60 & 0.98 \\
03 & ASM & 19 & 36 & 76 & 72 & 62 & 1.06 \\
04 & EGDJr. & 20 & 33 & 76 & 78 & 48 & 0,97 \\
05 & MLMK & 20 & 40 & 52 & 54 & 62 & 0,96 \\
06 & LL & 18 & 39 & 50 & 52 & 56 & 0,96 \\
07 & MGS & 27 & 36 & 52 & 54 & 56 & 0,96 \\
08 & RAT & 23 & 94 & 50 & 61 & 54 & 1,06 \\
\hline & & & & & & & \\
MÉDIA & 22 & 36,4 & 61 & 62 & 58 & 1,00 \\
DESV.PD.MÉDIO & 2,3 & 4,28 & 8,8 & 06 & 5,5 & 0,04 \\
\hline
\end{tabular}


ANEXO VII - Formação dos grupos segundo o equilibrio entre os processos da excıtação e os processos de ınibıção do sıstema nervoso. (cont)

TABELA 3 - Grupo composto por atletas atacantes de meio, com prevalència dos processos da inibição sobre os processos da excıtação do sıstema nervoso.

\begin{tabular}{|c|c|c|c|c|c|c|c|}
\hline$N^{\circ}$ & Nome & Idade & $E$ & FPE & FPI & $M$ & A-Traço \\
\hline 01 & MSM & 21 & 0.82 & 54 & 66 & 48 & 31 \\
\hline 02 & $\mathrm{HT}$ & 24 & 0.81 & 60 & 74 & 57 & 37 \\
\hline 03 & MP & 22 & 0.81 & 55 & 68 & 65 & 38 \\
\hline 04 & EC & 23 & 0.87 & 58 & 72 & 63 & 34 \\
\hline 05 & DT & 19 & 0.81 & 67 & 76 & 53 & 96 \\
\hline 06 & LA & 21 & 0.79 & 44 & 56 & 56 & 34 \\
\hline 07 & ECM & 21 & 0,77 & 48 & 62 & 46 & 33 \\
\hline 08 & $A C$ & 29 & 0.74 & 52 & 70 & 54 & 50 \\
\hline \multicolumn{2}{|c|}{ MÉDIA } & 24 & 0,03 & 53 & 69 & 55 & 379 \\
\hline \multicolumn{2}{|c|}{ DESV.PD MÉDIO } & 34 & 0,03 & 4,2 & 05 & 4,52 & 4.28 \\
\hline
\end{tabular}


ANEXO VII - Formação dos grupos segundo o equilibrio entre os processos da excitação e os processos de inibição do sistema nervoso. (cont.)

TABELA 4 - Grupo composto por atletas atacantes de ponta. com prevalència dos processos da excitação sobre os processos da inibıção do sıstema nervoso.

\begin{tabular}{llllllll}
\hline$N^{\circ}$ & Nome & Idade & $E$ & M & FPE & FPI & A-Traço \\
\hline 01 & SE & 19 & 2,06 & 74 & 70 & 34 & 40 \\
02 & DM & 19 & 1,69 & 48 & 44 & 26 & 43 \\
03 & LS & 19 & 1,58 & 70 & 76 & 48 & 35 \\
04 & AG & 19 & 1,53 & 72 & 46 & 30 & 48 \\
05 & CPQ & 30 & 1,46 & 56 & 70 & 48 & 38 \\
06 & DN & 19 & 1,45 & 68 & 58 & 40 & 57 \\
07 & MH & 20 & 1,41 & 66 & 55 & 39 & 34 \\
08 & MPC & 21 & 1,40 & 50 & 70 & 50 & 37 \\
\hline
\end{tabular}

$\begin{array}{lllllll}\text { MEDIA } & 20,7 & 1,54 & 62,6 & 61,4 & 40,5 & 42,8 \\ \text { DESV.PDMÉDIO } & 2,18 & 0,14 & 8,08 & 9,2 & 6,7 & 6,36\end{array}$


ANEXO VII - Formação dos grupos segundo o equilibrio entre os processos da excıtação e os processos de ınibıção do sıstema nervoso (cont)

TABELA 5 - Grupo composto por atletas atacantes de ponta com tıpo de sistema nervoso Equilibrado.

No Nome Idade $E$ M FPE FPI A-Traço

\begin{tabular}{lccccccc}
01 & MEH & 20 & 0.93 & 52 & 52 & 56 & 35 \\
02 & MVA & 18 & 0.91 & 79 & 64 & 70 & 44 \\
03 & FP & 19 & 0.90 & 70 & 76 & 84 & 30 \\
04 & NAB & 21 & 0.90 & 50 & 38 & 42 & 63 \\
05 & TS & 20 & 0.90 & 58 & 60 & 67 & 46 \\
O6 & DS & 23 & 0.89 & 52 & 57 & 64 & 31 \\
07 & JB & 27 & 0.89 & 42 & 54 & 61 & 98 \\
08 & EB & 22 & 0.88 & 60 & 46 & 52 & 37 \\
\hline MÉDIA & & 21 & 0,90 & 67.1 & 599 & 668 & 40.7 \\
DESV.PD MÉDIO & 1.4 & 0.01 & 1052 & 10.5 & 11,8 & 812 \\
\hline
\end{tabular}


ANEXO VII - Formação dos grupos segundo o equilibrio entre os processos da excitação e os processos de inibição do sıstema nervoso. (cont)

TABELA 6 - Grupo composto por atletas atacantes de ponta com prevaléncia dos processos da excitação sobre os processos da excitção do sistema nervoso.

\begin{tabular}{lccccccc}
\hline$N^{\circ}$ & Nome & Idade & $E$ & $M$ & FPE & FPI & A-Traço \\
\hline 01 & LP & 20 & 0,68 & 76 & 40 & 52 & 60 \\
02 & LV & 23 & 0.65 & 57 & 41 & 37 & 91 \\
03 & CC & 21 & 0.63 & 60 & 40 & 38 & 60 \\
04 & ICB & 20 & 0.63 & 54 & 42 & 34 & 58 \\
05 & FM & 20 & 0.67 & 72 & 47 & 44 & 60 \\
06 & AR & 20 & 0.61 & 76 & 40 & 46 & 46 \\
07 & SSO & 19 & 0.59 & 78 & 31 & 46 & 48 \\
08 & DRS & 18 & 0.58 & 48 & 49 & 28 & 60 \\
\hline MEDIA & & 20 & 0,59 & 64 & 45 & 28 & 40 \\
DESV.PD MÉDIO & 0.8 & 0.05 & 10 & 3,48 & 72 & 7.24 \\
\hline
\end{tabular}

FPE: Força dos Processos de Excitação do sistema nervoso dos individuos FPI: Força dos Processos de Inibição do sistema nervoso dos individuos 
ANEXO VII - Formação dos grupos segundo o equilibrıo entre os processos da excıtação e os processos de ınibıção do sıstema nervoso (cont)

M: Mobılidade do sıstema nervoso dos individuos

E: Equilibrıo entre os processos de Excıtação e Inibıção do sıstema nervoso dos individuos

A-Traço: Nivel de Ansiedade de Traço dos indıviduos 
ANEXO VIII - Defınição de Termos

a) Excitação - é a propriedade dos seres vivos É a resposta ativa do tecido excitável sobre alguma irritação ou ativação. Função básıca do sıstema nervoso e têm a capacidade de conduzır a excitação do setor em que ela apareceu até aos outros setores e as próximas células nervosas Com esta peculiaridade as células nervosas adquiriram a capacidade de transmitir os sinaıs de uma estrutura do organismo até as outras

b) Força dos Processos da Excitação - é a intensidade do desenvolvımento dos processos da Excitação

c) Inibição - é um processo ativo, indissoluvelmente, ligado com a excitação provocando retenção da atividade dos centros nervosos ou dos órgãos de trabalho.

d) Força dos Processos da Inibição - é a intensidade do desenvolvımento dos processos da Inibição.

e) Mobilidade - é uma das primárias propriedades do sistema nervoso que consıste na capacidade de reagir rapidamente às mudanças do ambiente

f) Equilibrio - é uma peculiaridade revelada através da proporção entre os processos da excitação e dos processos da inibição. (Petrovski, 1985)

G) Temperamento - é a combinação determinada e estável das peculiarıdades psicodinâmicas dos individuos, que se revelam em suas atıvidades e comportamento, compondo sua base orgânica ( Petrovski, 1985) 
ANEXO VIII - Definição de Termos. (cont.)

H) Ansiedade Traço - É uma predisposição geral da personalidade de um individuo para perceber situações como ameaçadoras ou não (Martens et al 1990). 